\title{
Country report for Kenya
}

Patricia Kameri-Mbote (lead author), Irene Kamunge (contributing author) \& James Kipkerebulit Yatich (contributing author)

\section{Introduction}

Soil has ecological, cultural, economic and political dimensions. ${ }^{1}$ It provides a wide range of natural habitats for living creatures; it supports diverse ecosystems ${ }^{2}$ of interdependent plant and animal life; and it is a source of livelihood for life forms great and small. Despite the recognition and acknowledgement of the critical functions of soil, there is no specific legal regime dealing with it. Owing to the wide range of activities related to environmental systems, soil protection tenets are dispersed across multiple laws and policies. They are found in laws dealing with land rights, land use, environmental and natural resource protection, and health, among others.

The protection of river courses and water bodies from pollution through to soil erosion has, for instance, given rise to different mechanisms, such as bench terraces, to ensure the integrity of the soil. In the public health realm, soil has been secured through protection from vermin harmful to human health. Since soil is not always the primary focus of these mechanisms, sustainable and sound soil management is not canvassed as there are different interests and competing soil uses to be balanced in these complex regimes. This calls for the development of bespoke soil policies, sound governance, and the monitoring of mechanisms to guide the utilisation and sustenance of soil for present and future generations.

This report examines soil protection measures contained in Kenya's laws, policies and programmes with a view to mapping out options for model legislation for sustainable soil management in Africa. It is important to point out at the outset that there is no specific legislation on sustainable management of soil in Kenya. We will discuss explicit or implicit tenets touching on soil protection, drawn from diverse laws addressing other issues. As a prelude to the discussion of legislation, policies and regulations, we describe a variety of relevant aspects of the body of land that makes up Kenya. This discussion covers demography, soil types, climate, rainfall patterns, governance, the economy, and the main drivers of soil degradation. We also look at soil 
protection in Kenya from a historical perspective, with a view to identifying the different narratives that have shaped soil protection in this country.

The country report for Kenya is structured as follows: Firstly, some background country information will be provided. This is followed by a discussion on the main drivers of soil degradation. Thereafter, we provide background on soil legislation in Kenya from a historical perspective and outline legislation on the main drivers of soil erosion before concluding by making recommendations for future legislation on soil.

Kenya, a former British colony, achieved self-rule in June 1963 and gained independence on 12 December 1963. It lies approximately between Latitudes $4^{\circ} \mathrm{N}$ and $4^{\circ} \mathrm{S}$ and Longitudes $33^{\circ} 83^{\prime} \mathrm{E}$ and $41^{\circ} 75.5^{\prime} \mathrm{E}$, straddling the Equator. ${ }^{3}$ Kenya shares borders with Uganda to the west, Tanzania to the south, Ethiopia in the north, South Sudan in the northwest, Somalia in the east and the Indian Ocean to the southeast. ${ }^{4}$ The country covers a total area of about $582,646 \mathrm{~km}^{2}$, of which $11,230 \mathrm{~km}^{2}(1.9 \%)$ are water bodies, leaving $571,416 \mathrm{~km}^{2}$ of land. However, some $84 \%$ of total land mass $\left(490,000 \mathrm{~km}^{2}\right)$ comprises arid and semi-arid lands, which are characterised by low, erratic rainfall, high evapotranspiration rates, poor soil fertility and few water resources. ${ }^{5}$

Topographically, the country may be divided into four distinct geographical and ecological regions or zones, with different patterns of land use: the coastal plain, the arid low plateau, the highlands and Lake Victoria basin. The rainfall patterns are extremely varied but generally follow these regions, with Lake Victoria basin receiving the heaviest and most consistent rainfall. ${ }^{6}$

While Kenya retains institutional and economic capacities that make it a pre-eminent country in the region, its historical role as the regional leader is under threat from its neighbours. Kenya needs to address internal challenges, repurpose its infrastructural projects, and focus on wider regional integration to address the rising competition. For a long time, Kenya was the largest and most dominant economy in Eastern Africa in terms of gross domestic product and socioeconomic development in the areas of poverty alleviation, literacy, healthcare, income, civil liberties and freedoms, infrastructure and industry, among others. However, Rwanda and Ethiopia have recently been chipping away at Kenya's dominance. Of particular concern for the country is the need to address corruption and taxation schemes, which have increased the cost of doing business and reduced investment attractiveness.

\footnotetext{
3 Government of Kenya (2016b: 21).

4 Ibid.

5 Ibid.

6 Ibid.: 25, 26.
} 
Kenya is a champion of regional integration, has been host to many refugees from nearby countries, and has played a key role in peace processes of neighbouring Sudan and Somalia. Refugee camps are located on marginal arid and semi-arid lands in the northern part of the country. This has however contributed to further land degradation in these areas.

Like other countries in the region, Kenya faces threats from terror groups. AlShabab, a ragtag militia which has set up base in neighbouring Somalia, remains the source of Kenya's greatest threat from terrorism and violent extremism. The majority of al-Shabaab recruits from Kenya come from borderlands or peripheral areas that have suffered generations of marginalisation. While terror attacks have over time spread to various parts of the country, Kenya's coastal counties have taken an interest in dealing specifically with violent counter extremism. This initiative seeks to ensure sustainable development in the region. Kwale County, which is among these counties, has a vibrant agricultural sector that is affected by terrorism through increased insecurity and displacement of people. The county has instituted measures to coordinate multi-stakeholder efforts and approaches to prevent, counter and remove radicalisation and violent extremism.

\subsection{Religion}

The main religions practised in Kenya include Christianity, Islam, Hinduism and traditional African religions. While Christian churches representing Catholicism and Protestantism have traditionally had wide application since their introduction through colonialism, Pentecostal churches and Islam have attracted more followers in the last couple of decades. This has chipped at the dominance of the traditional churches. Islam has gained ground at the expense of Christianity. Despite efforts of colonial rulers to suppress and eradicate African religions, it remains clear that there are still people who subscribe to traditional religious beliefs, though their number is unclear. These beliefs continue to have an impact on introduced religions and the practice thereof.

\subsection{Climatic conditions}

Kenya has a moderate tropical climate tempered by topographical relief, especially mountains like Mounts Kenya and Elgon, and the Aberdare and Mau ranges, as well as the movement of the Intertropical Convergence Zone (ITCZ). ${ }^{7}$ Large water bodies like Lake Victoria and the Indian Ocean affect the rainfall in Kenya. ${ }^{8}$ A relatively wet 
and narrow tropical belt lies along the Indian Ocean coast. ${ }^{9}$ Behind the coastline stretch large areas of arid and semi-arid lands. ${ }^{10}$ Kenya generally experiences two seasonal rainfall peaks, one of 'long rains' (March-May) and the other of 'short rains' (October-December) in most places. ${ }^{11}$ Generally, Kenya is a relatively dry country with mean annual rainfall estimated at $680 \mathrm{~mm}$ per year. But this rainfall is unevenly distributed over country on both spatial and temporal scales, varying from about $200 \mathrm{~mm}$ in the arid and semi-arid zones to over 2,000 mm in the humid zone. ${ }^{12}$ Generally, most of the country suffers from inadequate rainfall and erratic weather, characterised by recurrent droughts and, in some places, floods. ${ }^{13}$ These in turn affect the entire economy, which is highly dependent on rain-fed agriculture. ${ }^{14}$

\subsection{Population}

According to the census carried out in 2009, Kenya's population was 38.6 million. ${ }^{15}$ The 2019 census has placed the population at 47.6 million. ${ }^{16}$ The total population more than tripled between 1969 and 2009 from 10.9 million in $1969 .{ }^{17}$ The country's annual growth rate went down from $2.9 \%$ in $2009^{18}$ to $2.2 \%$ in $2019 .{ }^{19}$ The population of Kenya is concentrated in the central and western parts of the country. ${ }^{20}$ The most densely populated counties include Nairobi $(4,397,073)$, Kiambu $(2,417,735)$, Nakuru $(2,162,202)$, Kakamega $(1,867,579)$ and Bungoma $(1,670,570)$, while less populous counties include Lamu $(143,920)$, Isiolo $(268,002)$, Samburu $(310,327)$ and Taita Taveta $(340,671) .{ }^{21}$ As regards age, those under the age of 15 constitute $40 \%$ of the total population. ${ }^{22}$ Approximately $75 \%$ of the country's population lives within the medium to high potential agricultural areas (consisting of $20 \%$ of the land mass), while the rest of the population live in the vast arid and semi-arid lands. ${ }^{23}$

9 Ibid.

10 Ibid.

11 Ibid.

12 Ibid.

13 Ibid.

14 Ibid.

15 See https://www.knbs.or.ke/?p=5621, accessed 1 February 2021.

16 Government of Kenya (2019a).

17 Ibid: 5 .

18 See https://data.worldbank.org/indicator/SP.POP.GROW?locations=KE, accessed 1 February 2021.

19 Government of Kenya (2019a).

20 Ibid: 11.

21 Ibid.

22 Government of Kenya (2019b:12).

23 Government of Kenya (2019a: 11). 


\section{$2.4 \quad$ Literacy levels}

The 2015/2016 reveals that in the group of population aged 15 and above the proportion of literate population was $84.5 \%$ with a higher proportion of $93.2 \%$ in urban areas and a lower proportion in rural areas $(78.8 \%) .^{24}$

\subsection{The economy}

The economy of Kenya is anchored in agriculture, environment and natural resources, energy and manufacturing, construction, transport and storage, tourism, and information and communication technology. Agriculture, which is climate dependent, directly accounts for $26 \%$ of the gross domestic product (GDP) and another $27 \%$ indirectly through linkages with other sectors. ${ }^{25}$ The sector employs more than $40 \%$ of the total population and more than $70 \%$ of Kenya's rural people. ${ }^{26}$ The sector accounts for $65 \%$ of the export earnings, provides a livelihood (employment, income and food security needs) for more than $80 \%$ of the Kenyan population, and contributes to nutrition through production of safe, diverse and nutrient-dense foods ${ }^{27}$ The sector is also the main driver of the non-agricultural economy including manufacturing, providing inputs and markets for non-agricultural operations such as building and construction, transportation, tourism, and education and other social services. ${ }^{28}$ The reliance of the economy on agriculture has implications for soil management and regulation.

Real GDP is estimated to have expanded by $6.3 \%$ in 2018 compared to $4.9 \%$ in $2017 .{ }^{29}$ The growth was largely attributable to increased agricultural production, accelerated manufacturing activities, sustained growth in transportation, and vibrant service sector activities. ${ }^{30}$ Activities in the agriculture, forestry and fishing sectors were vibrant in 2018 mainly on account of favourable weather conditions that characterised the year under review. ${ }^{31}$ The sector's growth accelerated from a revised growth of $1.9 \%$ in 2017 to $6.4 \%$ in $2018 .{ }^{32}$ At the end of June 2018, the total stock of public debt stood at KSh4,537.6 billion, of which external debt accounted for $56.6 \%{ }^{33}$ The debt from multilateral agencies was KSh829.8 billion, ${ }^{34}$ and the stock of external bonds

24 Kenya National Bureau of Statistics (2018: 83).

25 See www.fao.org/kenya/fao-in-kenya/kenya-at-a-glance/en/, accessed 8 May 2019.

26 Ibid.

27 Ibid.

28 Ibid.

29 Kenya National Bureau of Statistics (2019: 1).

30 Ibid: 2 .

31 Ibid: 18.

32 Ibid.

33 Ibid: 1 .

34 Ibid: 80 . 
was KSh480.0 billion. In June 2018, the stock of Treasury bonds and Treasury bills accounted for $33.3 \%$ and $19.4 \%$ of the total debt standing at KSh1,511.9 billion and KSh878.6 billion respectively. ${ }^{35}$

\subsection{National debt}

Kenya has also borrowed a large sum over the last six years with the overall sovereign stock debt rising from a ratio of nominal debt to GDP of 48.4\% in 2013 to a high of around $59.9 \%$ of GDP by October $2019 .{ }^{36}$ This translates to an amount of debt of KSh1.89 trillion in June 2013, which has since risen to the KSh5.9 trillion mark by October 2019. ${ }^{37}$

\subsection{Kenya's political system and governance}

Kenya's sovereign power is located in the people of Kenya under the 2010 Constitution. ${ }^{38}$ It is exercised either directly or through democratically elected representatives at the national and county levels, ${ }^{39}$ following the devolved system of governance. Sovereign power under the Constitution is delegated to Parliament and legislative assemblies in the county governments; the National Executive and the executive structures in the county governments; and the Judiciary and independent tribunals. ${ }^{40}$ The governments at the national and county levels are distinct and interdependent and conduct their mutual relationships on the basis of consultation and cooperation. ${ }^{41}$

The National Executive consists of the President, Deputy President and the Cabinet. ${ }^{42}$ The President is the head of state and government, and is the Commander-inChief of the Kenya Defence Forces. ${ }^{43}$ The Cabinet comprises the President, the Deputy President, the Attorney General, and 14 to 22 cabinet secretaries. ${ }^{44}$ The President appoints the cabinet secretaries to address diverse sectors, but the National Assembly must approve the appointments. ${ }^{45}$ There are, for instance, cabinet secretaries who are responsible for the environment and land. Under the cabinet secretaries are chief

Ibid: $80-81$.

36 Herbling (2019).

37 Owino \& Mutua, (2019: 6).

38 Article 1(1).

39 Article 1(2).

40 Article 1(3).

41 Article 6(2).

42 Article 130(1).

43 Article 131(1).

44 Article 152 (1).

45 Article 152(2). 
administrative secretaries and principal secretaries tasked to perform specific functions under designated directorates. Parliament consists of the National Assembly and the Senate with 418 members including the speakers of the two Houses. ${ }^{46}$

The Constitution establishes 47 counties, each with its own government. ${ }^{47}$ A county government consists of a county assembly and a county executive. ${ }^{48}$ The county assembly is made up of members elected from different wards in the county. ${ }^{49}$ The executive authority of the county is vested in, and exercised by, a county executive committee. ${ }^{50}$ The county executive committee consists of the county governor, deputy county governor and members appointed by the county governor, with the approval of the county assembly, from among persons who are not members of the assembly. ${ }^{51}$ The county governor and the deputy county governor are the chief executive and deputy chief executive of the county, respectively. ${ }^{52}$ A county executive committee is responsible for implementing county legislation; implementing national legislation within the county to the extent that this is required; and managing and coordinating the functions of the county administration and its departments, among other functions. ${ }^{53}$ A county executive committee may prepare proposed legislation for consideration by the county assembly. ${ }^{54}$

The legislative authority of a county is vested in, and exercised by, its county assembly. ${ }^{55}$ A county assembly may make any laws that are necessary for, or incidental to, the effective performance of the functions and exercise of the powers of the county government under the Constitution. ${ }^{56}$ Counties have, for instance, legislated on climate change, quarrying, charcoal burning and land use. ${ }^{57} \mathrm{~A}$ county assembly, while respecting the principle of the separation of powers, may exercise oversight over the county executive committee and any other county executive organs. ${ }^{58}$ It may receive and approve plans and policies for the management and exploitation of the county's resources and the development and management of its infrastructure and institutions. ${ }^{59}$

Articles 93, 97 and 98.

Article 6(1).

Article 176(1).

Article 177.

Article 179(1).

Article 179(2).

Article 179(4).

Article 183(1).

Article 183(2).

Article 185(1).

Article 185(2).

57 See the examples of Makueni, Kericho and Kitui. It is worth noting that many of these legislations address collection of fees and not the unsustainability of the practices. Counties like Kitui have however banned charcoal burning.

59 Article 185(4). 


\subsection{Legislative authority}

Despite the preponderance of different soil types with different management and conservation requirements, Kenya's legal and policy framework on soil governance is largely subsumed in land law. Land law has historically focused on land rights - that is, who holds what interests in what land. Land use was only recently addressed in policy ${ }^{60}$ Accordingly, the law is applied in generic terms, often overlooking the specific requirements of diverse soil types in different parts of the country. As noted above, the Constitution establishes national and county governments as two levels of government with exclusive or concurrent jurisdiction. Until 2010, the National Assembly was the single source of legislation in Kenya. Currently, however, each of the 47 counties has a county assembly. Article 185 of the Constitution mandates the county assembly to make any laws that are necessary for, or incidental to, the effective performance of the functions and exercise of the powers of the county government.

Under the Fourth Schedule, the national government is responsible for development of environmental, land and agricultural policies, while the county governments are tasked with implementation of specific national government policies on natural resources and environmental conservation, including soil and water conservation.

Different parts of the country have different soils types. The protection of these soils therefore requires soil-specific protection measures. Given that the county assemblies can legislate on soil governance, they remain game changers in introducing county soil-specific legislation. In addition, it is expected that with devolved governance will enhance law enforcement and agricultural and soils extension services. As such, the county governments need to monitor soil fertility and the replenishing of nutrients closely. This will assist in reducing soil degradation and will cumulatively increase food production and healthy soils.

\subsection{Environmental dispute resolution}

The Constitution establishes an independent judiciary ${ }^{61}$ consisting of judges of the superior courts, magistrates, and other judicial officers and staff. ${ }^{62}$ The superior courts include the Supreme Court, the Court of Appeal, the High Court, the Environment and Land Court ${ }^{63}$ and the Employment and Labour Relations Court. ${ }^{64}$ The Chief Justice is the head of the Judiciary, and is appointed by the President on the recommendation of the Judicial Service Commission and subject to the approval of the National

60 National Land Policy 2009 and National Land use Policy 2017.

61 Article 160.

62 Article 161(1).

63 Odote (2013).

64 Article 161(1) and (2). 
Assembly. ${ }^{65}$ The Environment and Land Court is critical in ensuring access to justice in environmental matters. ${ }^{66}$ Article 160 of the Constitution of Kenya 2010 provides for the independence of the Judiciary, which means that judicial officers are insulated from interference from various quarters and individuals, including the executive. Some of the mechanisms through which judicial independence is upheld in Kenya include: security of tenure afforded to judicial officers and the restatement that they are not subject to the direction of any person in the conduct of their work; and good remuneration to ensure that judicial officers do not easily fall captive to economic interests. ${ }^{67}$ The Kenyan Judiciary has made significant strides in its quest to reform and become independent, a stark contrast to the pre-2010 constitution period when corruption claims were rife, and thus eroding the confidence and the institutional legitimacy of the Judiciary as a whole. ${ }^{68}$

It needs to be mentioned, however, that concerns still remain about the integrity of some judicial officers even at present. ${ }^{69}$ On the other hand, the independence of the Judiciary continues to be affected and assailed particularly by the executive arm of government at present, especially in relation to funding. Over the last two years, the Judiciary has only been allocated around half of the budget it requested..$^{70}$ For instance, the budget for the Judiciary in the year 2019 was reduced by half, prompting closure of the various tribunals in the country. ${ }^{71}$ There have also been some covert and even, on occasion, overt measures to tarnish the names and reputations of particular judges, especially those deemed to have been making decisions that were not in line with the executive's interests. These smear campaigns have largely been conducted on social media by bloggers through various hashtags. ${ }^{72}$ This then illustrates the challenges that face the courts in general and this potentially can have an impact on their work.

Notwithstanding this, the Judiciary through the courts has been operating and making decisions in disparate areas of law and has made progressive decisions in the environmental protection sphere. The Environment and Land Court (ELC) has a central role to play in so far as soil governance and conservation is concerned. The court is an important player as it adjudicates disputes over land, issues relating to environmental degradation and environmental protection, and is vested with powers to make various orders including those relating to environmental restoration and rehabilitation. Courts, for instance, have a role to play in giving meaning and effect to environmental rights, which are also human rights, enshrined under Article 42 of the Constitution in the

65 Article 166(1).

66 Odote (2013).

67 Article 160.

68 Shiundu (2018).

69 Uhuru for example refused to gazette judicial officers in 2019.

70 Namusyule \& Mueni (2018).

71 Ogemba \& Muthoni (2019).

72 See https://bit.ly/3d7B9aQ, accessed 1 November 2019. 
chapter on Bill of Rights. The Environment and Land Court has been rather bold in making pronouncements that have had the effect of ensuring environmental protection so as to enable the implementation of the constitutional provisions. To illustrate, in Patrick Musimba v National Land Commission \& 4 Others [2016] eKLR, which was a case relating to the power of the state to compulsorily acquire land, ELC had this to say on sustainability:

[T]he State under Article 69 of the Constitution is enjoined to ensure sustainable development. (See also the preamble to the Constitution). The State is also to ensure that every person has a right to a clean and healthy environment. However, physical development must also be allowed to foster to ensure that the other guaranteed rights and freedoms are also achieved. Such physical development must however be undertaken within a Constitutional and Statutory framework to ensure that the environment thrives and survives. It is for such reason that the Constitution provides for public participation in the management, protection and conservation of the environment. It is for the same reason too that the Environmental Management and Co-ordination Act (EMCA has laid out certain statutory safeguards to be observed when a person or the State initiates any physical development. At the core is the Environmental Impact Assessment and Study, which is undertaken under Section 58 of EMCA and the regulations thereunder. Under Regulation 17, the Environmental Impact Assessment Study must involve the public. The inhabitants of any area affected by a physical development must be given an opportunity to air their views on the effects of any such development. After the Environmental Impact Assessment Study report is compiled, the same report must be circulated to the affected persons.

In addition, the National Environment Tribunal, which is a judicial tribunal constituted under EMCA 1999 to adjudicate disputes over the issuance of environmental impact assessment (EIA) licences and other decisions of the National Environmental Management Authority (NEMA), recently stopped the intended construction of a mega-coal project in Lamu in the coastal area of Kenya on the grounds that a proper environmental assessment or audit had not been conducted. In particular, the Tribunal found that the environmental and social impact assessment was inadequate as there were no details on how much pollution from coal, dust and ash the plant would produce. It also stated that the public participation conducted was not sufficient because - though there were meetings held with the local community - appropriate information to enable them to make informed decisions was not made available to the community members. The case, Save Lamu \& 5 Others v National Environmental Management Authority (NEMA) \& Another [2019] eKLR, was a major win in terms of promoting public participation in environmental governance and was a classic case of the powerless citizenry being able to wrestle successfully with the elite in society. What this means is that the courts can be a useful avenue if public-spirited individuals are able to agitate and institute public interest litigation cases grounded in the progressive constitution.

The Environment and Land Court has since restated the minimum basis for adequate public participation in environmental matters in Mui Coal Basin Local Community \& 15 Others $v$ Permanent Secretary Ministry of Energy \& 17 Others, Constitutional Petition No. 305 of 2012 at paragraph 97:

From our analysis of the case law, international law and comparative law, we find that public participation in the area of environmental governance as implicated in this case, at a minimum, entails the following elements or principles: 
a. First, it is incumbent upon the government agency or public official involved to fashion a programme of public participation that accords with the nature of the subject matter. It is the government agency or Public Official who is to craft the modalities of public participation but in so doing the government agency or Public Official must take into account both the quantity and quality of the governed to participate in their own governance. Yet the government agency enjoys some considerable measure of discretion in fashioning those modalities.

$b$. Second, public participation calls for innovation and malleability depending on the nature of the subject matter, culture, logistical constraints, and so forth. In other words, no single regime or programme of public participation can be prescribed, and the Courts will not use any litmus test to determine if public participation has been achieved or not. The only test the Courts use is one of effectiveness. A variety of mechanisms may be used to achieve public participation.

c. Third, whatever programme of public participation is fashioned, it must include access to and dissemination of relevant information.

It is worth pointing out that the Constitution has made provision for alternative and traditional dispute resolution. In the case of land, the National Land Commission is tasked to promote the resolution of land disputes through traditional dispute resolution. This is especially important because community land comprises over $60 \%$ of Kenya's land. Consequently, this mode of dispute resolution has significant potential to have an impact on soil governance.

Agriculture - the art and business of soil cultivation, crop production and livestock rearing - is the backbone of the economy of Kenya, a country which was recently ranked as a low middle income economy and the fourth largest economy in sub-Saharan Africa. ${ }^{73}$ Its population has nearly doubled since 1989, while arable land - which is $10 \%$ of Kenya's land mass - continues to decline as thousands of hectares of highly productive agricultural farmland is converted into satellite cities with massive infrastructure developments in areas like Kiambu and Nakuru counties. ${ }^{74}$ Yet these developments, among other natural factors, continue to pile pressure on these finite, yet decreasing agricultural soils to meet food demands of the rising population.

Soil and environmental degeneration in Kenya have been on the rise. Natural factors are partly to blame, while a significant portion of the degradation is attributable to human activities. Climate change, urbanisation, soil erosion, overgrazing, over-cultivation, compaction, industrial activities, illegal land allocations, and encroachment of sensitive environmental areas continue to affect soil fertility negatively and to result in the loss of soil biodiversity. 
3.1 Kenya soil profile: Soil types, distribution and degradation vulnerability

Kenya has a wide range of soils owing to the variation in geology (parent material), terrain and climate. ${ }^{75}$ Soil resources vary from sandy to clayey, shallow to very deep, and low to high fertility ${ }^{76}$ However, most of these soils have serious problems such as salinity/sodicity, acidity, low fertility and poor drainage. According to the Food and Agriculture Organization (FAO) classification system, the country has 25 major soil types. ${ }^{77}$ However, in terms of geographic coverage, about 15 soil types dominate, namely Nitisols, Regosols, Cambisols, Luvisols, Solonetz, Ferralsols, Acrisols, Alisols, Fluvisols, Andosols, Arenosols, Calcisols, Lixisols, Planosols and Vertisols. ${ }^{78}$ About $59 \%$ of Kenya's soils have moderate to high fertility, meaning that they are theoretically suitable for growing crops. ${ }^{79}$ Among these, the major soils used in agriculture in Kenya include:

Nitisols occur in the highlands and on steep volcanic slopes, such as the central highlands of Kenya. For optimal agricultural production, nitisols need the use of manure and inorganic fertilizers. ${ }^{80}$ Nitisols often have high clay content of more than $35 \%$ and are the most productive agricultural soils found in Kenya. ${ }^{81}$ They are used intensely for plantation crops and food production. ${ }^{82}$ They have better chemical and physical properties than other tropical soils. These include good moisture-storage capacity and aeration; organic matter content; cation exchange capacity; and percentage base saturation range from low to high. ${ }^{83}$ Most Nitisols are acidic $(\mathrm{pH}<5.5)$ owing to the leaching of soluble bases.

As previously observed, the continued optimal productivity of these types of soil requires continuous replenishing of nutrients through manure and inorganic fertilizers. Accordingly, their health depends on the purity of inorganic fertilizers. Counterfeit, substandard chemicals, goods and fertilizers are nothing new in Kenya. In January 2019, top Kenya Bureau of Standards officials, the state corporation mandated to promote standardisation in industry and commerce, were arrested and charged for importation of substandard fertilizer which had a high content of mercury and other metals. ${ }^{84}$ Such dubious activities greatly affect the fertility and productivity of these soils. Andosols, young volcanic soils, occur in areas with steep slopes and high rainfall, are

Government of Kenya (2016b: 30).

Ibid.

Ibid.

Ibid.: $30-31$.

Ibid.: 32 .

Ibid.

Ibid.

Ibid.

Ibid.

84 Karanja (2019). 
highly susceptible to erosion. ${ }^{85}$ With over $1,000 \mathrm{~mm}$ of rainfall per year, Andosols are exposed to excessive leaching. ${ }^{86}$ They are porous, have a high water-storage capacity and a low bulk density, and are acidic (low $\mathrm{pH}$ ) owing to the high leaching tendency of soluble bases and high levels of aluminium (Al). ${ }^{87}$ These conditions favour P-fixation, making it no longer available to the plants. ${ }^{88}$ Andosols are mainly used for the cultivation of tea, pyrethrum and temperate crops, and for dairy farming. To improve production, liming and the use of fertilizers is necessary. ${ }^{89}$ The mapping of soil erosion in Kenya reveals that almost all areas in Kenya are vulnerable to soil erosion, particularly in arid and semi-arid areas. However, erosion is also prevalent in steep, wet soils along Mount Kenya and the Aberdare range, including some parts of Nyeri, Murang'a, Meru, Tharaka Nithi and Nyandarua counties, all of which are in a region predominantly known for high-potential soils..$^{90}$

Acrisols, alisols, lixisols and luvisols occur in the coffee zones in the sub-humid areas, on undulating to hilly topography. They show an increase of clay content in the subsoil (B horizon). The subsoil is often not very porous, impeding root spreading. ${ }^{91}$ They have a relatively low water-storage capacity, compared with Nitisols. Acrisols and Alisols in wet areas have a low $\mathrm{pH}$ (acid), $\mathrm{Al}$ and $\mathrm{Mn}$ toxicities, and low levels of nutrients and nutrient reserves. ${ }^{92}$ These soils have poor structure and need erosion control measures. Organic and inorganic fertilizers are needed to improve crop production. The soils respond well to fertilizers (especially N, P and K) and to the use of soil organic matter. ${ }^{93}$ The use of fertilizers in soils has implications for soil health. ${ }^{94}$

The vulnerability of these soils is increased with the prevalence of the combination of Nitisols and Andosols. This combination tends to be found in areas that are densely populated, a fact that puts pressure on these soils in the course of food production for local communities and the country. As a result, there is a high use of organic fertilizers and chemicals. Coffee and tea cultivation being cash cropping, results in these areas having significant industrial activities, which emit effluents and contribute to air pollution.

Planosols and vertisols occur on very gently undulating to flat topography, mostly in rice-growing areas such as Mwea in Kirinyaga County and Kano plains in Kisumu. ${ }^{95}$ They are found in semi-arid and sub-humid environments. Owing to the high clay

\footnotetext{
85 Government of Kenya (2016b: 32).

86 Ibid.

87 Ibid

88 Ibid

89 Ibid

90 KASLMP \& Ministry of Environment and Natural Resources (2016).

91 Government of Kenya (2016b: 32).

92 Ibid

93 Ibid

94 David \& Edwards (1982)

95 Government of Kenya (2016b: 32).
} 
content in the subsoil (higher than in the topsoil), this layer is impermeable in the B horizon, resulting in very slow and poor vertical and horizontal drainage. Vertisols are dark-coloured, strongly cracking clays, which are best used for irrigated paddy rice and other crops that can withstand temporary waterlogging. ${ }^{96}$

Planosols and Vertisols soils are vulnerable in predominantly two ways. First, their use, through irrigation activities requires a high input of inorganic fertilizers and other chemicals, which, if substandard, end up polluting the soils. Secondly, and more important, a shortage of water in these irrigation areas leads to the use of wastewater/effluent as an alternative to clean and suitable water. ${ }^{97}$

Ferralsols occur on gently undulating to undulating topography. ${ }^{98}$ They are very old, highly weathered and leached soils, and therefore have poor fertility, which is restricted to the topsoil, as the subsoil has a low cation exchange capacity. ${ }^{99}$ They are deficient in phosphorous $(\mathrm{P})$ and nitrogen $(\mathrm{N})$. Ferralsols are rich in aluminium (Al) and iron $(\mathrm{Fe})$. The nutrient reserves in these soils are easily disturbed by agricultural practices. ${ }^{100}$ Important management practices on these soils include the use of fertilizers (such as rock phosphate) and the maintenance of soil organic matter by using green manures, farmyard manures and mulching. ${ }^{101}$ Ferralsols have good physical properties including an excellent capacity to hold moisture and are used to grow annual crops. ${ }^{102}$

\subsection{The main drivers of soil degradation}

\subsubsection{Agriculture}

Agriculture is the backbone of the Kenyan economy and is practised on large, small and subsistence scales. Arable lands are fast turning into concrete jungles as a result of urbanisation. This has resulted in immense pressure on the remaining agricultural farmlands to produce enough food for the rising population. There is also increased mechanisation and increased use of technology and agricultural chemicals in production in the country. As already observed, there have been several instances of importation of substandard fertilizers and other agrochemicals into Kenya. These substandard agricultural chemicals lead to soil and water pollution. In irrigation schemes for instance, high soil contamination as a result of use of uncertified chemicals has been recorded in paddy rice production in some areas of the Mwea Irrigation Scheme.

96 Government of Kenya (2016b: 32-33).

97 Nyabonyi (2016).

98 Government of Kenya (2016b: 33).

99 Ibid.

100 Ibid.

101 Ibid.

102 Ibid. 
Despite agreement and recognition of the fact that extension services, if properly designed and implemented, improve agricultural productivity, the coverage of Kenya's agricultural extension system remains grossly inadequate. ${ }^{103}$ This has in turn led to poor and unbalanced soil nutrition. This is exacerbated by mono cropping and the blind use of agrochemicals and fertilizers without knowledge of soil nutrients.

The Third Medium Term Plan (2018-2022) of Kenya's Vision 2030 identifies low and declining soil fertility due to poor farming methods as one of the challenges facing the agricultural sector. ${ }^{104}$ Harmful agricultural practices include land clearing, overgrazing caused by large livestock herds, charcoal and wood extraction, cultivation on steep slopes, bush burning and soil nutrient mining. ${ }^{105}$ Unsustainable agricultural practices and poor soils necessitate the use of fertilizers to improve productivity, which negatively affect the quality of soils.

Agricultural expansion has escalated over the past 20 years as a consequence of population growth and attendant increased food needs. Limited land resources and over-reliance on land often lead to subdivisions of land into smaller pieces for inheritance purposes. ${ }^{106}$ These pressures on land have resulted in high nutrient outflows and the breakdown of former soil fertility maintenance strategies, such as bush fallow cultivation and the opening of new lands. ${ }^{107}$

Most of the agricultural activities in Kenya are subsistence in nature and the farmers are yet to embrace modern methods of food production. As such, practices such as the burning of vegetation cover as a way of cultivating virgin lands is still rampant. Vegetation cover burning leads to huge deposits of carbon on the soil. Most Kenyan farmers are smallholders in rural areas cultivating land parcels measuring two hectares or less. ${ }^{108}$ Many of these farmers cultivate on steep slopes and fragile soils, which are highly susceptible to erosion. The farmers depend on already degraded lands to meet their food requirements in a context of increasing demand for food and declining to stagnant agricultural productivity. ${ }^{109}$ This has resulted in rapid expansion of agricultural land and reduced rehabilitation of soil fertility through shortening of the uncultivated periods in extensive land use systems. ${ }^{110}$ Over-cultivation of the same land for many years leads to a hardpan, which reduces water infiltration, resulting in increased runoff, and hence erosion. ${ }^{111}$ The soils are degraded both physically and through nutrient loss, resulting in the decline of land productivity. ${ }^{112}$ It has for instance been

103 Muyanga \& Thomas (2006).

104 Government of Kenya (2018b: 45).

105 Government of Kenya (2016b: 67).

106 Ibid.: 53.

107 Ibid.

108 Ibid.: 75 .

109 Ibid.

110 Ibid.

111 Ibid.

112 Ibid. 
estimated that smallholder farming systems in the highlands of Kenya lose an equivalent of $112 \mathrm{~kg} \mathrm{~N}, 2.5 \mathrm{~kg} \mathrm{P}$ and $70 \mathrm{~kg} \mathrm{~K}$ owing to nutrient removals in the form of crop harvesting, leaching and soil erosion. ${ }^{113}$ Poor soils result in reduced above-ground productivity with the cascade effects of soil loss, fertility decline, and increased sediment loading in rivers, dams and lakes - further affecting water quality and occasioning loss of revenues. ${ }^{114}$

\subsubsection{Mining}

Kenya is a mineral-rich country with huge deposits of fluorspar in Kerio Valley, Elgeyo Marakwet County, gold in the western region counties, titanium in coastal areas, coal mining in eastern and coastal areas of the country, and soda ash at the coast and in Kajiado county. Other known minerals include manganese, iron ore, gypsum, diatomite, chromite, limestone, and silica sand. ${ }^{115}$ In anticipation of the discovery of new minerals and oil deposits, the country adopted its first ever mining policy in 2016 to enable the country to reap maximum benefits in future.

Heavy mining activities in mineral rich areas and quarrying have led to sizeable losses in biodiversity, increased soil erosion occurrences, contamination of soil due to huge deposits of chemicals used in excavation and mining, and contamination of surface and ground water. ${ }^{116}$ Mining and related activities also increase soil erodibility. Although EMCA provides for environmental protection, its enforcement and observance are not as effective as may be expected. For instance, it is a requirement that an EIA be carried out before embarking on any project likely to have a negative impact on the environment. In many cases, no such assessments are carried out in the extractive industry and, if carried out, they do not meet the legal threshold. For instance, in Cortec Mining Kenya Limited $v$ Cabinet Secretary Ministry of Mining \& 9 Others [2017] eKLR, a titanium extraction licence was cancelled on the grounds that an EIA had not been carried out despite mining having started. The establishment of the Lamu Coal Plant at the Kenyan coast was also halted by the National Environmental Tribunal in Save Lamu \& 5 Others $v$ National Environmental Management Authority (NEMA) \& Another [2019] eKLR for, among other reasons, failure to carry out EIAs to the required legal standards. These cases illustrate how environmental laws that could protect and conserve the environment, including soil, are disregarded.

113 Ibid.

114 Ibid.

115 Mining and Minerals Policy 2016, page 4.

116 David et al. (2016); Mutono (2016). 


\subsubsection{Industrial activities}

Kenya is an average industrialised economy serving both local and export markets in sub-Sahara Africa. Although the industries are mainly found in cities and major towns, a sizeable number of industries are found in agriculturally rich areas to cater for the value addition of agricultural produce. The current government has identified industrialisation as one of the major focus areas in the hope that it will create employment opportunities and boost the economy. ${ }^{117}$

Industrial activities produce effluent that is often deposited on soil. A study carried out in 2015 indicates that soils adjacent to industrial areas in Kenya contain persistent organic pollutants. Studies in areas with high industrial activities have also reported reduction in soil fertility and unbalanced soil nutrition. As previously observed, despite the existence of EMCA, which proscribes soil pollution and unlicenced discharge of treated wastes, industries often discharge effluent into rivers and onto soils against set standards and guidelines. For instance, in Benson Ambuti Adega \& 2 Others v Kibos Sugar and Allied Industries Limited \& 4 Others; Kenya Union of Sugar Plantation and Allied Workers (Interested Party) [2019] eKLR, Kibos Sugar Factory was found guilty of polluting the rivers and soils in its areas of operation. This company has on several occasions been closed down for effluent discharge in rivers and soils, with the discharges having had a negative impact on the environment and soil productivity. ${ }^{118}$

Enforcement of law on environmental protection has been somewhat scant, perhaps because of the compartmentalised governance structure. Under EMCA, the National Environment and Coordination Authority is the coordinator of environmental protection. It may lawfully direct lead agencies to take action for the purposes of environmental protection. ${ }^{19}$ However, the multiplicity of institutions that deal with environment has resulted in blame games and has not stemmed environmental pollution. Benson Ambuti Adega \& 2 Others v Kibos Sugar and Allied Industries Limited \& 4 Others; Kenya Union of Sugar Plantation and Allied Workers (Interested Party) [2019] eKLR points to the laxity of environmental protection institutions in taking action.

\subsubsection{Soil erosion}

Soil erosion is both an ecological and socioeconomic problem. ${ }^{120}$ The areas with the greatest risk include steep slopes; land usually bare before the onset of rains; soils with surface sealing problems that encourage runoff; bad tillage practices such as

117 Government of Kenya (2017a).

118 Allan (2019).

119 Environmental Management and Coordination Act, 1999, Section 3.

120 Land Use, the Case for National Land Use KLA, page 37. 
cultivating up and down slopes; exposure during periods of heavy rain and wind; and inappropriate land use and cultivation of marginal lands. ${ }^{121}$ The major erosion types are rill, gully and riverbank. ${ }^{122}$ Areas prone to gullies include bare land, animal tracks, faulty road drainage structures, and neglected rills and furrows. ${ }^{123}$ Up to $35 \%$ of the sediment load from 61 catchments in Kenya originates from roadside gullies. An equal amount is derived from footpaths and cattle tracks. ${ }^{124}$

Two processes cause soil erosion. ${ }^{125}$ The first is the loosening or detaching of the topsoil particles when large raindrops fall causing splash erosion, which occurs when vegetation cover has been removed and the soil surface is directly exposed to raindrop impact. ${ }^{126}$ If this occurs on sloping ground, the splashed soil particles wash downhill. ${ }^{127}$ Secondly, the transportation of such detached particles by flowing water causes rill erosion, which begins when shallow surface flow starts to concentrate in low spots on the soil surface. ${ }^{128}$

Soil erosion occurs when farming practices provide a medium for the two processes to take place. ${ }^{129}$ This happens through de-vegetation caused by shifting cultivation, clearance of land, overstocking and overgrazing. ${ }^{130}$ Other malpractices that promote soil loss include deep ploughing of land, lack of crop rotation, and ploughing and planting down the contour. ${ }^{131}$ In such areas with deep soils and high rainfall, landslide erosion occurs because rainwater infiltrates vertically into the soil up to the bedrock and then moves laterally along the bedrock, causing the soil at the outlet to slide. ${ }^{132}$

Loss of natural habitats has also reduced vegetation cover and exposed soils to extensive wind and soil erosion in many parts of the country. ${ }^{133}$ Soil erosion is a major factor in land degradation and has severe effects on soil functions, such as the soil's ability to act as a buffer and filter for pollutants, its role in the hydrological and nitrogen cycle, and its ability to provide habitats and support to diverse forms of life. Soil erosion also causes increased rates of siltation of dams and rivers and increased risk of flooding in rivers and estuaries. ${ }^{134}$ It also reduces the productivity of land, requiring farmers to apply more and more fertilizers and other chemicals to improve

121 Ibid.

122 Ibid.

123 Ibid.

124 Ibid.

125 Ibid.: 38 .

126 Ibid.

127 Ibid.

128 Ibid.

129 Ibid.

130 Ibid.

131 Ibid.

132 Ibid.

133 Government of Kenya (2016b: 65).

134 Ibid.: 56. 
productivity. The resultant excessive use of fertilizers and other chemicals contributes to further soil degradation and water pollution. ${ }^{135}$

On arid and semi-arid land, another cause of soil erosion by water is the opening up of saline and alkaline soils. ${ }^{136}$ A study of the erosivity index in Kenya shows that the highest risk of wind erosion is in humid and sub-humid climates on arid and semi-arid land ${ }^{137}$ where a high load of sand is suspended in the atmosphere. ${ }^{138}$ The highest incidence of wind erosion is most likely to occur in Marsabit, Moyale, Wajir and Garissa, ${ }^{139}$ while the lowest risk is around Makindu and Voi. ${ }^{140}$

Soil erosion is exacerbated by unsustainable land use and management practices. Agriculture is a major culprit, as it involves land clearing, overgrazing caused by large livestock herds, charcoal and wood extraction, cultivation on steep slopes, bush burning, and soil nutrient mining. ${ }^{141}$ The use of fertilizers to counter land productivity decline, caused by unsustainable agricultural practices and poor soils, negatively affects the quality of soils. Natural disturbances such as drought or flooding exacerbate the unsustainable human activities taking place in already fragile areas. Other human activities contributing to unsustainable land use include cultivation in water catchment areas; deforestation; poorly managed rangelands; encroachment of wetlands; and pollution from agricultural, commercial and industrial activities. ${ }^{142}$

The intersection between physical features and human behaviour produce land cover changes or alterations of the land surface, through conversion or modification, which leads to secondary environmental impacts such as soil erosion. ${ }^{143}$

\subsubsection{Unregulated urban and infrastructural development}

Over the past 20 years, Kenya's population has doubled. ${ }^{144}$ The increase in population has been accompanied by rapid rural to urban migration. The urban population increased from 5.4 million in 1999 to 12.2 million in 2009 and was projected to increase to 17.6 million in 2017 . This constitutes an urban population of $39 \%$ and an annual urban growth rate of $7.5 \% .{ }^{145}$ In addition, the creation of counties with autonomous county governments has led to increased urbanisation, at least in the 47-county

135 Ibid.: 58.

136 Land Use, the Case for National Land Use KLA, page 38.

137 Ibid.

138 Ibid.

139 Ibid.

140 Ibid.

141 Government of Kenya (2016b: 67).

142 Ibid.: 71.

143 National Land Use Policy, page 14.

144 Ministry of Land and Urban Planning (2017).

145 Ibid. 
headquarters. Unfortunately, planning laws have not kept up with the needed effective planning and management of urbanisation processes through provision of adequate and decent housing, sanitation and infrastructure. As previously observed, Kenya is now losing her rich agricultural lands to concrete jungles to supply housing for the rising urban population. This has led to loss of vegetation and forest cover and has put pressure on the remaining productive soils to cater for this population increase.

The government has continued to support the construction sector by formulating policies and programmes to improve infrastructure to spur economic growth. Programmes include the provision of decent but affordable housing; construction of the single-track standard gauge rail; the expansion and modernisation of the outer ring road; expansion of Ngong road; construction of Kenya's Western bypass, Dongo Kundu bypass and Nuno-Modogashe road; construction of Kisumu oil jetty; and construction of a new 20-inch diameter refined petroleum pipeline (Line 5) from Mombasa to Nairobi, with four new pump stations. ${ }^{146}$ These developments have further contributed to increased soil degradation. The laying of an oil pipeline that is not insulated through vast agricultural lands exposes the soil to contamination through leaks. Leaks have already sprung in Makueni in two places, exposing people and livestock to health and fire hazards, while polluting the water and soil.

\subsubsection{Climate change}

The world over, soil is a larger natural reservoir that stores carbon-containing chemical compounds accumulated over an indefinite period of time than the planet's biomass and atmosphere combined. The organic carbon sources in soil include microbes, fungi and invertebrates, as well as root matter and decomposing vegetation.

Reports indicate that Kenya is extremely vulnerable to climate change, with temperatures expected to rise by about $2.5^{\circ} \mathrm{C}$ by the year 2050 , while rainfall is expected to become more intense and less predictable. ${ }^{147}$ There are reported cases of increasing loss of soil organic carbon in Kenya, which is one of the principal signs of land degradation threatening sustainable development, biodiversity conservation, and mitigation and adaption to climate change.

Furthermore, over $70 \%$ of natural disasters in Kenya are related to extreme climate events, which are also key causal factors for some emergencies that lead to disasters. ${ }^{148}$ Kenya has, for instance, experienced effects of climate change such as prolonged droughts and floods in recent years. Large areas of Kenya are at risk of flooding, which 
results in soil erosion and loss of property and even lives. ${ }^{149}$ Floods have increasingly become a major threat to life, property and the environment - a factor associated with land degradation and climate change. ${ }^{150}$ All the six major drainage basins in Kenya experience different flood magnitudes with statistics indicating that in 1982 and 1985 floods in Nyanza and western Kenya affected about 14,000 people. ${ }^{151}$ Generally, the most flood-prone areas are in the counties of Garissa, Tana River, Lamu, Homa Bay, Siaya, Kisumu, Trans Nzoia, Uasin Gishu, Nyandarua and Busia. ${ }^{152}$

The worst floods were however experienced in the 1997/1998 El Niño flood, which covered the entire country and 1.5 million people were affected through displacement, loss of property and livelihoods. ${ }^{153}$ Other floods have been experienced in later years, including in 2012 when the long rains came late and caused heavy floods that resulted in displacements, loss of property and lives. ${ }^{154}$ Several rivers burst their banks and this can be attributed to reduced vegetation and thus poor rainfall infiltration, resulting in flash floods and soil erosion.

Kenya has suffered periodic droughts throughout its recorded history. The magnitude and severity of these droughts have increased over the years. The areas prone to drought include the arid and semi-arid lands, which are hot and generally receive less rainfall. For instance, serious droughts were recorded in 1972, 1974/75, 1977, 1980, 1982 , 1983/84, 1991/92, 1995/96, 1999/2000, 2004, 2006, 2009 and 2010/2011. ${ }^{155}$ The average incidence of serious drought has increased from around seven serious droughts during the period 1980-1990 to 10 between 1991 and 2003, with drought occurring every two years in the last decade. Droughts destroy vegetation, making land more vulnerable to erosion by wind and water. ${ }^{156}$

\subsubsection{Brownfield sites}

Brownfield sites are areas of land that are underutilised or abandoned as a result of actual or perceived contamination associated with previous activities for which they were used but have the potential for redevelopment or reuse. Some brownfield sites with perceived or real contamination - may have minimal physical constraints, may already have infrastructure, and may be located in desirable areas. ${ }^{157}$ In Kenya,

149 Ibid.: 62.

150 Ibid.

151 Ibid.

152 Ibid.

153 Ibid.

154 Ibid.

155 Ibid.: 64.

156 Ibid.

157 Kazungu et al. (2011). 
industrial sites, abandoned owing to relocation of industries to other places like Athi River, have land-cover change problems that require concerted redevelopment plans. ${ }^{158}$

\subsection{Other threats to soil}

\subsubsection{Topographic features}

Kenya has a varied topography with steeply sloping mountains, hills and highlands that render the country highly susceptible to soil erosion. These steep slopes on mountainous and hilly countryside encourage excessive water runoff, leading to land degradation. ${ }^{159}$ For instance, it has been recorded that in the upper Tana River sub-catchments of Thika and Chania, at least $66 \%$ of the farmers cultivate very steep slopes, which suffer excessive runoff. ${ }^{160}$ Earlier studies reported soil loss amounting to 247 tons per hectare per year on steep slopes of the high-potential areas in the Central Highlands, while on the steep agricultural areas of Taita Taveta up to $50 \%$ of agricultural lands suffered interill, rill and gully erosion. ${ }^{161}$

\subsubsection{Soil contamination}

The use of chemicals, fertilizers and fungicides has poisoned and compacted the soils. ${ }^{162}$ Fertilizer is the dominant farm input in Kenya, averaging 275,270 metric tons per year. ${ }^{163}$ Chemical discharges from industries and other urban waste contribute to further degradation of the soil. In a study on the concentration distribution and toxicological assessment of eight heavy metals, namely lead $(\mathrm{Pb})$, cadmium $(\mathrm{Cd})$, copper $(\mathrm{Cu})$, chromium $(\mathrm{Cr})$, nickel $(\mathrm{Ni})$, mercury $(\mathrm{Hg})$, arsenic $(\mathrm{As})$, and zinc $(\mathrm{Zn})$, in agricultural soils in Kenya, the results showed mean concentrations of $\mathrm{Zn}, \mathrm{Pb}, \mathrm{Cr}, \mathrm{Cu}$, As, $\mathrm{Ni}, \mathrm{Hg}$, and $\mathrm{Cd}$ as $247.39,26.87,59.69,88.59,8.93,12.56,8.06$, and $0.42 \mathrm{mg} / \mathrm{kg}-1$, respectively. These values were close to the toxicity threshold limit of United States Environmental Protection Agency (USEPA) standard values of agricultural soils, indicating potential toxicological risk to the food chain. ${ }^{164}$ Intensification of human

158 Ibid.

159 Government of Kenya (2016b: 60).

160 Ibid.

161 Ibid.

162 Land Use, the Case for National Land Use KLA, 43.

163 Ibid.

164 Occurrences and toxicological risk assessment of eight heavy metals in agricultural soils from Kenya, Eastern Africa. 
agricultural activities, growing industrialisation, and rapid urbanisation largely influenced the concentration levels of heavy metals in Kenya's soils. Moreover, the lack of agricultural normalisation management and poor enforcement of environmental laws and regulations further intensified the widespread pollution of agricultural soils.

Apart from agriculture, mining is also a driver of soil degradation through contamination. High mercury contents have been found in soil in the Migori-Transmara gold mining areas. ${ }^{165}$

\subsubsection{Soil compaction}

In Kenya, soil compaction is a major problem in areas with high livestock densities, and especially on denuded dry areas around watering points. ${ }^{166}$ Here, excessive trampling by livestock and wildlife compacts the soil, reducing its infiltration capacity and leading to high runoff flows, soil erosion and even gullying. ${ }^{167}$

\subsubsection{Salinity and sodicity}

Salinity and sodicity problems are common in the arid and semi-arid lands where soils are naturally formed under the prevailing climatic conditions and owing to high rates of evapotranspiration and lack of leaching water. ${ }^{168}$ About $40 \%$ or 25 million hectares of the land of Kenya is covered with soils that have salinity and/or sodicity problems. ${ }^{169}$

\subsubsection{Soil erodibility}

Kenya's soils have high erodibility (a natural property of soil), based on soil texture, profile depth, mineralogical composition and structure. Soil erodibility is also influenced by human activities, especially the addition or removal or organic matter. ${ }^{170}$ Fragile, easily damaged soils located along steep slopes are often associated with soil erosion, if vegetation cover is poor. ${ }^{171}$

165 Impact of gold mining associated with mercury contamination in soil, biota sediments and tailings in Kenya.

166 Government of Kenya (2016b: 66).

167 Ibid.: 67.

168 Ibid.: 68.

169 Ibid.: 66.

170 Ibid.: 65 .

171 Ibid. 


\subsubsection{Poor rangeland management}

Rangelands cover about $70 \%$ of the total area of Kenya, and are thus of utmost economic importance. ${ }^{172}$ Most of the rangelands are in the arid and semi-arid lands where pastoralists and agro-pastoralists face competition from an increasing influx of farmers from the overcrowded higher-potential areas migrating into the dry lands. ${ }^{173}$ Rangeland degradation is manifested by the loss of vegetation cover and an increase in the proportion of bare soil surface. ${ }^{174}$ Loss of vegetation cover and increased erosion can be attributed to livestock overgrazing. ${ }^{175}$ Overgrazing predisposes soil to water and wind erosion. ${ }^{176}$ As pointed out above, excessive trampling by livestock and wildlife compacts the soil, reducing its infiltration capacity.

\subsubsection{Loss of forest cover}

Forest ecosystems are important in conservation of soil, water and biodiversity, as well as in moderating climate. ${ }^{177}$ Over the years, forest resources, including wildlife and water, in public and community forests have faced numerous threats arising from human activities, including charcoal burning, illegal logging, overgrazing, and human encroachment of forest areas. ${ }^{178}$ Kenya's forest cover has over the years been depleted at a rate of 5,000 hectares per annum. ${ }^{179}$ This has led to extensive soil erosion in areas such as Leroghi, Ndoto and Mount Nyiru forest reserves. ${ }^{180}$ It is encouraging to note that Kenya's forest cover recorded an estimated increase from $7.2 \%$ of the total land area in 2013 to $7.29 \%$ in $2017 .{ }^{181}$ The government has committed itself to increasing the tree cover to $10 \%$ by $2022 .{ }^{182}$

172 Ibid.: 76.

173 Ibid.

174 Ibid.

175 Ibid.

176 Hannam \& Boer (2004: 4).

177 National Environment Policy, 11.

178 Government of Kenya (2018c: 28).

179 Ibid: 5 .

180 Ibid.: $39-40$.

181 Government of Kenya (2018b: 85).

182 See https://bit.ly/3cumZ33, accessed 1 February 2021. 


\subsubsection{Biodiversity loss}

Biodiversity contributes to a wide variety of environmental services including conservation of fertile soils. Kenya has lost considerable biodiversity. ${ }^{183}$ The most serious drivers of biodiversity loss are land degradation; climate change; pollution; unsustainable harvesting of natural resources; unsustainable patterns of consumption and production; and introduction of invasive and alien species. ${ }^{184}$ The invasive alien species that constitute a major threat to biodiversity in Kenya include Prosopis juliflora (Mathenge), Eichornia crassipes (water hyacinth), and Lantana camara. ${ }^{185}$

\subsubsection{Poverty}

Poverty is one of the main drivers of soil degradation in Kenya. Poverty has forced the people to encroach on marginal lands and forests, burn charcoal and fetch firewood, which is leading to deforestation and land degradation.

\subsubsection{Encroachment of fresh water and wetland ecosystems}

Freshwater resources and wetlands form an important part of Kenya's natural resources. The supporting services of these ecosystems are important for soil formation and retention, as well as for nutrient cycling. The ecosystems also provide habitats for plant and animal species. Wetlands act as sponges, absorbing excess stormwater from heavy rainfalls, and thus providing flow regulation, flood control and prevention of soil erosion. ${ }^{186}$ Floodwater may be stored in the soils or retained as surface water, thus reducing floodwater volumes downstream. ${ }^{187}$ In addition, wetland vegetation slows down the flow of floodwater, resulting in silt and sediment retention and riverbank protection. ${ }^{188}$ Besides reduction of flooding events downstream, this also ensures that river flows are maintained for longer periods. ${ }^{189}$ Wetland vegetation also protects the soil from damage by strong waves and wind. ${ }^{190}$ Wetland ecosystems face numerous threats from human population pressure and land use changes. Some of them have been converted for agricultural use, settlements and commercial developments. ${ }^{191}$

183 National Environment Policy, 19.

184 Government of Kenya (2013a: 14).

185 Ibid: 25 .

186 National Wetlands Conservation and Management Policy (2014: 6).

187 Ibid.

188 Ibid.

189 Ibid.

190 Ibid.

191 National Environment Policy, 12. 
Other threats include pollution; sedimentation and over-exploitation of wetland resources; introduction of alien species; encroachment on riparian reserves; and adverse effects of climate variability. ${ }^{192}$ These have caused extensive degradation, reduction in water quality and quantity, and loss of freshwater and wetland ecosystem goods and services.

A number of illegal allocations of land around riparian sites were recorded in the Report of the Commission of Inquiry into the Illegal/Irregular Allocation of Public Land. ${ }^{193}$ The land affected by these allocations is around rivers, lakes and the ocean. Huge commercial, religious and community centres, like Nakumatt Ukay and the Visa Oshwal Centre off Ring Road, Westlands, are constructed on river and wetland systems without any regard for the adverse consequences for the ecosystems. ${ }^{194}$ Construction on river and wetland ecosystems has led to clearance of riparian vegetation, which is essential for reducing soil erosion. The Government of Kenya has embarked on reclaiming riparian land with several properties allegedly built on the riparian reserve already brought down.

\subsection{Key actors in soil degradation}

\subsubsection{Investors}

Local and international investors engaged in diverse activities, such as agriculture, mining, and infrastructure and housing development, contribute to soil degradation. It is therefore important to include such investors when framing interventions to stem soil degradation. These should include both incentives to elicit sustainable soil management and sanctions to discourage degrading activities.

\subsubsection{Government}

The national and county governments, as landowners with activities on land and as custodians of land under their jurisdiction, are key actors in soil degradation. Both national and county governments have roles to play in land use planning and allocation. They also have activities on land. Enlisting their leadership in stemming soil degradation is critical if soil degradation is to be addressed holistically.

192 National Environment Policy, 12 and 13.

193 Comission of Inquiry (2004).

194 Ibid.: 120. 


\subsubsection{Farmers}

As users of land, farmers on community and private land are actors in soil degradation. Initiatives to stem soil degradation should target farmers through education and extension services that address unsustainable land use practices and soil contamination through the use of chemicals. Enlisting the participation of large- and small-scale farmers is critical to ensuring that soil degradation is stemmed. Any soil law or policy that leaves out farmers excludes a large segment of actors capable of bringing about real change considering their ubiquity in soil-related activities.

\subsubsection{Pastoralists}

Pastoralists in arid and semi-arid lands contribute to soil degradation through unsustainable rangeland management and overstocking. Many soils in rangelands are degraded and soils in areas around watering points compacted. Education and extension services targeting these practices can greatly enhance soil health and overall ecosystem integrity. This would greatly benefit the users of these lands.

\subsection{Conclusion}

Soil degradation in a country like Kenya where soil and agriculture accounts for $24 \%$ of the country's gross domestic index has drastic consequences. The main drivers of soil degradation are agriculture, mining, unsustainable land use, urban sprawl, climate change, and soil erosion. Soil compaction, sodicity and erodibility, poverty, and loss of biodiversity are also contributors to soil degradation in Kenya. As a developing country, Kenya is witnessing massive development, rapid population increase, and industrialisation. The country must remain cognizant of the biological, natural and physical drivers of soil degradation and must introduce legislation and enforcement measures to address them. The introduction of devolution as a form of governance is a golden opportunity to introduce more specific soil legislation in the 47 counties.

\section{Background on soil legislation}

\subsection{Historical perspective}

The reasons for the establishment of Kenya as a British colony have been variously explained to include the strategic significance of the Suez Canal in 1869 and hence the River Nile, and the need for expansion of the British Empire to be able to ward off 
economic competition from the United States, Canada and the European powers. ${ }^{195}$ The legislation passed from the time of the declaration of a protectorate in 1895 to independence in 1963 facilitated the acquisition and consolidation of rights to vast tracts of land by settlers. ${ }^{196}$ Africans were moved to native reserves.

The law did not directly address soil conservation. However, the way in which, and the speed at which, colonial policies were implemented destabilised the structures of the local communities and centres of authority, and significantly disrupted the equilibrium between people and their physical environment. ${ }^{197}$ The increase in the population of Africans in the reserves without expansion of the land available for their occupation and use resulted in over-use and hence soil deterioration. A number of colonial policies and laws are relevant for soil governance.

Acquisition of land rights for settlers was mainly done through political processes that were followed by legal instruments giving the political acts the requisite binding force. Colonial land policy was thus not systematic. Decisions were made in the face of day-to-day problems whose resolution demanded swift actions. ${ }^{198}$ To facilitate the alienation of land, the Indian Lands Acquisition Act of 1894 was extended to the East African Protectorate in 1899. The effect of this was to vest the power of control and disposition over $-{ }^{199}$

waste and unoccupied land in the protectorates where there was no settled form of government and where land had not been appropriated either to the local sovereign or to individuals. Her Majesty might, if she pleased, declare them to be Crown lands or make grants of them to individuals in fee or for any term.

Pursuant to this, a need arose to define what "Crown lands" meant. The East Africa (Lands) Order-in-Council, 1901 defined Crown lands to mean "all public lands within the East Africa Protectorate, which for the time being are subject to the control of His Majesty by virtue of any Treaty, Convention, or Agreement, or of His Majesty's Protectorate, and all lands which have been or may hereafter be acquired by His Majesty". 200

While this provision solved the issue of acquisition of land for public purposes, land had to be acquired for private persons and the settlers were dissatisfied with the nature of rights that they had been able to secure thus far. ${ }^{201}$ Attempts by the incoming settlers to acquire land through purchase from the native people were frustrated by the lack of

195 Mungeam (1966); Wolff (1974).

196 Ibid.

197 See e.g. Lugard (1929) on the effects of colonialism on the institution of traditional chiefs in Kenya. See also Huxley (1935).

198 Kameri-Mbote (2002).

199 See Palley (1966: 82) quoting the Report of the Foreign Office FOCP 7403 No. 101.

200 See $\S 1$ of the East African Order-in-Council, 1901, passed at the Court of St. James on 8 August 1901.

201 For some time, the colonial officers considered themselves unable to grant anything more than temporary certificates of occupancy which the early settlers found unacceptable. 
capacity on the part of the natives to sell land, as the settlers would have wanted. This is a critical aspect of native land tenure that has implications on people's relationship with the land, soil and other resources on the land. To many of the natives, land was inalienable, and the allodium or paramount title vested in the entire community. ${ }^{202}$ This mode of holding land led to the general view of the colonial administration that Africans had no rights to land either as individuals or as groups. ${ }^{203}$ Their ways of relating with and using land were negated with terra nullius as the dominant assumption. This has had implications for Kenyan land law and policy as will become clear from the discussions below.

\subsection{Colonial laws, policies and plans}

\subsubsection{Crown Lands Ordinance, No. 21 of 1902}

The Crown Lands Ordinance, No. 21 of 1902 was passed because of increased pressure from the incoming settlers. It vested power in the commissioner to sell freeholds in Crown land to any purchaser in lots not exceeding 1,000 acres. ${ }^{204}$ These regulations conferred enormous discretionary power on the colonial authorities that had a virtually free hand to determine what was waste and unoccupied land. The tendency was to treat all native rights to land as temporary and only exercisable if the native was actually occupying the land. Such rights, Lord Haldane contended, could be extinguished by the action of a paramount power taking possession and assuming full control of a country. ${ }^{205}$ This view is significant when one considers the plight of nomadic pastoralist communities, such as the Maasai and the agricultural communities where people cultivated different pieces of land and practised shifting cultivation. These practices were coping and adaptation mechanisms for communities using the land and were based on their knowledge of the terrain.

By virtue of the 1902 ordinance, the Crown authorities could grant land, which included native settlements and villages. The ownership of these villages would be vested in the grantee once actual native occupancy ceased. These provisions effectively converted communally managed resources into open access ones, paving the

202 Bentsi-Enchill (1964).

203 See the case of Mulwa Gwanobi v Alidina Visram (1913) 5 K.L.R. 141 involving the sale of land by members of the Jibana tribe where the Court held that what the tribe members sold were rights to occupy and reap fruits from the land and not absolute rights as the purchaser would have had the Court believe. In the Judge's view, the members of the tribal community had only a right of occupancy and they could consequently not pass on by sale a right greater than the one of occupancy.

204 See $\S 4$ of the Crown Lands Ordinance 1902.

205 See Sobhuza II v Miller and others [1926] A.C. 518 at 525. 
way for actual settlement of the protectorate. ${ }^{206}$ The price and rent asked for the land was very low so as to attract many settlers since the colonial authorities did not perceive the natives as capable of developing as vibrant an economic state as they envisaged Kenya would become.

\subsubsection{Crown Lands Ordinance, 1915}

The Crown Lands Ordinance of 1915 declared all land within the protectorate to be Crown land whether or not the natives occupied such land or whether or not it was reserved for native occupation. ${ }^{207}$ The ordinance mandated the colonial authorities to grant 999-year leases though the settlers clamoured for perpetual leases. ${ }^{208}$ Chief Justice Barth's interpretation of the provisions of this ordinance in the case of Isaka Wainaina \& Another $v$ Murito wa Indagara \& Ors was to the effect that Africans were mere tenants at the will of the Crown, with no more than temporary occupancy rights to land. ${ }^{209}$ Section 54 of this ordinance gave powers to the governor to reserve any land for "the use and benefit of native tribes". ${ }^{210}$ Exercising this power the governor, in 1926, gazetted 24 African reserves. ${ }^{211}$ There was no security of tenure provided in the native reserves. ${ }^{212}$ The increase in population in the native reserves led to soil degradation. Dr Leakey's testimony to the Carter Commission of 1933 to the effect that the Kikuyu native reserves were congested bears this out. His opinion was that the Kikuyu would be faced with an identical need for land for subsistence and stock raising ${ }^{213}$ and suggested that their reserves be increased by an additional 2,000 square miles of land extracted from the forest reserve located to the north of the Kikuyu native reserves. ${ }^{214}$ However, no additional land was granted to the Kikuyu, prompting a protracted war for independence with land as the major point of contention. The undocumented consequence of the forceful taking of natives' land rights was its impact on land, soil and the health and management of land-based resources.

206 See, e.g. Bondi \& Mugabe (1996) arguing that environmental degradation manifest in regions under customary land tenure is largely due to interference in rural resource management by a "modernising" nation-state rather that the "inherent vices" of customary property relations. See also Gadgil (1989).

207 See $\S 5$ of the Crown Lands Ordinance, 18 May 1915.

208 See $\S 34$ of the Crown Lands Ordinance, 18 May 1915.

209 (1922-23) Kenya Law Reports Vol. IX 102.

210 Kakumu (1996).

211 Ibid: 30 .

212 Ibid.

213 Corray (1978).

214 Ibid. 


\subsubsection{Native Lands Trust Ordinance, 1938}

Section 65(1) of the Native Lands Trust Ordinance of $1938^{215}$ bestowed power on the governor to make rules on the following issues that were pertinent to the management of soils when it came to native reserves:

a) Controlling the occupation and use of native reserves for grazing and pasturing stock

b) Compulsorily reducing the number of stocks, flocks and herds in any native land units

c) Regulating the reconditioning of any native land unit and, for such purpose, prohibiting and regulating the occupation of any areas

d) Regulating generally the use and conservation of any area in the native reserves

e) Regulating the issue of licences in the native areas for cattle grazing rights and the removal of timber, forest produce, sand, limestone and other common minerals apart from surface salt

f) Protection of trees and forest produce on land, not within the meaning of the Forest Ordinance and for regulating the felling and removal of such trees or forest produce

\subsubsection{Agricultural Policy, 1944}

The Agricultural Policy of 1944 came in at the tail end of World War II. Food had become scarce as drought ravaged most African countries. ${ }^{216}$ This policy, borrowed from Humphrey Norman's radical proposals, such as that Africans exceeding the carrying capacity of land should be moved to new settlement areas that were not overly populated. ${ }^{217}$ The other proposal was that attention be given to new agricultural methods and drought-resistant crops. ${ }^{218}$ There was also a proposal for communal cultivation to increase cooperation in soil conservation. ${ }^{219}$ In 1945 , elders in Nyeri started a sixmonth trial care for their lands. ${ }^{220}$ Labourers, who were mostly women, were required to turn up two mornings a week to dig terraces on family and clan lands. ${ }^{221}$ This is said to have produced spectacular results. ${ }^{22}$ This move was however stopped in 1948 when Jomo Kenyatta gave a speech at Fort Hall during a Kenya African Union address, stating that women should not be compelled to work on the terraces. ${ }^{223}$ It is important to note, first, the communities' eagerness to care for their soils; second, the involvement

215 Native Lands Trust Lands Ordinance 1938, at kenyalaw.org/lex/rest//db/.../Amendment\%20Acts/No.\%2028\%20of\%201938.pdf, accessed 17 May 2019.

216 Thurston (1987).

217 Ibid.

218 Ibid.

219 Ibid.

220 Ibid.

221 Ibid.

222 Ibid.

223 Ibid. 
of women; and, third, political interference with soil conservation initiatives that did not take into account the value of such initiatives on the ground.

\subsubsection{African Courts Ordinance, 1951}

The African Courts Ordinance of 1951 stated that the courts should consist of elders appointed by the provincial commissioner, who would have jurisdiction over all Africans. ${ }^{224}$ Administrative officers, the district officer and the provincial commissioner supervised these courts. ${ }^{225}$ At this time, the Native Authority of the clans was recognised, and they were enabled to make rules and orders on matters vital to the welfare of the people, like soil conservation. The African courts dealt with the breach of these rules and orders. ${ }^{226}$

\subsubsection{Swynnerton Plan, 1954}

By 1940, there was a severe land shortage within the reserves and the Africans were demanding the restoration of stolen lands. In 1952, these demands culminated in the Mau Mau revolts predominantly led by the Kikuyu. These revolts awakened the colonial administration to the need for tenure reform. Having constructed African tenure systems as 'non-property' or open access, the colonial agronomic experts viewed the solution to the African land problem as one of tenure, namely the structure of access to the use of land in areas occupied by the natives. The existing tenure system was perceived as inimical to proper land use and agricultural development as it encouraged fragmentation of land, which cut down on returns from labour and time expended on the land and led to incessant disputes that were a disincentive to long-term capital investment. ${ }^{227}$ The African tenure system of inheritance, characterised by subdivision of land in native reserves, also resulted in reduced productivity due to soil leaching. ${ }^{228}$

The solution to the problem was conceived in terms of individualised title to land and intensified agriculture in African areas through technological improvements. It was hoped that this would increase production and divert the attention of the Africans from the settler occupied areas. ${ }^{229}$ A commission was set up to investigate African tenure systems and to make recommendations on ways of improving them and making them contribute to the economic development of the colony.

224 The African Courts Ordinance of 1951, Section 4.

225 Ibid.: Section 1(b).

226 Munro (1959).

227 See Swynnerton (1954).

228 Ibid.

229 Ibid. 
The Swynnerton Plan of 1954 recommended the consolidation of land holdings of families into one, followed by the adjudication of property rights to that land and the registration of individuals as absolute owners of land adjudicated as theirs. ${ }^{230}$ This was primarily an economic plan whose purpose was to increase productivity in the agricultural sector. Soil conservation was critical if intensified production was to be achieved. Small holdings were consolidated, and a typographical map of the area was drawn, accompanied by a soil conservation plan. ${ }^{231}$

The severity of soil erosion in Kenya was realised as early as the 1920s. In an attempt to arrest the situation, compulsory terracing schemes, such as the Muhiriga system discussed above, were introduced in the 1940s. ${ }^{232}$ These were unpopular because their benefits were unclear to the local people. Some techniques developed during this period were effective, but the fact that they were based on enforced communal work meant that soil conservation was bitterly resented by the local people. ${ }^{233}$ Many terraces fell into disrepair around the time of independence in the early $1960 \mathrm{~s} .{ }^{234} \mathrm{It}$ is instructive to note in this regard that the relative proportions of land that was terraced in Kangundo-Matungulu-Mbiuni agroecological zone 3 (high-potential land) and Masii in zone 4 (semi-arid upland) in 1961 were essentially the same as those of $1948 .{ }^{235}$

\subsection{Selected soil conservation initiatives in post-independence Kenya}

After independence, terracing was renewed and carried out voluntarily. Farmers began to construct terraces within a few years of opening new land, even in the newly settled areas of Makueni (drier, warmer and lower zone 4 and 5, settled after 1945), where average slopes were less steep. ${ }^{236}$ Unterraced arable land had been virtually eliminated in all three areas by 1978, with significant progress made between 1961 and 1978, when arable areas were growing rapidly as a result of the increasing population. ${ }^{237}$ Terrace construction continued in the 1980s, and by 1990, erosion on arable land was considered to be under control. The problem was, however, only beginning to be tackled on grazing land. ${ }^{238}$

The soil and water conservation campaign began in the $1970 \mathrm{~s}^{239}$ when people became increasingly concerned about the future of their farmlands and were therefore

230 See Osolo-Nasubo (1977).

231 Ibid.

232 Karuku \& International Network for Natural Sciences (2018: 123).

233 Ibid.

234 Ibid.

235 Ibid.

236 Ibid.: 124.

237 Ibid.

238 Ibid.

239 Ibid. 
receptive to advice and ready to participate in conservation activities. ${ }^{240}$ Erosion was worsening owing to the expanding cropped area, while spells of drought regularly affected yields, especially maize. ${ }^{241}$ Enforced conservation did not work in colonial times, but in the 1970 s people were ready to respond to the new campaign as they envisaged accrued benefits to their efforts. ${ }^{242}$ Awareness and community participation in decision-making, which were previously lacking, bore fruit. ${ }^{243}$

Several projects aimed at improving crop and livestock productivity were initiated. While these were not anchored in any national law or policy, they provided the basis for soil protection and must be canvassed in any discussion on soil protection in Kenya. Indeed, they may provide pointers to what works and what does not, as lessons in framing soil legislation.

\subsubsection{National Soil and Water Conservation Project}

The Government of Kenya and the Swedish International Development Agency jointly funded the National Soil and Water Conservation Project, which began in 1974 and ended in 1994. Its overall objective was to contribute to food security and to raise the standard of living of the rural population, through suitable conservation practices. ${ }^{244}$

The project was implemented in cropped fields where erosion had the most damaging effect on productivity and farmers' incomes and focused on improving the status of arable land. The main method used was the development of bench terraces using the fanya juu (literally do up) terracing technique over a period of time. Soil was thrown up the slope from a ditch to form an earth embankment or bund, with several terrace banks made across a field, on the contour. The land between the bunds levelled off gradually and the field developed the stepped characteristic of bench terraces. Soil and rainwater were conserved between the fanya juu bunds. ${ }^{245}$

The technical objective was two-fold: to keep rainfall where it fell, and to keep soil in the field. The end result was better growing conditions for the crop, both immediately, because of an increase in the amount of moisture available, and in the long term, because the soil was conserved. ${ }^{246}$ Each farm was surveyed to see whether it required a cut-off drain to protect it from surplus rainfall runoff. The cut-off drain was usually designed to hold all the runoff which flowed into it, and therefore it was sometimes

240 Ibid.

241 Ibid.

242 Ibid.

243 Ibid.

244 Mutisya et al. (2010: 8).

245 Ibid.

246 Ibid.: 9. 
known as an 'infiltration ditch'. ${ }^{247}$ The alignment of the terraces was surveyed along the contour using a simple line level. The spacing between the terraces depended on the slope of the land. Apart from terracing, other recommended activities, though on a smaller scale, were grass strips along the contour, contour ploughing, simple gully control measures, tree planting, riverbank protection and grazing control. ${ }^{248}$

In 1987, the project changed focus to the catchment approach through farmers' groups, and agroforestry was incorporated as an activity to enhance the soil and water conservation measures. Farmers were organised into groups in each catchment area. A catchment covered an area extending from the hilltop to the riverbank and consisted of either one or two villages sharing common hydrological watersheds and therefore requiring similar soil conservation measures. Each catchment had a committee and a given number of farmers (approximately 200). Individual farmers undertook soil conservation measures on their farms with regular guidance from the extension officers. Communal activities included wetlands management, riverbank protection, communal tree nursery establishment and management, gully erosion control, and the erection of gabions. A shifting catchment approach was adopted through which the project would concentrate activities in one catchment area for one year, then shift to another. Catchment residents were provided with farm tools such as shovels, hoes, pangas (machetes), mattocks, pickaxes, crowbars and wheelbarrows. They were also provided with free agroforestry tree seeds and seedlings, and polythene tubes. The items were given as demonstration materials and the farmers were expected to appreciate the need for these items and then purchase on their own thereafter. After one year, the catchment committee was expected to continue coordinating soil conservation activities. ${ }^{249}$

Regular evaluation of the project was carried out, and the results and recommendations were discussed in workshops where necessary adjustments were made in the project activities. The project was successful in developing simple extension messages, which farmers easily understood. However, the project was rated as poor because most of the community-based activities were not sustainable in the absence of free farm tools and inputs. ${ }^{250}$ The groups disintegrated. The soil and water conservation and group agroforestry activities collapsed after the end of donor support and the catchment committees stopped their coordination roles. ${ }^{251}$ 


\subsubsection{Permanent Presidential Commission on Soil Conservation and Afforestation}

Pursuant to Section 23 and 24 of the 1969 Constitution, the President had the prerogative to set up and abolish offices in the public interest. Through this power, President Moi set up the Permanent Presidential Commission on Soil Conservation and Afforestation in 1981. This was necessitated because the President felt that the bureaucratic machinery of the Ministry of Agriculture was not adequate to deal specifically with issues of soil conservation. ${ }^{252}$ The commission had an open-ended mandate to deal with soil conservation without requiring amendment of objectives. ${ }^{253}$ It focused its strategies on afforestation and soil conservation, and formulating appropriate policies. ${ }^{254}$ The commission also focused on public education and coordinated government functions dealing with soil conservation. ${ }^{255}$ One of the recognisable efforts of this commission was establishing presidential soil conservation sites throughout the country. In Machakos, for instance, there were three sites: Mwanyani site, which started in 1982; Uuni site in 1984; and Masinga site in $1985 .{ }^{256}$

During President Moi's tenure, different authorities were established and tasked with responsibilities, which included conserving and protecting soil. The authorities were established through acts of Parliament as shown below:

\begin{tabular}{|l|l|l|l|}
\hline Authority & Act of Parliament & $\begin{array}{l}\text { Section granting } \\
\text { mandate }\end{array}$ & Areas covered \\
\hline $\begin{array}{l}\text { Ewaso Ng'iro North } \\
\text { River Basin Develop- } \\
\text { ment Authority }\end{array}$ & $\begin{array}{l}\text { Ewaso Ng'iro North } \\
\text { River Basin Develop- } \\
\text { ment Authority Act }\end{array}$ & Section 8(g) & $\begin{array}{l}\text { Isiolo, Laikipia, Sam- } \\
\text { buru, Marsabit, Wajir, } \\
\text { Mandera, parts of } \\
\text { Nyandarua, Meru and } \\
\text { Nyeri. }\end{array}$ \\
\hline $\begin{array}{l}\text { Tana and Athi Rivers } \\
\text { Development Author- } \\
\text { ity }\end{array}$ & $\begin{array}{l}\text { Tana and Athi Rivers } \\
\text { Development Author- } \\
\text { ity Act }\end{array}$ & Section 8(j) & $\begin{array}{l}\text { Area bound by and } \\
\text { drained by Tana and } \\
\text { Athi River together } \\
\text { with its tributaries. }\end{array}$ \\
\hline $\begin{array}{l}\text { Lake Basin Develop- } \\
\text { ment Authority }\end{array}$ & $\begin{array}{l}\text { Lake Basin Develop- } \\
\text { ment Authority Act }\end{array}$ & Section 8(h) & $\begin{array}{l}\text { Lake Victoria and } \\
\text { Lake Kyoga catch- } \\
\text { ment areas }\end{array}$ \\
\hline $\begin{array}{l}\text { Ewaso Ng'iro South } \\
\text { River Basin Develop- } \\
\text { ment Authority }\end{array}$ & $\begin{array}{l}\text { Ewaso Ng'iro South } \\
\text { River Basin Develop- } \\
\text { ment Authority Act }\end{array}$ & Section 8(h) & $\begin{array}{l}\text { Ewaso Nyiro South } \\
\text { River basin and catch- } \\
\text { ment areas situated } \\
\text { within Narok, Kaji- } \\
\text { ado, Nyandarua and } \\
\text { Nakuru districts }\end{array}$ \\
\hline
\end{tabular}

252 Bragdon (1990).

253 Ibid.

254 Ibid.

255 Ibid.

256 Gichuki (1991). 
4.4 Types of conservation measure that have been used in Kenya over the years

\subsubsection{Terraces}

Levelled bench terraces and earth bunding on existing slopes are common earth structures in Kenya. Sometimes, and especially in the highlands, steps are constructed across hillsides and strips of crop residues are covered with soils dug from above. The resulting incorporation of organic matter increases soil fertility and enhances infiltration through macro porosity as well as increased water retention in soils. ${ }^{257}$ The fanya juu earth bunding system is now common in Kenya and is designed to trap runoff and suspend sediment. ${ }^{258}$ The challenge, however, is the high labour requirement in their construction and maintenance. ${ }^{259}$

A fanya chini (do down) is like a fanya juu, except that the soil is put on the lower side of the contour trench, not on the upslope side as in a fanya juu. Fanya chini are used to conserve soil and divert water. The resulting embankment can be used to grow fodder. ${ }^{260}$

\subsubsection{Conservation agriculture}

There are three major principles of conservation agriculture as practised in Kenya: minimal soil disturbance, permanent soil cover, and crop rotation. ${ }^{261}$ Soils under conservation agriculture tend to improve their soil organic matter content considerably after applying the technology for several years. ${ }^{262}$ Soil organic matter is the most important soil fertility and quality factor influencing other soil properties such as macro porosity, infiltration, water holding capacity, and soil structure. In conservation agriculture, only minimal or no soil tillage is applied, and it involves crop seeding without mechanical seedbed preparation and with minimal or no soil disturbance since the harvest of the previous crop. ${ }^{263}$

257 Karuku \& International Network for Natural Sciences (2018: 125).

258 Ibid.

259 Ibid.

260 Ibid.

261 Ibid.

262 Ibid.: 126.

263 Ibid. 


\subsubsection{Cover crop for soil fertility and erosion control}

Cover crops are beneficial in stabilisation of soil moisture and temperature; protection of soil during fallow periods; mobilisation and recycling of nutrients; improvement of soil structure and breaking compacted layers and hard pans; permitting rotation in a monoculture; controlling weeds and pests; and producing additional soil organic matter that improves soil structure. ${ }^{264}$ In Kenya smallholders grow velvet bean, hairy vetch (Vicia villosa) and sun hemp (Crotalaria juncea) as cover crops. ${ }^{265}$ Some cover crops have been shown to suppress weeds, reduce nematode loads, improve soil fertility, reduce water leaching, and control erosion. In a study at Matunda farm in Kenya, it was observed that velvet bean produced more biomass than other cover crop species. ${ }^{266}$

\subsubsection{Green manure}

Green manure consists of plants grown specifically to accumulate nutrients for the main crop. These plants penetrate the soil with their roots, deliver nutrients and support infiltration of water into the soil. ${ }^{267}$ The contribution of organic matter to the soil by means of such green manure crops is comparable to the addition of 23 to 33 Mgha-1 of farmyard manure. Leguminous plants, for instance, fix nitrogen $(\mathrm{N})$ from the air into the soil and this $\mathrm{N}$ enriches the soil and feeds plants in the area. ${ }^{268}$ An alternative to sowing a green manure crop in the field is to collect fresh plant material from elsewhere and to work it into the soil (biomass transfer), as is done in western Kenya. It was observed that trees and shrubs growing alongside crops in agroforestry systems could provide large quantities of green material which could be used as green manure. Tithonia diversifolia, for example, accumulates a high concentration of nutrients in its leafy biomass, which then mineralises very rapidly when incorporated in soil. Green leaf biomass of Tithonia diversifolia harvested in western Kenya is high in nutrients in the order of $3.5-4.0 \% \mathrm{~N} ; 0.35-0.38 \% \mathrm{P} ; 3.5-4.1 \% \mathrm{~K} ; 0.59 \% \mathrm{Ca}$ and $0.27 \% \mathrm{Mg}$ on a dry matter basis. ${ }^{269}$

264 Ibid.

265 Ibid.: 127.

266 Ibid.

267 Ibid.: 128.

268 Ibid.

269 Ibid. 


\subsubsection{Agroforestry}

Various agroforestry technologies have been applied in Kenya, such as a) fertilizer trees like Calliandra spp., Leucena leucocephala, and Terminalia brownii, among others, that when combined with inorganic fertilizers double or triple crop yields in degraded lands; b) fodder trees used in smallholder zero-grazing systems in ways that supplement or substitute commercial feeds; c) improved varieties of temperate and tropical fruits used to supplement household incomes and nutrition; d) medicinal trees used on farms and conserved in situ; and e) fast growing timber and fuel trees that can be grown in various niches on the farm and in commercial woodlots and plantations. ${ }^{270}$

\subsubsection{Hedges}

Hedges are used in Kenya to conserve soils on contours. A contour hedge is a horizontal strip of multipurpose trees or shrubs that are used to control soil erosion on sloping lands. ${ }^{271}$ Contour hedges control erosion by providing a physical barrier and also by increasing water infiltration through a leaf litter layer creating good soil structure. ${ }^{272}$ Over the long term, these hedges have resulted in the formation of terraces on the upper side of each hedge, which are an added advantage in soil and water conservation. ${ }^{273}$

\subsubsection{Improved fallows}

Improved fallows have been used in some areas, where land is left to rest (fallow) from cultivation and is enriched with leguminous plants to speed up soil fertility replenishment. In western Kenya, maize yields improved following fallows. Fallows increase the water infiltration capacity of soil and are capable of deep-root development. Fallows also reduce soil erosion, by maintaining a leafy canopy during dry seasons and more vigorous crop growth during rainy seasons. ${ }^{274}$ Communities practising shifting cultivation, as noted above, make use of fallow seasons.

270 Ibid.: 129.

271 Ibid.

272 Ibid.: 130.

273 Ibid.

274 Ibid. 


\subsubsection{Vegetation strips}

Vegetation strips are usually narrow grass strips grown across slopes. The grass acts as a barrier to runoff, thus encouraging deposition of sediments and eventually leading to terrace development. The commonly planted grasses in Kenyan degraded lands are Imperata cylindrica, Vetiveria zizanioides and Pennisetum purpureum. ${ }^{275}$

\subsubsection{Conservation and regeneration measures}

Conservation and regeneration measures such as area closure and rotational grazing management measures are often applied to grazing land in situations where uncontrolled use has led to degradation and where other measures simply do not work without a fundamental change in land management. Enclosures are used to protect land from grazing and thus allow regeneration of vegetation cover. Other measures include intensification of grazing land use where fodder crops are planted and used for cutand-carry feeding of livestock. ${ }^{276}$

\subsubsection{Contour farming}

Contour farming involves ploughing, planting and weeding along the contour, across the slope rather than up and down. Contour ridges are commonly used in arid and semiarid lands to harvest water, and in the humid, higher rainfall areas for growing potatoes. ${ }^{277}$ Research has however shown that contour lines can be destroyed by termites eating the trash and thus compromising the conservation agenda envisaged. To overcome this obstacle, grass barrier strips are planted with fodder grass, like Napier, or the contour is left with natural grass. ${ }^{278}$ These are effective soil conservation measures on soils that absorb water quickly, and on slopes as steep as $30 \% .{ }^{279}$

\subsubsection{Trash lines}

Trash lines made by laying crop residues, or trash, in lines along the contour have been shown to slow down runoff and trap eroded soil, eventually forming terraces. Apart from impeding runoff and enhancing infiltration, trash lines also increase soil organic

275 Ibid.

276 Ibid.: 131.

277 Ibid.: 132.

278 Ibid.

279 Ibid. 
matter content when incorporated into soil during ploughing; enhance soil macro porosity, water holding capacity and soil hydraulic conductivity; and improve soil fertility upon decomposition and mineralisation. Trash lines are extensively used in the Tharaka area of Meru in northern Kenya. ${ }^{280}$

\subsubsection{Cut-off drains, retention and infiltration ditches}

Cut-off drains are usually dug across a slope to intercept surface runoff and carry it safely to an outlet such as a canal or stream with minimal risk of exacerbating erosion. ${ }^{281}$ They are used to protect cultivated land, compounds and roads from uncontrolled runoff, and to divert water from gulley heads. ${ }^{282}$

Retention ditches are dug along a contour to catch and retain incoming runoff and hold it until it seeps into the ground. They are an alternative to cut-off drains when there is no nearby waterway into which to discharge the runoff. They are used to harvest water in semi-arid areas. ${ }^{283}$

\subsection{Conclusion}

The concerns about soil degradation in Kenya have been recorded since colonial times. Measures to stem soil erosion have been part and parcel of land use for agriculture for a long time. As demonstrated above, a raft of initiatives has been implemented to curb land degradation generally and soil erosion specifically. These initiatives and measures form a good basis for soil legislation. The implementation of legislation is also favoured by the fact that people have experienced the negative effects of land degradation over the years, particularly in agricultural landscapes that have become less productive. Loss of lives due floods and landslides in different parts of the country attributable to land degradation is also a compelling motivation for both the enactment of a soil specific law and its implementation.

\section{Legislation on the main drivers of soil degradation}

Kenya has a plural legal system whose law comprises the Constitution, which lists the sources of law to include international treaties that Kenya has ratified; religious and

280 Ibid.

281 Ibid.

282 Ibid.

283 Ibid. 
customary laws; acts of Parliament (National Assembly and Senate); and county laws. The operationalisation of many laws is usually done through subsidiary legislation in the form of regulations by the line ministries. For soil, these include ministries responsible for environment, mining and agriculture. The inclusion of religious and customary law as sources of law introduces rarely addressed bodies of norms for governing the environment and soil. In dealing with culture, ${ }^{284}$ the state is mandated by the Constitution to promote science ${ }^{285}$ and recognise the role of science and indigenous technologies in national development. It is also exhorted to protect and enhance intellectual property in, and indigenous knowledge of, biodiversity and the genetic resources of the communities. ${ }^{286}$

Kenya is also party to international treaties addressing soil. These include the United Nations Framework Convention on Climate Change; the United Nations Convention on Biological Diversity, whose Aichi Targets are particularly relevant for sustainable soil management; and the United Nations Convention to Combat Desertification (UNCCD). The Constitution of Kenya provides that "the general rules of international law" 287 and "any treaty or convention ratified by Kenya" 288 is to form part of the law of Kenya. The nature and extent of the application of international law, however, is not as clear-cut as would be expected in the light of these provisions. The ambiguity of the constitutional provisions ${ }^{289}$ and the hierarchy of legal norms in municipal legal systems make the application of these constitutional provisions complex. ${ }^{290}$ Most legal systems require some act of domestication to bring international law norms into the municipal law, usually through legislation. The implication is that ratification is not enough even where there are provisions for direct application. ${ }^{291}$ While Kenyan courts have used international law to come to decisions, the prevalent practice remains that of cascading international law norms into municipal law through national legislation. Kenya's framework environmental law has incorporated many of the international environmental law norms, as we will see below. Kenya is also implementing the United Nations Agenda 2030 and has a robust framework for tracking the achievement of the Sustainable Development Goals (SDGs), which have specific application to soil management. ${ }^{292}$

The Constitution and statutes discussed hereunder impliedly and explicitly regulate the conservation and management of soil in Kenya. This governance regime has to be considered within the context of a long history of the country's engagement and

284 Constitution of Kenya 2010, Article 11.

285 Ibid., Article 11(2)(a).

286 Ibid., Article 69(1)(c).

287 Ibid., Article 2(5).

288 Ibid., Article 2(6).

289 Wabwile (2013); Oduor (2014).

290 Kabau \& Njoroge (2011); Kabau \& Ambani (2013).

291 Kabau \& Ambani (2013); O'Connell (1960: 452).

292 SDG 15 is particularly relevant here. 
investment in soil conservation. The measures outlined above, which have been used for protecting the soil, should be integrated into the operative laws as they have been successfully applied over the years. The discussion below highlights laws and policies that can be used for soil protection. It is a matter of grave concern that the detailed measures used for soil conservation are not directly canvassed in these laws. This is a missed opportunity for ingraining soil protection measures in environmental, land and natural resource management laws, policies and guidelines.

\subsection{International instruments relevant to soil protection}

Kenya has signed and ratified various international treaties, policies and strategies, which have an impact on soil protection and conservation. While some of these international instruments may not have had the protection of soil as their aim, the import of their provisions in the respective territories is to affect the conservation and protection of soil. Below is an overview ${ }^{293}$ of the international instruments (laws, policies, strategies, action plans and declarations) that Kenya has ratified or adopted, and which have an impact on soil regulation in Kenya:

The United Nations Sustainable Development Goals, 2030; the Declaration on Environment and Development, Stockholm 1972; The World Heritage Convention, 1972, which Kenya adopted in 1991, which provides for protection of ecosystems and habitats of global scientific value; the Ramsar Convention on Wetlands, 1992; Agenda 21 on Environment and Development, Rio de Janeiro, 1992; the Convention on Biological Diversity, which Kenya ratified in 1994; the United Nations Convention to Combat Desertification, which Kenya ratified in 1997; the United Nations Framework Convention on Climate Change, which Kenya ratified in 1994; the Rotterdam Convention on the Prior Informed Consent Procedure for Certain Hazardous Chemicals and Pesticides in International Trade, 1998; the Millennium Declaration, 2000; the Johannesburg Declaration on Sustainable Development, 2002; the Cartagena Protocol on Biosafety to the Convention on Biological Diversity, 2000; and the Stockholm Convention on Persistent Organic Pollutants, which was ratified by Kenya in 2004. In the following section, the most relevant international law instruments will be highlighted in more detail in terms of national relevance.

293 Adapted and modified from: KASLMP \& Ministry of Environment and Natural Resources. 


\subsubsection{Convention on Biological Diversity}

Kenya is a party to the Convention on Biological Diversity (CBD), and is thus bound by the provisions of the treaty. ${ }^{294}$ The main objective of the convention is to ensure the conservation of biological diversity in all its various forms, given its importance for sustenance of life on Earth. It reaffirms the responsibility of states to conserve their biological diversity and utilise biological resources in a sustainable manner. Soil forms part of the biological resources whose protection is intended by the convention. Article 3 of the CBD states the guiding principle of the convention, which basically is that states have the sovereign right to exploit their own resources in accordance with their own environmental policies, while bearing the responsibility of ensuring that activities under their jurisdiction do not cause damage to the environment of other states. It follows that while a state may lawfully utilise the soil occurring within its own jurisdiction as a matter of sovereign right, it has a duty to prevent soil degradation.

For purposes of accountability, Article 23 of the convention provides that the Conference of the Parties (COP) has the mandate to review the implementation of the convention in the respective countries. Article 26 of the convention establishes a reporting mechanism and requires all contracting parties to present reports on measures which they have taken for the implementation of the provisions of this convention and their effectiveness in meeting the objectives of the convention to COP. Accordingly, Kenya as a signatory to the convention submits its reports to COP on the extent to which it is implementing the provisions of the convention. To implement the CBD at the national level, Kenya has developed national biodiversity action plans. The first National Biodiversity Action Plan was prepared in 2000. To ensure its effective implementation, various laws, policies and strategies have also been adopted.

\subsubsection{Strategic Plan for Biodiversity (2011-2020) and Aichi Biodiversity Targets} (2020)

Contracting parties to the CBD adopted a strategic plan for biodiversity in 2010 to run from 2011 to 2020. This plan was to guide the achievement of the objectives of the $\mathrm{CBD}$ for the subsequent decade. This was to bring an end to or mitigate the continued biodiversity loss and enhance benefits to the population. The plan included the 2020 Aichi Biodiversity Targets, which would act as an indicator of how much progress was being made towards achievement of the objectives of the CBD. The Aichi Targets comprise five main strategic goals, namely socioeconomic and institutional changes; reducing direct pressures on biodiversity and ecosystems; ensuring the flow of benefits

294 See http://kenyalaw.org/treaties/treaties/87/Convention-on-Biological-Diversity, accessed 10 October 2019. 
of biodiversity to people and especially to communities whose subsistence is tied to local ecosystem services; and developing conditions required to implement the strategic plan as well as to develop the knowledge base. When Kenya submitted its Fifth National Report to the CBD it noted that Kenya had not finalised all the measures it had been required to undertake. It had, however, committed to continuing to review and enact various laws and regulations aimed at ensuring the restoration and maintenance of ecosystems.

\subsubsection{United Nations Convention to Combat Desertification}

The United Nations Convention to Combat Desertification (UNCCD) is another international instrument ratified by Kenya and which is relevant for purposes of soil conservation and protection. The convention defines 'combating desertification' broadly to include activities which are part of the integrated development of land in arid, semiarid and dry sub-humid areas for sustainable development aimed at: (i) prevention and/or reduction of land degradation; (ii) rehabilitation of partly degraded land; and (iii) reclamation of desert land. ${ }^{295}$ The main concern of the convention is the prevention of soil degradation and the restoration of already degraded land. What is more, the convention defines land to include soil as part of the terrestrial bio-productive system. ${ }^{296}$ In addition, land degradation that is sought to be curbed by the convention includes soil erosion either by wind or water, deterioration of the chemical, biological and economic properties of soil; and the long-term loss of natural vegetation. Under Article 5 of the convention, some of the obligations of affected parties are to address the underlying causes of desertification and give due priority to actions to combat desertification. Further, Article 10 of the convention requires contracting parties to develop national action programmes whose effect is to identify factors contributing to desertification and practical measures necessary to combat desertification.

Kenya ratified the Convention to Combat Desertification on 24 June 1997. A major commitment on the part of signatories to the convention was to develop national action plans to effectively implement the provisions of the convention. Following the ratification of the convention, Kenya received financial support from the United Nations Development Programme/United Nations Sudano-Sahelian Office (UNDP/UNSO) to facilitate the development of the National Action Programme (NAP). ${ }^{297}$ There were various sensitisation efforts and initiatives among stakeholders including government institutions, research institutions, the private sector, non-governmental organisations, community-based organisations and local communities living in the dry lands of the

295 Article 1b.

296 Article 1e.

297 Government of Kenya (2002). 
country. ${ }^{298}$ Information and data gathered during the sensitisation forums were analysed to help in the development of NAP. ${ }^{299}$ There was also support offered to local communities through the various community-based initiatives seeking to combat desertification, on a pilot basis, with a view to teaching the communities how to better manage local natural resources, enhance food security, and form partnerships with local communities. ${ }^{300}$ Workshops were then held at both local and national levels for stakeholders to deliberate and make recommendations on NAP.

According to NAP published in 2002, ${ }^{301}$ there were various constraints that stood in the way of efforts to combat desertification. These constraints included a sectoral approach that was adopted to programming; low and uncoordinated funding; frequent shifts of the mandate from one institution to another; inadequate legal, policy and regulatory frameworks; inadequate involvement of local communities in programming and decision-making; inadequate capacity for implementation, monitoring and evaluation; and inadequate access to production resources by local communities. ${ }^{302}$ Some of the recommendations that came out of NAP include circulation and sensitisation of people on the contents of NAP; development of many viable projects and programmes geared towards implementation of NAP; mobilisation of resources from all possible sources necessary to implement NAP; ensuring that there are mechanisms for integrating NAP into national development processes including budgeting; and integrating NAP into regional and sub-regional programmes. ${ }^{303}$

According to a study conducted by the United Nations Development Programme on efforts to implement the CCD (Convention to Combat Desertification) in Kenya's dry lands ${ }^{304}$ and published in $2013,{ }^{305}$ there are a variety of emerging lessons that may be gleaned and which for our purposes can be useful when considering future soil legislation. Some of the lessons drawn from the study are that improvement of livelihood and environmental management reinforce each other and that efforts to improve the former led to the improvement of the latter with the implication that efforts to reduce land degradation can be augmented by improving the economic position of the vulnerable, who then find little reason to further degrade land in search of a livelihood; participatory processes through an integrated approach whereby local communities are engaged by policymakers and development partners leads to better outcomes; local communities through community-based organisations have rich indigenous knowledge that they employed through 'traditional best practices' to avoid land

298 Ibid.

299 Ibid.

300 Ibid.: 4 .

301 Ibid.

302 Ibid.

303 Ibid.: 55.

304 The study covered parts of Turkana, Baringo, Narok, Taveta and Malindi.

$305 \operatorname{UNDP}(2013)$. 
degradation and soil erosion; continuous monitoring of initiatives leads to better outcomes; and practices that took into account the sociocultural perspectives of the local community tended to generate better results. ${ }^{306}$

Kenya as a country has tried to implement the various provisions of the CCD in a bid to prevent land degradation and combat desertification in the process. For instance, Kenya has since partnered with Japan International Cooperation Agency, Senegal and the CCD to launch what is now known as the African Initiative for Combating Desertification and Resilience to Climate Change in Sahel and the Horn of Africa. ${ }^{307}$ In addition, Kenya is also undertaking a programme that seeks to promote the growing of drought-resistant trees known as Melia volkensii, which is to increase forest cover and therefore reduce soil erosion and land degradation, particularly in the vast dry lands within the country. ${ }^{308}$ Furthermore, Kenya hosted the $15^{\text {th }}$ Session of the Committee for the Review of the Implementation of the Convention, which is a subsidiary body of the UNCDD charged with tracking the implementation of the convention by state parties in October 2016. ${ }^{309}$ In this session conference, Kenya intimated that it had a month before (in September 2016) launched an ambitious land restoration programme of massive pieces of land by the year $2030 .{ }^{310}$

\subsubsection{Land degradation-neutrality}

Land degradation neutrality (LDN) was defined in the 12th Session of the Conference of Parties to the UNCCD as "a state whereby the amount and quality of land resources necessary to support ecosystem functions and services and enhance food security remain stable or increase within specified temporal and spatial scales and ecosystems." ${ }^{11}$ As a concept, LDN was formulated so as to encourage a good mix of measures that had the effect of reducing, avoiding or even altogether reversing land degradation so as to achieve a state of healthy land or soil. ${ }^{312}$ At the core of LDN, then, are sustainable land management practices and better land use planning that takes care of the economic needs of both the present and future generations. ${ }^{313}$

LDN is a scientific conceptual framework within the UNCCD that seeks to ensure that avoidance of land degradation is integrated into planning processes and is supported by an enabling policy environment. ${ }^{314}$ Decisions with respect to LDN can be

306 Ibid.: $29-35$.

307 See http://www.environment.go.ke/?p=2874, accessed 26 October 2019.

308 Ibid.

309 Ibid.

310 Ibid.

311 UNCCD (2016).

312 Ibid.

313 Ibid.

314 Gichenje et al. (2019). 
coordinated through the mechanism of land use planning, which is regulated by a separate and distinct legal regime in Kenya. ${ }^{315}$ While there is no piece of legislation that expressly provides for LDN in Kenya, there are a number of laws and policies that either directly or indirectly affect the use of land particularly in the rural context, and which then indirectly may be said to be relevant in the implementation of LDN. It is to these policies and laws that we now devote our attention.

First, the Constitution provides for the right to a clean and healthy environment, including the right to have the environment protected for the benefit of present and future generations; and also has sustainability as one of the key principles of land policy. ${ }^{316}$ Chapter five of the Constitution, which is basically devoted to land and environment, provides various principles, including the sustainable use and management of the environment and the sound conservation and protection of ecologically sensitive areas. Land generally, including soil, forms part of the environment and there is thus a constitutional imperative to ensure that the soil is both clean and healthy in a manner that enables it to sustain agricultural productivity. This vision of the environment, articulated in the Constitution, certainly cascades and informs all other policy and legal instruments relating to every sector of the economy and society. On the other hand, the constitutional provision that requires the increase of tree cover to at least $10 \%$ of the whole total land mass seeks to reduce or reverse the effects of land degradation that have occurred in the past on account of mass deforestation, and thus fits in well as a measure aimed towards achieving LDN.

The Environment Management and Coordination Act of 1999 (as amended to reflect the Constitution of Kenya 2010), which is the overarching statute with respect to matters relating to environmental management, provides for protection and conservation of the environment, including soil at Part V of the Act. The Act also calls for afforestation and reforestation practices, especially for the maintenance of mountain ecosystems, hilltops and hill slopes.

Other statutes that have provisions relating to soil conservation, and thus form a legal basis for the implementation of LDN, are the Agriculture and Food Authority Act of 2015, which prescribes the preparation of guidelines for purposes of conservation of soil or the prevention of adverse effects of soil erosion on land; and the Community Land Act of 2016, which allows for the making of rules and by-laws to guide the conservation and management of land by registered communities.

In addition, the National Environment Policy calls for the development of the National Soil Conservation Policy, which has yet to be done. The National Land Use Policy of 2017 calls for the strengthening of the regulatory and enforcement agencies to ensure conservation of the environment and proscribes settlement and the undertaking of other activities, such as farming on ecologically sensitive areas. The National

315 Ibid.

316 Constitution of Kenya, Articles 42 and 60. 
Spatial Plan ${ }^{317}$ contains various policy statements, such as the development of an integrated land-use master plan for arid and semi-arid lands; the need to strictly regulate the subdivision of land in high potential agricultural lands; and the preparation of integrated management plans for environmentally sensitive areas, for example forests, mountains and wetlands. The National Policy for the Sustainable Development of Northern Kenya and other Arid Lands ${ }^{318}$ provides for the strengthening of research and extension systems that promote soil and water conservation, agroforestry and organic farming.

There are indeed other legal provisions that seek to offset the effect of land degradation and, as such, form part of the implementation matrix of LDN. For instance, the Environmental Management and Co-ordination Act of 1999 (EMCA) provides for environmental restoration orders, which may be given by NEMA or ELC, requiring a person who has given rise to land degradation or environmental damage to remedy such damage. There are virtually similar provisions in the Forest Management and Conservation Act of 2016 and the Wildlife Management and Conservation Act of 2013, both of which contain restoration orders or clauses with respect to mining and quarrying, which are permitted activities within forests and national parks.

Even at the county level, for instance, some county governments, such as those governing areas which suffer the most significant effects of land degradation, have taken legislative and policy measures. By way of illustration, the Makueni County Assembly passed the Makueni County Sand Conservation and Utilisation Act of 2015, which contains provisions seeking to promote the sustainable use of sand resources through afforestation and building of dams and gabions. These legal measures have the effect of reducing or reversing land degradation in the area and thus fit as LDN implementation measures.

In our view therefore, while there is no particular legislation that specifically speaks to LDN, there are various laws, policies, strategies and action plans, both at the national level and the county level, that contain provisions that advance LDN. This points to the need for policy coherence on issues of land degradation through the development and enactment of a soil conservation policy and law.

\subsection{Regional policies and instruments}

At the regional level on the African continent, a few treaties or instruments that have a bearing on soil conservation and prevention of land degradation exist. These instruments and initiatives are discussed below. 
5.2.1 African Convention on the Conservation of Nature and Natural Resources, 1968

The African Convention on the Conservation of Nature and Natural Resources is a regional treaty for the African continent that was signed in Algiers in Algeria in 1968, revised in Maputo in 2003, and again revised and adopted on 7 March 2017. Over 30 countries, including Kenya, have ratified the treaty. The objectives of the convention are to enhance environmental protection; foster the conservation and sustainable use of natural resources; and to harmonise and coordinate policies in those fields - all with a view to achieving ecologically rational, economically sound, and socially acceptable development policies and programmes. ${ }^{319}$ Some of the principles to guide state parties to the convention are that it is the right of all people to a satisfactory environment that is favourable to their development, and the individual and collective duty of states to ensure that developmental and environmental needs are met in a sustainable and equitable manner. The convention has defined natural resources that form the subject of protection under the convention as including soil. ${ }^{320}$ In our view, it is impossible to achieve the objective and abide by the principle of the convention, namely, to ensure development and environmental needs are met without taking soil conservation into account. This is because soil is an important facet of social and economic development, because it enhances food security. More fundamentally, Article VI contains provisions relating to land and soil, and expressly provides that state parties will take effective measures to prevent land degradation and to that effect will develop long-term strategies for conservation and management of land resources, including soil. The convention further provides that states are to adopt measures for conservation and improvement of soil, including combating its erosion and misuse, and deterioration of its physical, biological, chemical and economic properties. ${ }^{321}$ In particular, states are obligated to improve soil conservation, introduce sustainable farming practices, and control erosion caused by land misuse and mismanagement when implementing agricultural practices and undertaking agrarian reforms. ${ }^{322}$ To this extent, therefore, it can be argued that this convention both directly and indirectly empowers state parties that have ratified it, including Kenya, to take measures to conserve soil and prevent land degradation.

319 Article II.

320 Article V(1).

321 Article VI(1) and (2).

322 Article VI( $3 b)$. 
5.2.2 Action Plan of the African Union/New Partnership for Africa's

Development Environment Initiative

The Action Plan of the African Union/New Partnership for Africa's Development Environment Initiative was prepared after a consultative and participatory leadership meeting of environment ministers in Africa under the auspices and leadership of the African Ministerial Conference on the Environment (AMCEN) in response to the call of the New Partnership for Africa's Development (NEPAD) for the development and adoption of an environment initiative to deal with Africa's environmental challenges. The action plan was adopted in Maputo on 12 July 2003 by the Summit of the African Heads of State and its implementation began in 2004. AMCEN work programme serves as an integral part of the action plan whose implementation is usually conducted by the United Nations Environment Programme (UNEP) and other collaborative agencies. Programme area 1 under the work programme of AMCEN covers the thematic area of combating desertification, land degradation and drought.

The implementation of the NEPAD initiative in general in Kenya was formalised through an executive order by the President in the year 2002, and a National Steering Committee was put in place to spearhead the participation of Kenya in the process. By the time the Environment Initiative Action Plan was being adopted in the following year, Kenya had already institutionalised the wider NEPAD initiative.

\subsubsection{NEPAD's Initiative for the Resilience and Restoration of African Landscapes}

The Initiative for the Resilience and Restoration of African Landscapes was launched by NEPAD in Paris on 6 December 2015. It seeks to build the resilience of landscapes on the African continent and particularly those in drylands and other vulnerable areas. The initiative is implemented through restoration efforts and specifically through biodiversity conservation, climate-smart agriculture, rangeland management, and forest and ecosystem conservation. The initiative works closely with the African Forest Landscape Restoration Initiative to bring up to 100 million hectares of degraded and deforested land on the continent under restoration by 2030. It is envisaged that the initiative will lead to improved soil fertility and food security, and combat desertification.

With respect to the level of implementation of the initiative in Kenya, we were unable to ascertain whether any programmes under the initiative have been rolled out. However, it is crucial to note that the Ministry of Environment and Natural Resources is currently spearheading the planting of 10 million trees in the Maasai Mau Forest within the larger Mau Forest Complex that serves as a vital water tower. The programme began with the planting of 3 million trees on 1 November 2019. Apart from 
ensuring water provision by protecting the water catchment area, the initiative will ensure the conservation of soil through reforestation and restoration programmes.

\subsubsection{Protocol Concerning Protected Areas and Wild Fauna and Flora in the Eastern African Region, 1985}

The Protocol Concerning Protected Areas and Wild Fauna and Flora in the Eastern African Region was adopted in Nairobi, Kenya, on 21 June 1985 with the objective of protecting threatened and endangered species of flora and fauna and important natural habitats within the East African region. Article 8 of the Protocol provides that parties are to establish protected areas to safeguard important ecosystems, including those that provide habitats for endangered, endemic, migratory and economically important species of flora and fauna. Soil and forests, which ensure soil conservation form important ecosystems or habitats for these species and therefore this Protocol by implication requires the protection of soil, albeit indirectly. The Protocol also prohibits activities that have adverse effects on the habitats of endangered species, including the destruction of critical habitats and, in our view, this subsumes the protection of soil from degradation.

\subsection{National policies}

\subsubsection{National Environment Policy, 2014}

The National Environment Policy ${ }^{323}$ proposes measures to enhance conservation and management of ecosystems and sustainable use of natural resources. The policy states that urban environmental degradation - through a lack of appropriate waste management and sanitation systems - and industry- and transport-related pollution have an adverse impact on soil quality. ${ }^{324}$ The main human activities contributing to environmental degradation in Kenya include unsustainable land use practices, poor soil and water management practices, deforestation, overgrazing and pollution. ${ }^{325}$

The measures proposed in the policy for conservation of soil are: development and implementation of a National Soil Conservation Policy; promotion and support of eco and organic farming so as to maintain soil fertility of wetlands, riverbanks, hilltops and slopes, and to protect them from unsustainable practices and prevent soil erosion and environmental degradation; promotion of good soil management practices to avert

323 Government of Kenya (2013b).

324 Ibid.: vi.

325 Ibid.: 4. 
landslides, mudslides, floods and other disasters that are preventable; and involvement and empowerment of communities in soil conservation. ${ }^{326}$

\subsubsection{National Land Policy, 2009}

The National Land Policy was Kenya's first ever land policy. It provides policy direction for land administration, access to land, land-use planning, restitution of historical injustices, environmental degradation, land-use conflicts, control of unplanned proliferation of informal urban settlements, and a legal and institutional framework for land governance and management and land information management. It also addresses issues of tenure, compulsory acquisition and development control.

The policy states that sustainable land-use practices are key to the provision of food security and attainment of food self-sufficiency. It identifies key problems that need to be resolved at the level of policy and law, which include: land deterioration due to population pressure, massive soil erosion and variability in climatic patterns, among other things; uncontrolled subdivision of land; overstocking in rangelands; and lack of alternative innovative land uses and planning for diversification of the rural economy. ${ }^{327}$ The policy also states that the government must ensure that all land is put into productive use on a sustainable basis by facilitating the implementation of key land policy principles on conservation of land quality, environmental audit and assessment, productivity targets and guidelines, land sizes and land-use planning. ${ }^{328}$

The policy stipulates that to restore the environmental integrity of land and facilitate sustainable management of land-based resources, the government will introduce incentives to encourage use of technology and scientific methods for soil conservation; encourage use of traditional land conservation methods; establish measures to control degradation of land through abuse of inputs and inappropriate land-use practices; and establish institutional mechanisms for conservation of the quality of land for environmental conservation purposes. ${ }^{329}$

The policy identifies the environmental problems Kenya faces as including the degradation of natural resources such as forests, wildlife, water, and marine and coastal resources, as well as soil erosion and the pollution of air, water and land. It calls for measures on conservation and sustainable management of the environment, ecosystem protection, urban environment management, and environmental assessment and audits, to address these problems. ${ }^{330}$

326 Ibid.: 18.

327 Government of Kenya (2009: 28).

328 Ibid.: 28 .

329 Ibid.: 30 .

330 Ibid. 
EIAs and audits are also identified as tools for land management that the government should implement for all proposed projects, programmes and activities on land that have a likelihood to degrade the environment. Monitoring of urban and rural environmental degradation is also required to be done regularly: encouraging public participation in the monitoring and protection of the environment; instituting enforcement mechanisms such as the 'polluter pays principle'; and providing incentives to promote cleaner production and prevent pollution of soil, water and air.

\subsubsection{National Land Use Policy, 2017}

The overall goal of the National Land Use Policy ${ }^{331}$ is to provide the legal, administrative, institutional and technological framework for optimal utilisation and productivity of land-related resources in a sustainable and desirable manner at the national, county and community levels. ${ }^{332}$ The policy is premised on the philosophy of economic productivity, social responsibility, environmental sustainability and cultural conservation. Key principles informing it include efficiency, access to land-use information, equity, elimination of discrimination, and public benefit-sharing. ${ }^{333}$

The policy notes that the interaction between physical processes and human activities produce land cover changes or alterations of the properties of the land surface. These take different forms, such as conversion or modification, which leads to secondary environmental impacts (such as soil erosion, microclimatic changes and changes in water quality, among others) and reflects human goals mirrored on land use and land-use changes. ${ }^{334}$ It points out that in several parts of the country, agricultural potential is limited because of erosion, low fertility, rockiness and acidity of the soils, and the danger of landslides. ${ }^{335}$ Land deterioration has also occurred due to population pressure, massive soil erosion arising from poor land-use practices and variability in climatic patterns. This has led to rapid depletion of land cover and creeping desertification in arid and semi-arid lands, which has in turn affected the capacity for regeneration of the country's water catchment areas. ${ }^{336}$ It notes that the country's coastal region is affected by soil erosion. ${ }^{337}$ Further, cultivation on marginal lands and fragile ecosystems lead to environmental degradation and other challenges such as: loose soils, destruction of ecosystems and microclimatic conditions, soil erosion,

331 Government of Kenya (2017b).

332 Ibid.: v.

333 Ibid.

334 Ibid.: 14.

335 Ibid.: 16.

336 Ibid.: 17.

337 Ibid. 
eutrophication and increased rainwater runoff. ${ }^{338}$ Unsustainable farming methods in these sensitive areas have resulted in severe soil erosion and degradation, which has reduced the overall capacity for sustainable food production in the country, ${ }^{339}$ massive soil erosion arising from bad land-use practices, and variability in climatic patterns. ${ }^{340}$

To promote and ensure productive and sustainable use of land, the policy exhorts the government to develop a framework to facilitate an assessment of land resources, including basic soil surveys, farming systems, soil degradation surveys, and production potentials of the soils in the country. ${ }^{341}$ To address the problem of cultivation on marginal lands and fragile ecosystems, the government is required to encourage the use of modern farming practices that sustain crop yields and soil fertility. ${ }^{342}$ The policy notes that soil mapping is done by different organisations, which affects coordinated action to sustainably manage soils. There is, therefore, a need for unified mechanisms for collection, storage and dissemination of environmental and natural resources information. ${ }^{343}$

\subsubsection{National Climate Change Action Plan, 2013}

The National Climate Change Action Plan aims to further develop Kenya's development goals by providing mechanisms and measures to achieve low-carbon climateresilient development in a manner that prioritises adaptation. Priority adaptation actions identified in the plan which affect soil include increasing forest cover to $10 \%$ of total land area and rehabilitation of degraded lands. ${ }^{344}$

\subsection{National Laws}

\subsubsection{The Constitution of Kenya, 2010}

Kenya's 2010 Constitution fundamentally changed the legal landscape for environmental conservation, management, and dispute resolution mechanisms and processes in Kenya. In its preamble, the Constitution recognises the need to respect and sustain the environment for the benefit of current and future generations.

338 Ibid.: 23.

339 Ibid.: 24.

340 Ibid.: 37.

341 Ibid.: 38 .

342 Ibid.: 44.

343 Ibid.: 53.

344 Government of Kenya (2018b: 37). 
At the heart of the national values and principles of governance, which bind all persons and state organs, spelt out in the Constitution, is the principle of sustainable development. ${ }^{345}$ Sustainable development is development that meets the needs of the present without compromising the ability of future generations to meet their own needs. ${ }^{346}$

The Constitution enhances access to environmental justice. For the first time in the history of Kenya, environmental rights are classified as fundamental human rights in the Constitution. ${ }^{347}$ In this regard, every person in Kenya is entitled to a healthy soil environment and to be informed of the ecological state and condition of the soil. The Constitution also tempers the rigours of the doctrine of locus standi that had hitherto hampered access to environmental justice. ${ }^{348}$ If a person alleges that a right to a clean and healthy environment has been, is being or is likely to be denied, violated, infringed or threatened, the person may apply to a court for redress in addition to any other legal remedies that are available in respect to these issues. ${ }^{349}$

Every citizen has the right of access to information held by the state and information held by another person and required for the exercise or protection of any right or fundamental freedom. ${ }^{350}$ The need for a person to expressly make an application for access to information was affirmed by Mumbi Ngugi J. in Nairobi Law Monthly Company Limited v Kenya Electricity Generating Company \& 2 Others [2013] eKLR, where she held that:

what is required is for the person seeking information to make a request for such information. A violation of the right to information cannot be alleged before a request for information has been made.

However, while there is a condition for parties to expressly apply for such information, the High Court in Nairobi Law Monthly Company Limited v Kenya Electricity Generating Company held that even though the right to information implies entitlements to the citizen to information, it also imposes a duty on the state with regard to provision of information. Thus, the state has a duty not only to publish information proactively in the public interest, which in the judge's view is the import of Article 35(3) of the Constitution of Kenya. This provision imposes an obligation on the state to "publish and publicize any important information affecting the nation", and also to "provide open access to such specific information as people may require from the State". 351

The Constitution establishes the Environment and Land Court (ELC), ${ }^{352}$ a superior court of record, where all environment and land matters are to be adjudicated. The

345 Article 10(2)(d).

346 World Commission on Environment and Development (1987).

347 Article 42.

348 Article 70.

349 Article 70(1).

350 Article 35(1)(9)(a) and (b).

351 Nairobi Law Monthly Company Limited v Kenya Electricity Generating Company \& 2 Others [2013] eKLR.

352 Article 162(2)(b). 
court has powers to hear and determine disputes relating to soil conservation and management.

According to Article 60 of the Constitution, land in Kenya is held, used and managed in a manner that is equitable, efficient, productive and sustainable, and in accordance with the principles of sustainable and productive management of land resources as well as sound conservation and protection of ecologically sensitive areas. These principles are to be implemented through a national land policy developed and reviewed regularly by the national government and through legislation. Land is defined in the Constitution to include the surface of the earth and the subsurface rock and natural resources completely contained on or under the surface. ${ }^{353}$ The state is given powers to regulate use of any land and property. ${ }^{354}$

The National Land Commission is mandated under Article 67 of the Constitution, to conduct research related to land and natural resources and to make recommendations to appropriate authorities. The commission could study specific aspects of soil and carry out ecological surveys to inform decision-making.

To manage and conserve the environment, the state is obliged under Article 69 of the Constitution to: ensure sustainable exploitation, utilisation, management and conservation of the environment and natural resources and ensure the equitable sharing of the accruing benefits; to work to achieve and maintain a tree cover of at least $10 \%$ of the land area of Kenya; to protect and enhance intellectual property in, and indigenous knowledge of, biodiversity and genetic resources, and biological diversity; to establish systems of environmental impact assessment, environmental audit and monitoring of the environment; to eliminate processes and activities that are likely to endanger the environment; and to utilise the environment and natural resources for the benefit of the people of Kenya.

These provisions have implications for soil governance. Further, every person has a duty to cooperate with state organs and other persons to protect and conserve the environment and ensure ecologically sustainable development and use of natural resources. ${ }^{355}$ Consequently, every person has a duty to protect and conserve soil for the benefit of current and future generations. The state's obligations under Article 69 of the Constitution can be invoked for sustainable management of soil. For instance, given the importance of soil in maintenance of biodiversity, the state should, in particular, protect and manage soil biodiversity.

In regard to the distribution of functions between the national and county governments, the national government is responsible for the protection of the environment and natural resources with a view to establishing a durable and sustainable system of development, including, in particular fishing and hunting; protection of animals and 
wildlife; water protection, securing efficient residual water, hydraulic engineering and the safety of dams; and energy policy.

The county governments are charged with the responsibility of implementing specific national government policies on natural resources and environmental conservation, including soil and water conservation, and forestry. ${ }^{356}$ Soil conservation is therefore a shared function of both the national and county governments and they should work cooperatively and collaboratively to ensure sustainability.

The sharing of responsibilities between the two levels of government and the overall transition to the new form of governance have been slow and a source of conflict. County governments have had to force the national government to transfer the functions through courts. ${ }^{357}$ The unwillingness of the national government to cede functions to counties and the uncertainty about the scope of the transferred functions have greatly hampered environmental conservation and efficient delivery of services, including disaster management. ${ }^{358}$

Although soil conservation is primarily a county government function, in practice the national government has retained most soil conservation activities. In areas where the function has been devolved to the counties, county governments have inadequate capacity and funds to adequately conserve the soil. It is worth noting that requisite resources to perform functions should accompany devolution. Further, the national government is obligated by the Constitution to build the capacity of counties to perform devolved functions. The retention of funds at the national level and devolution without capacity-building makes devolution ineffective and affects sectors such as land and soil.

Soil conservation, like other concurrent functions of both levels of government, has not been given much attention by either the national or the county government because of lack of clear role mapping. ${ }^{359}$ The end result has been blame games, with each side evading their role. It is a matter of grave concern that the national government and county governments each have officers and institutions charged with performing the concurrent functions. For instance, the national government and the county governments have employed agricultural extension officers in respect of the same areas. The setting up of parallel systems has adversely affected service delivery in the agricultural sector where the two systems end up not delivering the much-needed services.

Sustainable soil governance hinges on cooperation between the two governments. The Supreme Court has held that this cooperation is inextricably linked to the proper harmonized formulation of policies, management, development and planning of land. ${ }^{360}$

356 Fourth Schedule.

357 Kenya Ferry Services Limited v Mombasa County Government \& 2 others [2016] eKLR.

358 Johnson Kamau Njuguna \& another v Director of Public Prosecutions [2018] eKLR.

359 Mulinge et al. (2016).

360 Council of Governors \& 3 others $v$ Senate \& 53 others [2015] eKLR. 


\subsubsection{Environmental Management and Coordination Act, 1999 (as amended)}

The Environmental Management and Co-ordination Act (EMCA) is the framework environmental law for Kenya. It establishes the legal and institutional framework for managing the environment. According to Section 2 of EMCA, 'environment' includes the physical factors of the surroundings of human beings including land, water, atmosphere, climate, sound, odour, taste, the biological factors of animals and plants and the social factor of aesthetics and includes both the natural and the built environment.

Section 5 of EMCA empowers the cabinet secretary in charge of environment and natural resources to formulate policies and set priorities for the protection of the environment. Section 5 also requires the cabinet secretary to promote cooperation among public departments, local authorities, private sector, non-governmental organisations and such other organisations engaged in environmental protection programmes. Implicitly, the cabinet secretary may formulate policies on soil management and protection.

EMCA establishes NEMA, ${ }^{361}$ which exercises general supervision and coordination over all matters relating to the environment and is the principal instrument of government in the implementation of all policies relating to the environment. ${ }^{362}$ Since soil issues are multidisciplinary in nature, NEMA can therefore coordinate activities being undertaken by public entities on protection and management of soil. Other functions of the authority include coordinating environmental management activities being undertaken by the lead agencies; taking stock of the natural resources; advising on landuse planning; undertaking research, investigating and surveying in the field of environment; and disseminating information on the findings; mobilising and monitoring the use of financial and human resources for environmental management; regulating, monitoring and assessing activities to ensure that the environment is not degraded; enforcing environmental standards; undertaking environmental education, public awareness and public participation programmes; developing, publishing and disseminating manuals, codes and guidelines relating to environmental management; preparing the State of the Environment in Kenya Report; and development and implementation of the national environment action plans. ${ }^{363}$

NEMA's functions under EMCA can be applied to protect and manage soils. NEMA can undertake soil research and prepare information on the ecological condition of the soil environment. Information on the soil environment forms part of the State of the Environment Report, which is prepared by NEMA bi-annually. In addition, NEMA can develop and implement educational and sensitisation programmes on

361 Section 7

362 Section 9(1).

363 Section 9(2). 
sustainable management of soils. NEMA can also prepare and disseminate information to the public on protection of soils.

In the following, some mechanisms and institutions provided for in EMCA that have the potential to protect soil shall be examined in more detail. These are general environmental protection mechanisms not specifically tailored to soil protection.

\subsubsection{National Environment Trust Fund (NETFUND)}

The National Environment Trust Fund is established under Section 24 of EMCA, 1999. A board of trustees administers the fund in accordance with a trust deed, which constitutes the rules and regulations that govern the operations and functions of the fund. The object and purpose of the fund is to facilitate research intended to further the requirements of environmental management, capacity-building, environmental awards, environmental publications, scholarships and grants. ${ }^{364}$ Hence, the fund can support research on soil protection.

\subsubsection{National Environment Restoration Fund}

The 1999 EMCA also established the National Environment Restoration Fund. ${ }^{365}$ Deposit bonds consist of such proportion of fees as may be determined by NEMA from time to time, as well as such sums as may be donated or levied from industries and other project proponents as a contribution towards the restoration fund. The restoration fund is vested in the authority and is administered by the director-general. ${ }^{366}$ The restoration fund acts as supplementary insurance for the mitigation of environmental degradation where the perpetrator is not identifiable or where exceptional circumstances require the authority to intervene towards the control or mitigation of environmental degradation. Consequently, the restoration fund may be used to control to mitigate soil degradation. The cabinet secretary may, by notice in the Gazette, issue orders for the levying of funds from project proponents towards the restoration fund. Administrative procedures for undertaking soil rehabilitation and restoration should however be developed. 


\subsubsection{Deposit bonds}

Under Section 28 of EMCA, the authority is required to create a register of those activities and industrial plants and undertakings which have or are most likely to have significant adverse effects on the environment when operated in a manner that is not in conformity with good environmental practices. The cabinet secretary responsible for finance may, on the recommendations of the cabinet secretary in charge of environment and natural resources, prescribe that persons engaged in activities or operating industrial plants and other undertakings identified in the register pay such deposit bonds as may constitute appropriate security for good environmental practice. The deposit bond determined should be refunded to the operator of the activity, industrial plant or any other undertaking by the authority after such duration not exceeding six months without interest where the operator has observed good environmental practices to the satisfaction of the authority. The authority may, after giving the operator an opportunity to be heard, confiscate a deposit bond where the operator is responsible for environmental practice that is in breach of the provisions of EMCA. The authority may in addition cancel any licence issued to the operator under this act if the authority is satisfied that the operator has become a habitual offender. Where operators are dissatisfied with the confiscation of their deposit bonds, they may refer the matter to a competent court of law. The proceeds of every refundable deposit bond levied are paid into the restoration fund and are treated as part of the restoration fund until refunded to the depositor. Any interest accruing from monies deposited into the restoration fund are for the benefit of the authority.

\subsubsection{County environment committees}

EMCA establishes the county environment committees (CECs) ${ }^{367}$ The committees are constituted by the governor through a Gazette notice and are chaired by members of the executive committee in charge of environmental matters. Other members of the committee include one representative for each of the ministries responsible for the matters specified in the First Schedule of EMCA at the county level; two representatives of farmers or pastoralists within the county to be appointed by the governor; two representatives of the business community operating within the concerned county appointed by the governor; two representatives of the public benefits organisations engaged in environmental management programmes within the county. An officer of NEMA whose area of jurisdiction falls wholly or partially within the county is the secretary to the CEC.

367 Section 30. 
In making the appointments, the governor should ensure that there are equal opportunities for persons with disabilities and other marginalised groups; and that not more than two-thirds of the members are of the same gender. Members of the CECs, except the chairperson and the secretary, are required to hold office for a period of three years and are eligible for re-appointment for one further term. The provision on the term of office for representatives of the ministries at the county level assumes that the length of posting of the representatives runs concurrently with the appointment as member of the CEC. However, this is not the case and there is a possibility that a ministerial representative continues to perform the functions of the Ministry at county level after their term as a member of the county environment committee has expired.

CECs are responsible for proper management of the environment within the county. They are also responsible for development of county strategic environmental action plans every five years. The committees may also perform such additional functions as are prescribed by EMCA or as may, from time to time, be assigned by the governor by notice in the Gazette. Soil protection could be one such additional function.

\subsubsection{National Environment Complaints Committee (NECC)}

The National Environment Complaints Commission is mandated to investigate any allegations or complaints against any person or against the authority in relation to the condition of the environment in Kenya. The NECC was established under Section 31 of the EMCA, 1999. It was formerly known as the Public Complaints Committee (PCC) but its name changed in the EMCA (Amendment) No. 5 of 2015). It is an important institution in the assessment of the condition of the environment in Kenya. It plays an important role in the facilitation of alternative dispute resolution mechanisms relating to environmental matters. The NECC makes recommendations to the Cabinet Secretary and thus contributes significantly to the formulation and development of environmental policy. The commission is also mandated on its own motion, to investigate any suspected case of environmental degradation, and to make a report of its findings together with its recommendations thereon to the council. It can also undertake public interest litigation on behalf of the citizens in environmental matters. Hence the commission can take legal action against any person who causes soil degradation.

\subsubsection{National Environment Action Plans}

The authority is required to formulate the National Environmental Action Plan every six years through a participatory process. The authority is required to submit the plan to the cabinet secretary for approval. Upon approval of the plan, the cabinet secretary 
has an obligation to submit the plan to the National Land Commission and the Ministry responsible for land. The cabinet secretary is required to publish the plan in the $\mathrm{Ga}$ zette. NEMA should review the National Environment Action Plan every three years. The plan is binding on all persons, government departments, agencies, state corporations and other organs of government upon adoption by the National Assembly.

The purpose of environmental action plans is to coordinate and harmonise environmental policies, plans, programmes and decisions of the national and county governments, as the case may be, in order to minimise the duplication of procedures and functions; promote consistency in the exercise of functions that may affect the environment; secure the protection of the environment across the country; and prevent unreasonable actions by any person, state organ or public entity in respect of the environment that are prejudicial to the economic or health interests of other counties or the country. ${ }^{368}$ Soil plans could be integrated in the National Environmental Action Plans.

\subsubsection{County Environment Action Plans}

Every county environment committee is required to develop a county environmental action plan in respect of the county every five years through a participatory process. This action plan is considered and adopted by the County Assembly. In preparing a county environment plan, the County Environment Committee should take into consideration every other county environment action plan already adopted, with a view to achieving consistency among such plans. Upon adoption by the County Assembly, the County Environment Action Plan should be submitted to the cabinet secretary for incorporation into the national environment action plan. Every county environment action plan should contain provisions dealing with matters contained in the National Environment Action Plan in relation to their respective county. ${ }^{369}$

The authority is obligated to consider every county environment action plan and either recommend incorporation of such plan into the National Environment Action Plan or specify changes to be incorporated into a county environmental plan. The cabinet secretary is empowered, on the recommendation of NEMA, to issue guidelines and prescribe measures for the preparation of environmental action plans. The guidelines and measures may include guidelines on soil planning, ecological limits of use of soil, soil zoning and soil classification. The contents of the county environmental plans are similar to those of the National Environment Action Plan. 


\subsubsection{Monitoring compliance with Environmental Plans}

The obligation for monitoring compliance with national and county environmental action plans rests with NEMA. ${ }^{370}$ NEMA may take any steps or make any inquiries that it may consider necessary in order to determine if the plans are being complied with. If as a result of any action taken or inquiry, NEMA is of the opinion that a plan is not substantially being complied with, NEMA will serve a written notice to the organ concerned, calling on it to take such specified steps NEMA may consider necessary to remedy noncompliance. Within 30 days of the receipt of the notice, the organ will respond to the notice in writing, setting out any objections to the notice; the action that will be taken to ensure compliance with the plan; or other information that the organ considers relevant to the notice.

After considering the representations from the organ and any other relevant information, NEMA will within 30 days of receiving the response issue a final notice to either confirm amend or cancel the notice or to specify any action and a time period within which such action must be taken to remedy non-compliance. The authority should keep a record of all environmental action plans and ensure that such plans are available for inspection by the public.

\subsubsection{Protection and conservation of the environment}

Part V of EMCA deals with the conservation and management of various aspects of the environment. These include the rivers, lakes, wetlands, genetic resources, hill tops, hill sides, mountain areas and forests. Section 44 requires the authority, in consultation with the relevant lead agencies, to develop, issue and implement regulations, procedures, guidelines and measures for the sustainable use of hill sides, hill tops, mountain areas and forests, and such regulations, guidelines, procedures and measures will control the harvesting of forests and any natural resources located in or on a hill side, hill top or mountain area so as to protect water catchment areas, prevent soil erosion and regulate human settlement. Under Section 45(1), every county environment committee is required to identify the hilly and mountainous areas under their jurisdiction which are at risk of environmental degradation. A hilly or mountainous area is at risk of environmental degradation if it is prone to soil erosion; landslides have occurred in such areas; vegetation cover has been removed or is likely to be removed from the area at a rate faster than it is being replaced; or any other land-use activity in such an area is likely to lead to environment degradation.

Every county environment committee must specify which of the areas identified are to be targeted for afforestation or reforestation. Every committee must take measures,

370 Section 41(B). 
through encouraging voluntary self-help activities in its local community, to plant trees or other vegetation which are within the limits of its jurisdiction. Where the areas specified are subject to leasehold or any other interest in land, including customary tenure, the holder of that interest must implement measures required to be implemented by the county environment committee, including measures to plant trees and other vegetation in those areas. ${ }^{371}$

Section 47 of EMCA obligates the authority, in consultation with the relevant lead agencies, to issue guidelines and prescribe measures for the sustainable use of hill tops, hill slides and mountainous areas. The guidelines issued and measures prescribed by the authority must be by way of Gazette notice and must include those relating to appropriate farming methods; carrying capacity of the hill tops, hill slides and mountainous areas in relation to animal husbandry; measures to curb soil erosion; disaster preparedness in areas prone to landslides; the protection of the hill tops, hill slides and mountainous areas from human settlements; the protection of water catchment areas; and any other measures the authority considers necessary. The county environment committee is responsible for ensuring that the guidelines issued, and measures prescribed in respect of their counties are implemented. Any person who contravenes any measure prescribed by the authority or who fails to comply with a lawful direction issued by a county environment committee is guilty of an offence.

\subsubsection{Integrated environmental impact assessment}

According to Section 57A of EMCA, all policies, plans and programmes for implementation must be subjected to strategic environmental assessment. Strategic environmental assessment is a formal and systematic process to analyse and address the environmental effects of policies, plans, programmes and other strategic initiatives. ${ }^{372}$ The plans, programmes and policies that are subject to strategic environmental assessment are those that are prepared or adopted by an authority or parliament at national, county and regional levels. The authority may also determine the policies, plans and programmes which should be subjected to strategic environmental assessment because they are likely to have significant effects on the environment. ${ }^{373}$ The costs of undertaking the strategic environmental assessments are to be borne by the entities preparing the plans, programmes and policies. ${ }^{374}$ The assessments are submitted to the authority for approval. ${ }^{375}$ The authority, in consultation with lead agencies and relevant

371 Section 46.

372 Section 2.

373 Section $57(\mathrm{~A})(2)$.

374 Section $57(\mathrm{~A})(3)$.

375 Section $57(\mathrm{~A})(3)$. 
stakeholders, is required to prescribe rules and guidelines in respect of strategic environmental assessments. ${ }^{376}$

Notwithstanding any approval, permit or licence granted under this Act or any other law in force in Kenya, any proponent of a project must, before applying for any financing, commencing, proceeding with, carrying out, executing, conducting or causing to be financed, commenced, proceeded with, carried out, executed or conducted by another person any undertaking specified in the Second Schedule of the Act, submit a project report to the authority, in the prescribed form, giving the prescribed information and accompanied by the prescribed fee. ${ }^{377}$ The proponent of any project specified in the Second Schedule ${ }^{378}$ must undertake a full environmental impact assessment study and submit an environmental impact assessment study report to the authority prior to being issued with any licence by the authority provided that the authority may direct that the proponent forego the submission of the environmental impact assessment study report in certain cases. ${ }^{379}$ In undertaking environmental impact assessments, proponents of projects have been undertaking soil environmental impact assessments.

To regulate the practice of integrated environmental assessments, the cabinet secretary is mandated, in consultation with NEMA, to make regulations and formulate guidelines for the practice of integrated environmental impact assessments and environmental audits. ${ }^{380}$ The cabinet secretary is also mandated to make regulations for the accreditation of experts on environmental impact assessments. ${ }^{381}$ A person who knowingly submits a report which contains information that is false or misleading commits an offence and is liable, on conviction, to a term of imprisonment of not more than three years, or to a fine of not more than five million shillings, or to both the fine and imprisonment, and in addition his licence will be revoked. ${ }^{382}$

NEMA may cancel or revoke a licence; suspend such licence, for such time, not more than 24 months, where the licensee contravenes the provisions of the licence. Where the authority cancels, revokes or suspends a licence in accordance with this section, the reasons for such action must be given to the licensee in writing.

To enhance public access to information contained in the environmental impact assessment reports, the authority is required to cause to be published a notice of a proposed project not only in the Gazette and at least two newspapers circulating in the

376 Section 57(A)(4).

377 Section 58(1).

378 The activities listed in the Second Schedule which impact on soils include changes in land use, urban development, transportation and related infrastructure projects, mining activities and hydrocarbon projects.

379 Section 58(2).

380 Section 58(6)(A).

381 Section $58(6)(\mathrm{B})$.

382 Section 58(10). 
area or proposed area of the project, but also over the radio. ${ }^{383}$ NEMA is furthermore obliged to ensure that its website contains a summary of the environmental impact assessment reports. ${ }^{384}$ This presents an opportunity to members of the public to access information on soil and involve themselves in decision-making.

\subsubsection{Environmental monitoring}

The authority, in consultation with the relevant lead agencies, is mandated to monitor all environmental phenomena with a view to making an assessment of any possible changes in the environment and their possible impacts; or the operation of any industry, project or activity with a view of determining its immediate and long-term effects on the environment. ${ }^{385}$ An environmental inspector appointed under EMCA may enter any land or premises for the purposes of determining how far the activities carried out on that land or premises conform to the statements made in the Environmental Impact Assessment Study Report issued in respect of that land or those premises. ${ }^{386}$ The owner of the premises or the operator of a project for which an environmental impact assessment study report has been made must keep accurate records and make annual reports to the authority describing how far the project conforms in operation with the statements made in the Environmental Impact Assessment Study Report. ${ }^{387}$ The owner of a premises or the operator of a project must take all reasonable measures to mitigate any undesirable effects not contemplated in the Environmental Impact Assessment Study Report and must prepare and submit an environmental audit report on those measures to the authority annually or as the authority may, in writing, require. ${ }^{388}$

\subsubsection{Environmental quality standards}

The cabinet secretary in charge of environment and natural resources on recommendation of the authority is empowered to prescribe minimum water quality standards; ${ }^{389}$ minimum air quality standards $;{ }^{390}$ standards for waste; their classification and analysis ${ }^{391}$ standard criteria for the classification of hazardous wastes $;{ }^{392}$ standards for the

383 Section 59(1).

384 Section 59(3).

385 Section 69(1).

386 Section 68(2).

387 Section 68(3).

388 Section 68(4).

389 Section 71.

390 Section 78.

391 Section 85.

392 Section 91. 
concentration of pesticide residues in raw agricultural commodities $;{ }^{393}$ minimum standards for emissions of noise and vibration pollution; ${ }^{394}$ and standards for setting acceptable levels of ionizing and other radiation in the environment. ${ }^{395}$ Regarding standards for waste, the cabinet secretary must, on the recommendation of the authority identify materials and processes that are dangerous to human health and the environment; issue guidelines and prescribe measures for the management of the materials and processes identified to be injurious to the environment; prescribe standards for waste, their classification and analysis, and formulate and advise on standards of disposal methods and means for such wastes; or issue regulations for the handling, storage, transportation, segregation and destruction of any waste. It is an offence for any person to discharge or dispose of any wastes, whether generated within or outside Kenya, in such manner as to cause pollution to the environment or ill health to any person. ${ }^{396}$ It is an offence for any person to discharge a hazardous substance, chemical, oil or mixture containing oil into any waters or other areas of the environment. ${ }^{397} \mathrm{~A}$ person convicted of the offence will, in addition to any other sentence imposed by the court, pay the cost of the removal of the hazardous substance, chemical, oil or mixture containing oil including any costs which may be incurred by any government agency or organ in the restoration of the environment damaged or destroyed as a result of the discharge; and the costs of third parties in the form of reparation, restoration, restitution or compensation, as may be determined by a competent court on application by such third parties. ${ }^{398}$

With regard to pesticides and toxic substances, the cabinet secretary must, on the recommendation of the authority, establish standards to regulate the importation, exportation, manufacture, storage, distribution, sale, use, packaging, transportation, disposal and advertisement of pesticides and toxic substances in consultation with the relevant organisations, determine measures for monitoring the effects of pesticides and toxic substances on the environment; determine measures for the establishment and maintenance of laboratories to operate as standards laboratories for pesticides and toxic substances; and determine measures for the establishment of enforcement procedures and regulations for the storage, packaging and transportation of pesticides and toxic substances.

393 Section 94.

394 Section 101.

395 Section 104.

396 Section $87(1)$.

397 Section 93(2).

398 Section 93(3). 


\subsubsection{Environmental restoration orders}

The authority may issue and serve on any person an environmental restoration order in respect of any matter relating to the management of the environment. ${ }^{399}$ An environmental restoration order requires the person on whom it is served to restore the environment to as near as it may be to the state in which it was before the taking of the action which is the subject of the order; prevents the person on whom it is served from taking any action which would or is reasonably likely to cause harm to the environment; awards compensation to be paid by the person on whom it is served to other persons whose environment or livelihood has been harmed by the action which is the subject of the order; and levies a charge on the person on whom it is served which in the opinion of the authority represents a reasonable estimate of the costs of any action taken by an authorised person or organisation to restore the environment to the state in which it was before the taking of the action which is the subject of the order.

An environmental restoration order may require a person on whom it is served to take such action as will prevent the commencement or continuation or cause of pollution; restore land, including the replacement of soil, the replanting of trees and other flora; and the restoration, as far as may be, of outstanding geological, archaeological or historical features of the land or the area contiguous to the land or sea, as may be specified in the particular order; take such action to prevent the commencement or continuation or cause of environmental hazard; cease to take any action which is causing or may contribute to causing pollution or an environmental hazard; remove or alleviate any injury to land or the environment or to the amenities of the area; prevent damage to the land or the environment, aquifers beneath the land and flora and fauna in, on or under or about the land or sea specified in the order or land or the environment contiguous to the land or sea specified in the order; remove any waste or refuse deposited on the land or sea specified in the order and dispose of the same in accordance with the provisions of the order; pay any compensation specified in the order.

\subsubsection{Environmental easements and environmental conservation orders}

A court may grant an environmental easement or an environmental conservation order. ${ }^{400}$ An environmental conservation order may be imposed on burdened land so as to preserve flora and fauna; preserve the quality and flow of water in a dam, lake, river or aquifer; preserve any outstanding geological, physiographical, ecological, archaeological or historical features of the burdened land; preserve scenic view; preserve open space; permit persons to walk in a defined path across the burdened land; preserve the 
natural contours and features of the burdened land; prevent or restrict the scope of any activity on the burdened land which has as its object the mining and working of mineral aggregates; prevent or restrict the scope of an agricultural activity on the burdened land; create and maintain works on the burdened land so as to limit or prevent harm to the environment; or create or maintain migration corridors for wildlife.

\subsubsection{Integrated National Land Use Guidelines}

In the exercise of its powers under Section 9(2) of EMCA, NEMA has developed the Integrated National Land Use Guidelines. ${ }^{401}$ The guidelines are for rivers and lakes and propose a buffer zone of $30 \mathrm{~m}$ for lakes for purposes of minimising soil erosion. ${ }^{402}$ Guidelines for coastal zone areas include protecting near-shore coral reefs from damaging activities such as soil erosion. With regard to agricultural land, the guidelines propose the development and mapping of soil capability profiles for the country in order to carry out different sustainable agricultural activities. ${ }^{403}$ In addition, the guidelines provide that crop production should be done depending on adaptation to designated agro-ecological zones, soil characteristics, recommended agricultural practices and appropriate technologies. ${ }^{404}$ With cultivation on slopes from $0 \%-12 \%$, contour farming and the use of soil conservation measures are recommended; at $12 \%-55 \%$ soil conservation measures are compulsory; and above $55 \%$ perennial/permanent crops (such as Napier grass, tea, bananas and trees) should be planted. ${ }^{405}$ To protect soil against erosion, the guidelines recommend ploughing and planting along the contours, practising crop rotation, applying manure to crops, leaving crop residue on the ground and practising terracing. ${ }^{406}$

The guidelines make specific mention of red soil harvesting. The guidelines encourage the rehabilitation of degraded areas as recommended in environmental impact assessments, environmental audits and environmental management or as per restoration provisions of EMCA. ${ }^{407}$ The guidelines prohibit loose hanging material near or on the face of excavations and quarries. Red soil harvesting should not be carried out in road reserves, near dwellings, and in other environmentally sensitive areas. ${ }^{408}$ The guidelines prohibit vertical faces exceeding $2.5 \mathrm{~m}$ when quarrying on red soil. ${ }^{409}$

401 National Environment Management Authority (2011).

402 Ibid.: 6.

403 Ibid.: 20 .

404 Ibid.

405 Ibid.

406 Ibid.: 21.

407 Ibid.: 28.

408 Ibid.

409 Ibid. 
On flood-prone areas, the guidelines recommend afforestation, tree planting, and water and soil conservation in catchment areas and along watercourses. ${ }^{410}$ On landside-prone areas, the guidelines recommend intensification of soil and water conservation measures in already settled landslide-prone areas. ${ }^{411}$ Siting of infrastructure in landslide-prone areas should be determined by slope, soil characteristics and vegetation cover. ${ }^{412}$

\subsubsection{Assessment of the effectiveness of the Environmental Manangement and Co-ordination Act}

NEMA is tasked to study and examine land-use patterns to determine their impact on the quality and quantity of the natural resources, including soil, and to make recommendations on land planning in Kenya. ${ }^{413}$ The proper performance of this function requires coordination with other government land-use players, such as the Ministry of Lands and Physical Planning, the National Land Commission and county governments. According to the National Land Use Policy, lack of institutional coordination and harmony in the various statutes establishing various government institutions poses a challenge to the overall management of land use in the country. ${ }^{414}$ Accordingly, the government through the National Land Use Policy passed in 2017 aims at providing institutional coordination in land-use planning across all relevant sectors where lack of coordination has led to infringement of agricultural areas, urban sprawl and environmental degradation. ${ }^{415}$

Another factor that has an impact on the effectiveness of EMCA is inadequate resource mapping in Kenya, which limits the effectiveness of environmental conservation measures. Soil conservation requires physical information of vulnerable land and the identifying of available land, and the protection of watersheds, vegetation, topography and drainage courses. Notably, the focus has been on land (mostly water, forests and land accessibility), but not on soils. ${ }^{416}$

As mentioned, the effectiveness of EIA as a tool for balancing development and environmental conservation to mitigate environmental degradation can be enhanced. ${ }^{417}$ EIA can, for instance, be used to address soil pollution from industrial and urban activity. In reality, however, either no EIA is undertaken in many instances where capital

410 Ibid.

411 Ibid.: 29.

412 Ibid.

413 Environment Management and Coordination Act, 1999, Section 9.

414 Government of Kenya, National Land Use Policy, Sessional Paper, No. 1 of 2017, 20.

415 Government of Kenya, National Land Use Policy, Sessional Paper, No. 1 of 2017.

416 Government of Kenya, Royal Netherlands Government \& UNEP "National Land Degradation Assessment and Mapping in Kenya" 1997.

417 Environment Management and Coordination Act, 1999, Section 57. 
intensive projects are carried out or, if undertaken, EIA does not meet the legal threshold. This was the case in Cortec Mining Kenya Limited $v$ Cabinet Secretary Ministry of Mining \& 9 Others [2015] eKLR where mining licences were cancelled on account of failure to conduct EIA. ${ }^{418}$ In instances where the EIA does not meet the legal threshold or is not undertaken at all, the projects have an unmitigated negative impact on the environment. Soil and water resources have been on the receiving end in this regard.

Cognizant of the fact that poor water quality could be the source of the soil degradation, EMCA requires that the cabinet secretary in charge of the environment, in consultation with NEMA, establishes the water quality for agricultural purposes. ${ }^{419}$ Such water quality precludes the use of contaminated water in irrigation. In this regard, the Environmental Management and Coordination Quality Regulations, 2006, were promulgated. Regulation 19 prohibits the use of wastewater for irrigation purposes, unless such water complies with standards set out in the Eighth Schedule of these regulations. A study carried out on the quality of water used in Kenya's largest irrigation scheme, Mwea Irrigation Scheme, revealed that wastewater with high toxic chemicals was widely used in the irrigation scheme, lowering the quality of soils and leading to low productivity. ${ }^{420}$

The law also prohibits disposal of hazardous waste into the environment without a valid permit. The law defines the term hazardous waste as any chemical, waste, gas, medicine, drug, plant, animal or microorganism which is likely to be injurious to human health or the environment. ${ }^{421}$ Ideally, the issuance of a licence ensures that the waste is properly disposed of to minimise environmental impact. Despite the heavy penalty imposed for disposing hazardous waste into the environment without a permit, this provision is barely observed. ${ }^{422}$ Unfortunately, even government entities do not manage the dumpsites and wastes properly, which leads to further environmental degradation. In many instances, citizens have had to force the government to manage waste properly through court actions. ${ }^{423}$

On regulation of standards of pesticides and toxic substances, the law mandates the cabinet secretary, on the recommendation of NEMA, to determine standards to regulate the importation, exportation, manufacture, storage, distribution, sale, use, packaging, transportation, disposal and advertisement of pesticides and toxic substances. ${ }^{424}$ Although Kenya has launched various measures to combat illicit trading of chemicals

418 See also Save Lamu \& 5 others v National Environmental Management Authority (NEMA) \& another [2019] eKLR, where National Environment Tribunal nullified an EIA licence on the grounds that due process of undertaking the EIA was not followed.

419 Environment Management and Coordination Act, 1999, Section 71.

420 Nyabonyi (2016).

421 Environment Management and Coordination Act, 1999, Section 91.

422 Wasilwa \& Nanjala (2019).

423 African Centre for Rights and Governance (ACRAG) \& 3 others v Municipal Council of Naivasha [2017] eKLR.

424 Environment Management and Coordination Act, 1999, Section 94. 
and fertilizers, it is still widespread and the agricultural sector is negatively affected by substandard products, as will be discussed below.

\subsubsection{Forest Conservation and Management Act, 2016}

The Forest Conservation and Management $\mathrm{Act}^{425}$ provides for the development and sustainable management, including conservation and rational utilisation, of all forest resources for the socioeconomic development of the country and related purposes. According to the Act, 'forest produce' includes, among other things, limestone, murram and soil. ${ }^{426}$

Section 7 of the Act establishes the Kenya Forest Service. The functions of the service are to conserve, protect and manage all public forests in accordance with the provisions of the Act; prepare and implement management plans for all public forests; and, where requested, assist in preparation of management plans for community forests or private forests in consultation with the relevant owners; receive and consider applications for licences or permits in relation to forest resources or management of forests or any other relevant matter in accordance with this Act; establish and implement benefit-sharing arrangements in accordance with the provisions of the Act; assist county governments to build capacity in forestry and forest management in the counties; develop, in consultation with relevant stakeholders, programmes for tourism and recreational and ceremonial use of public forests; promote forestry education and training; register and maintain a register of all forest management plans prepared for public forests; collaborate with relevant persons in identifying research needs and applying research findings in relation to forests and forestry; and manage water catchment areas in relation to soil and water conservation, carbon sequestration and other environmental services in collaboration with relevant stakeholders.

All indigenous forests and woodlands will be managed on a sustainable basis for purposes of conservation of water, soil and biodiversity, as well as riparian and shoreline protection. ${ }^{427}$

\subsection{Quarrying}

The Kenya Forest Service should only grant its consent for quarrying operations in a forest area where an independent environmental impact assessment or audit has been

425 No. 34 of 2016.

426 Section 2.

427 Section 42(1)(a) and (b). 
carried out. ${ }^{428}$ The cabinet secretary will, on the recommendation of the service, and in consultation with the cabinet secretary responsible for the environment and the relevant government agencies, publish rules to regulate and govern quarrying operations in forest areas. The conditions on which a licence for quarrying any allied activity carried out in the forest, will, where the activity concerned is likely to result in the depletion of forest cover in any forest, include a condition requiring the licensee to undertake compulsory restoration and re-vegetation immediately upon the completion of the activity. ${ }^{429}$ Re-vegetation will be undertaken in consultation with the service, which will determine the seeds and seedlings proposed to be used in the re-vegetation. ${ }^{430}$

\subsection{Incentives for increasing forest and tree cover}

The cabinet secretary for the National Treasury may propose tax and other fiscal incentives to increase investments in forestland use and forest resource utilisation in order to promote forest conservation and management, and to prevent or arrest forest degradation. ${ }^{431}$ The tax and fiscal incentives may include the following: a customs and excise waiver in respect of imported capital goods or tax rebates to forest industries and other establishments investing in plants, equipment and machinery for improved resource utilisation and for using other energy resources as substitutes for hydrocarbons; exemption from payment of all or part of the land rates and other such charges as may be levied in respect of the land on which a private forest is established; and income and other tax deductions to landowners in exchange for the establishment of a forest conservation easement. ${ }^{432}$ The cabinet secretary will plan and execute programmes necessary for observing the national tree-planting week and the International Day of Forests. ${ }^{433}$

Section 64 of the Act prohibits certain activities in the forest, except under a licence or permit or a management agreement issued or entered into under the Act. No person is permitted, in a public or provisional forest, to fell, cut, take, burn, injure or remove any forest produce; smoke, where smoking is prohibited by notice, or kindle, carry or throw down any fire, match or other lighted material; de-pasture or allow any livestock to run there; clear, cultivate or break up land for cultivation or for any other purpose; construct any road or path; or set fire, or assist any person to set fire, to any grass or undergrowth or any forest produce. Any person who undertakes any of the prohibited

428 Section $46(1)(\mathrm{c})$.

429 Section 46(4).

430 Section 46(5).

431 Section 54(1).

432 Section 54(2).

433 Section 55. 
activities commits an offence and is liable, on conviction, to a fine not exceeding 100,000 shillings or to imprisonment for a term not exceeding six months, or to both the fine and imprisonment.

\subsubsection{Water Act, 2016}

The Water Act ${ }^{434}$ provides for the regulation, management and development of water resources, water and sewerage services, and other related purposes. According to the Act, 'water resource management' means the conservation, including soil and water conservation, protection, development and utilisation of water resources. ${ }^{435}$ A person may not provide water services except under a licence issued by the Regulatory Board, upon submission of an application and such supporting documents as the board may require. ${ }^{436} \mathrm{~A}$ licensee may enter into an agreement with any person with respect to the execution and maintenance, by any party to the agreement, of such works as the licensee considers necessary or as the conditions of the licence may require for the purpose of protecting the catchment areas, draining of land, carrying out soil conservation measures, controlling vegetation or effectively collecting, conveying or preserving the purity and quantity of water which the licensee is for the time being authorised to take. ${ }^{437}$

\subsubsection{Climate Change Act, 2016}

Kenya has a National Climate Change Action Plan, ${ }^{438}$ a National Climate Change Framework Policy ${ }^{439}$ and a Climate Change Act. ${ }^{440}$ These legal instruments seek to reduce causes of climate change, to create climate change resilience, to enable climate financing, to manage knowledge, to develop capacity, and to cater for technology requirements, monitoring and reporting.

The Climate Change Act applies to the development, management, implementation and regulation of mechanisms to enhance climate change resilience and low carbon development for the sustainable development of Kenya. It applies in all sectors of the economy and is implemented by the national and county governments to mainstream climate change responses in development planning, decision-making and

434 No. 43 of 2016.

435 Section 2.

436 Section 85(1).

437 Section 104(1).

4382013.

4392016.

440 No. 11 of 2016. 
implementation; to build resilience and enhance adaptive capacity to the impacts of climate change; to formulate programmes and plans to enhance the resilience and adaptive capacity of human and ecological systems to the impacts of climate change; to mainstream and reinforce climate change disaster risk reduction into strategies and actions of public and private entities; and to mainstream intergenerational and gender equity in all aspects of climate change responses, among others. ${ }^{441}$

The Act establishes the Climate Change Council, which provides an overarching national climate change coordination mechanism. The council is required to ensure the mainstreaming of the climate change function by the national and county governments and to approve and oversee implementation of the National Climate Change Action Plan. ${ }^{442}$ The Act also establishes the Climate Change Directorate, which provides analytical support on climate change to the various sector ministries, agencies and county governments. ${ }^{443}$

Kenya has positioned itself as a global leader in sustainable development of energy production by greening the energy sector. In this regard, Kenya currently hosts the largest wind power plant in Africa ${ }^{444}$ The country's bourse regulator, the Capital Markets Authority, has approved the trading of Kenya's first green bond to build environmentally friendly student accommodation. ${ }^{445}$ Lending institutions, cognizant of the threat posed by climate change, have been offering credit guidance to land and soil conservation. For instance, F3 Life, a private lender, offers farmers affordable green loans whose interest rates are determined by the quality of soil conservation practised by the farmer. This is a transformative integrated agenda that combines credit and soil conservation. ${ }^{446}$

\subsubsection{Land laws}

Land tenure types and policies usually influence land-use practices and hence affect the quality of soils. All land in Kenya belongs to the people of Kenya collectively as a nation, as communities and as individuals. ${ }^{447}$ Land is classified as public, community or private. ${ }^{448}$

441 Section 2.

442 Section 6.

443 Section 9.

444 Salaudeen (2019).

445 See https://www.cma.or.ke/index.php?option=com_content\&view=article\&id=591:press-release-cma-approves-kenya-s-first-green-bond\&catid $=12$ :press-center $\&$ Itemid $=207$ accessed 6 November 2019.

446 See http://farmbizafrica.com/profit-boosters/1434-farm-loan-pegs-interest-on-soil-conservation, accessed 3 November 2019.

447 Article 61(1) of the Constitution.

448 Article 61(2) of the Constitution. 
Public land comprises alienated government land used or occupied by any state organ, except land that is occupied by the state organ as lessee under a private lease; land transferred to the state by way of sale, reversion or surrender; and land in respect of which no individual or community ownership can be established by any legal process; land in respect of which no heir can be identified by any legal process; all minerals and mineral oils; government forests and other community forests; game reserves, water catchment areas, national parks, government animal sanctuaries, and specially protected areas; all roads and thoroughfares; all rivers, lakes and other water bodies; the territorial sea, the exclusive economic zone and the sea bed; the continental shelf; all land between the high and low water marks; any land not classified as private or community land under the Constitution; and any other land declared to be public land by an act of Parliament. ${ }^{449}$

Public land vests in and is held by a county government in trust for the people resident in the county, and is administered on their behalf by the National Land Commission, if it is classified as alienated government land; land transferred to the state by way of sale, reversion or surrender; land in respect of which no individual or community ownership can be established by any legal process; and land in respect of which no heir can be identified by any legal process and land lawfully held, used or occupied by any state organ, except any such land that is occupied by the state organ as lessee under a private lease other than land held, used or occupied by a national state organ. ${ }^{450}$ All other public land vests in and is held by the national government in trust for the people of Kenya and is administered on their behalf by the National Land Commission. ${ }^{451}$ Public land, especially forestland is often invaded by individuals or groups because of insecurity of tenure. The invaders usually over-exploit the resources, leading to soil degradation.

Community land vests in and is held by communities identified on the basis of ethnicity, culture or similar communities of interest. ${ }^{452}$ Community land consists of land lawfully registered in the name of group representatives under the provisions of any law; land lawfully transferred to a specific community by any process of law; any other land declared to be community land by an act of Parliament; land that is lawfully held, managed or used by specific communities as community forests, grazing areas or shrines; ancestral lands and lands traditionally occupied by hunter-gatherer communities; or land lawfully held as trust land by the county governments, but not including any public land held in trust by the county government. ${ }^{453}$ Any unregistered community land is held in trust by county governments on behalf of the communities for which

449 Article 62(1) of the Constitution.

450 Article 62(2) of the Constitution.

451 Article 62(3) of the Constitution.

452 Article 63(1) of the Constitution.

453 Article 63(2) of the Constitution. 
it is held. ${ }^{454}$ Private land consists of registered land held by any person under any freehold tenure; land held by any person under leasehold tenure; and any other land declared private land under an act of Parliament. ${ }^{455}$

\subsubsection{Land Act, 2012}

The Land Act ${ }^{456}$ gives effect to Article 68 of the Constitution. It also consolidates and rationalises land laws and provides for the sustainable administration and management of land and land-based resources. Article 68 empowers Parliament to revise, consolidate and rationalise existing land laws; revise sectoral land-use laws in accordance with the principles set out in Article 60(1); enact legislation to, among others, prescribe minimum and maximum land-holding acreages in respect of private land; regulate the manner in which any land may be converted from one category to another; and protect, conserve and provide access to all public land.

With regard to management and administration of land, the cabinet secretary is empowered to develop policies on land, upon the recommendation of the National Land Commission; facilitate the implementation of land policy and reforms; coordinate the management of the National Spatial Data Infrastructure; monitor and evaluate land sector performance; provide policy direction regarding all classes of land in consultation with the commission, where appropriate; and coordinate the development and implementation of a National Land Information System in collaboration with the commission. ${ }^{457}$

In managing public land on behalf of the national and county governments, the commission evaluates all parcels of public land based on land capability classification, land resources mapping considerations, overall potential for use, and resource evaluation data for land-use planning. The commission may require the land to be used for specified purposes subject to such conditions, covenants, encumbrances or reservations specified in the relevant order or other instrument. ${ }^{458}$ The commission prescribes guidelines for the management of public land by all public agencies, statutory bodies and state corporations in actual occupation or use of public land. The guidelines must indicate management priorities and operational principles for the management of public land resources for identified uses. ${ }^{459}$

454 Article 63(3) of the Constitution.

455 Article 64 of the Constitution.

456 No. 6 of 2012.

457 Section 6.

458 Section 8.

459 Section 10. 


\subsection{Development plans}

The commission will, upon request by the national or county government, by order in the Gazette, reserve public land located in the public interest. ${ }^{460}$ A management body will, on its own motion or at the request of the commission, submit to the commission for approval a plan for the development, management and use of the reserved public land vested in the management body ${ }^{461}$ Before submitting a plan to the commission, a management body will consider any conservation, environmental or heritage issues relevant to the development, management or use of the public land in its managed reserve for the purpose of that managed reserve; incorporate in the plan a statement that it has considered those issues in drawing up the plan; submit an environmental impact assessment plan pursuant to existing law on environment; and comply with the values and principles of the constitution. ${ }^{462}$ If a management body submits a plan to the commission and the commission approves that plan and notifies the management body of that fact, the management body may develop, manage and use the public land concerned in accordance with the plan as approved or subsequently varied, as the case may be. ${ }^{463}$ If a management body does not comply with guidelines or directions issued by the commission in writing, or does not submit a development plan in compliance with a request made, the commission, by order in the Gazette, may revoke that management order. ${ }^{464}$ If the commission considers that it is in the public interest to revoke a management order, the commission may, by order in the Gazette, revoke the management order. ${ }^{465}$ The preparation and implementation of development plans will be in accordance with the physical planning regulations and any other relevant law. ${ }^{466}$

\subsection{Conservation of land-based natural resources}

The commission makes rules and regulations for the sustainable conservation of landbased natural resources. The rules and regulations may contain measures to protect critical ecosystems and habitats; incentives for communities and individuals to invest in income-generating natural resource conservation programmes; measures to facilitate the access, use and co-management of forests, water and other resources by communities who have customary rights to these resources; procedures for the registration of natural resources in an appropriate register; procedures on the involvement of

460 Section 15.

461 Section 17(1).

462 Section $17(2)$.

463 Section 17(3).

464 Section 18(1).

465 Section 18(2).

466 Section 18(3). 
stakeholders in the management and utilisation of land-based natural resources; and measures to ensure benefit-sharing to the affected communities. ${ }^{467}$

Section 135 of the Land Act establishes the Land Settlement Fund administered by the Land Settlement Fund Board of Trustees. The board is responsible for the provision of access to land for, among other things, conservation. Any monies appropriated by Parliament for the purposes of the fund must be paid into the fund, as also funds provided by bilateral or multilateral donors for the purpose of the fund; gifts, grants, donations or endowments as may be given to the board for the purpose of the fund; monies that may be borrowed by the board for the purposes of the fund; the rates, charges, dues or fees levied by the board of the Land Settlement Fund Trustees under this Act; all monies derived from the payment made by beneficiaries of settlement schemes; and such sums as may be payable to the board of the Land Settlement Fund Trustees pursuant to this Act or any other written law.

\subsubsection{Land Regulations}

The Land Regulations, 2017, deal with the management and administration of public, private and community land. An application for subdivision, amalgamation, partition and reparcellation of freehold land is submitted to the county government and is processed and approved in accordance with the laws relating to physical planning. ${ }^{468}$ The county government ascertains the viability of the subdivision, amalgamation, partition and reparcellation and, in that regard, seeks representations from the relevant authorities including, but not limited to, an officer representing the national director of Surveys at the county; an officer representing the national director of Physical Planning at the county; the land administration officer of the national government at the county; representative of the Land Control Board, where applicable; and any other relevant authority. ${ }^{469}$ An application for subdivision, amalgamation, partition and reparcellation of leasehold land is submitted to the county government. ${ }^{470}$ The county government, before granting approval for subdivision, amalgamation, partition and reparcellation, seeks representations from the officer representing the national director of Surveys at the county; the officer representing the national director of Physical Planning at the county; the land administration officer of the commission and of national government at the county; the Land Control Board, where applicable; and any other relevant authority. ${ }^{471}$

467 Section 19.

468 Regulation 16(1).

469 Regulation 16(2).

470 Regulation 17(1).

471 Regulation 17(2). 
An application for building plans on leasehold land is submitted to the relevant county government. ${ }^{472}$ Where the county government has approved building plans or any other development on leasehold land, it communicates the approval to the cabinet secretary and the commission for purposes of noting that the conditions of the lease have been met. $^{473}$

5.4.6.3 Guidelines for management of public land held by public agencies, statutory bodies and state corporations

Public agencies, statutory bodies and state bodies vested with the control, care and management of reserved land under Section 16 of the Land Act are required to carry out their mandate in accordance with the guidelines set out in the First Schedule of the Land Regulations. ${ }^{474}$ The guidelines stipulate that the institutions undertake to prepare long-term land-use and management plans for the land and deposit the plans with the commission.

\subsubsection{Community Land Act, 2016}

The Community Land Act ${ }^{475}$ provides for the recognition, protection and registration of community land rights; management and administration of community land; and the role of county governments in relation to unregistered community land. The Act establishes community land management committees, whose functions and powers include responsibility for the running of the day-to-day functions of the community; management and administration of registered community land on behalf of the respective communities; coordination of the development of community land-use plans in collaboration with the relevant authorities; promotion of cooperation and participation among community members in dealing with matters pertaining to registered community land; and prescribing of rules and regulations, to be ratified by the community assembly; and governing of operations of the community. ${ }^{476} \mathrm{~A}$ registered community must have a community assembly, which consists of adult members of the community. ${ }^{477}$ The quorum for decision-making by the community must not be less than twothirds of the community assembly. ${ }^{478}$ The community assembly must elect between

472 Regulation 20(1).

473 Regulation 20(2).

474 Regulation 5.

475 No. 27 of 2016.

476 Section 15(4).

477 Section 15(1).

478 Ibid. 
seven and 15 members of the community assembly to constitute the community land management committee. ${ }^{479}$ Provisions in the Community Land Act outlined below provide an opportunity to embed sustainable soil management.

\subsection{Land use and development planning of community land}

A registered community may, on its own motion or at the request of the county government, submit to the county government a plan for the development, management and use of the community land administered by the registered community, for approval. ${ }^{480}$ Before submitting a plan to the county government, a registered community must consider any conservation, environmental or heritage issues relevant to the development, management or use of the land; incorporate in the plan a statement that it has considered those issues when drawing up the plan; consider any environmental impact plan pursuant to existing laws on environment; comply with the values and principles of the Constitution; seek ratification from the members of the registered community; and be bound by any approved relevant physical development plan. ${ }^{481}$ If a registered community submits a plan to the county government and the government approves and notifies the registered community of that fact, the registered community must develop, manage and use the land concerned in accordance with the plan as approved or subsequently amended, as the case may be. ${ }^{482}$ The county government must, in considering a plan submitted to it, comply with the relevant law relating to development planning. ${ }^{483}$ The county government needs to, on request of the commission, submit records of development plans lodged with the county government in accordance with this section. ${ }^{484}$

\subsection{Conservation and management of resources in community land}

For purposes of the sustainable conservation of land-based natural resources in community land across counties, every respective registered community must abide by the applicable laws, policies and standards on natural resources. ${ }^{485}$ The communities must establish measures to protect critical ecosystems and habitats; incentives for communities and individuals to invest in income-generating natural resource conservation

479 Section 15(3).

480 Section 19(1).

481 Section 19(2).

482 Section 19(3).

483 Section 19(4).

484 Section 19(5).

485 Section 20(1). 
programmes; measures to facilitate the access, use and co-management of forests, water and other resources by communities who have customary rights to these resources; procedures for the registration of natural resources in an appropriate register; and procedures for the involvement of communities and other stakeholders in the management and utilisation of land-based natural resources. ${ }^{486} \mathrm{~A}$ registered community must put in place measures necessary to conserve resources on community land. ${ }^{487}$

\subsection{Grazing rights}

A registered community must take the customs and practices of pastoral communities relating to land into consideration as long as they are consistent with the provisions of this Act or other applicable law. ${ }^{488}$ Community land in a pastoral community must be available for use by members of the community for the grazing of their livestock, subject to such conditions as the respective registered community may impose, including conditions relating to the kind and number of livestock that may be grazed; the section or sections of the land where livestock may be grazed and the grazing in rotation on different sections; a grazing plan; and the right of the community to utilise the portion of land in accordance with this Act. ${ }^{489}$ This is an important provision, as overgrazing is one of the causes of soil degradation on rangelands. The registered community may, upon application by any person who is not a member of the registered community, grant grazing rights and, upon such grant, that person must exercise the rights subject to the conditions mentioned. ${ }^{490}$ The registered community must, subject to the approval of the members of the registered community in a meeting convened for that purpose, withdraw a grazing right if, owing to drought or any other reasonable cause, the registered community considers such cancellation to be in the interest of the residents of the community concerned. ${ }^{491}$ In addition, a registered community may withdraw the grazing right of any member who fails to observe in a material respect any condition or contravenes the provision of the Act. ${ }^{492}$

A person may not, except with the written authority of the registered community, erect or occupy any building or other structure on the designated grazing land; plough or cultivate any portion of the land; take up abode on or occupy any portion of the grazing land; or obstruct the access to any watering place on the land, prevent or attempt to prevent any person from drawing water from, or watering stock at a watering

486 Section 20(2).

487 Section 20(3).

488 Section 28(1).

489 Section 28(2).

490 Section 28(3).

491 Section 28(4).

492 Section 28(5) 
place, pollute the water at a watering place or interfere with the operation of any windmill, water-pump, water-pipe, dam or storage tank or other appurtenance installed or constructed at such a watering place. ${ }^{493}$

\subsection{Land use rights on community land}

A registered community may reserve special purpose areas including farming areas; settlement areas; community conservation areas; access and rights of way; cultural and religious sites; urban development; or any other purpose as the community, county government or national government may determine for the promotion of public interest. ${ }^{494}$ An area designated for special purposes must be used exclusively for the designated purposes. ${ }^{495}$

\subsection{Natural resources on community land}

Natural resources found on community land must be used and managed sustainably and productively for the benefit of the whole community, including future generations; with transparency and accountability; and on the basis of equitable sharing of accruing benefits. ${ }^{496}$

\subsection{Rules and by-laws}

A registered community may make rules or by-laws for regulating the management and administration of its land. Such rules or by-laws may provide for the regulation of investments in the land; the determination of terms of any leases granted for purposes of investment; the conservation and rehabilitation of the land; land use and physical planning; and any other relevant matter. ${ }^{497}$

\subsection{Regulation of community land-use planning}

The state has the power to regulate the use of any land, or interest in or right over land, in the interest of defence, public safety, public order, public morality, public health or

493 Section 28(6).

494 Section 29(1).

495 Section 29(2).

496 Section 35.

497 Section 37. 
land-use planning. ${ }^{498}$ The management of community land is subject to national and county government laws and policies relating to fishing, hunting and gathering; protection of animals and wildlife; water protection, securing sufficient residual water, hydraulic engineering and safety of dams; forestry; environmental laws; energy policy; and exploitation of minerals and natural resources. ${ }^{499}$

\subsubsection{Land Control Act}

The Land Control Act, Cap 302, regulates the development, use and subdivision of agricultural land. It establishes the Land Control Board for the land control area or division in which the land is situated, which must grant consent for any of the following transactions:

- The sale, transfer, lease, mortgage, exchange, partition or other disposal of or dealing with any agricultural land which is situated within a land control area.

- The division of any such agricultural land into two or more parcels to be held under separate titles, other than the division of an area of less than 20 acres into plots in an area to which the Development and Use of Land (Planning) Regulations, 1961 (L.N. 516/1961), for the time being, apply.

- The issue, sale, transfer, mortgage or any other disposal of or dealing with any share in a private company or cooperative society which, for the time being, owns agricultural land situated within a land control area. ${ }^{500}$

In deciding whether to grant or refuse consent in respect of a controlled transaction, a land control board must have regard for the effect which the grant or refusal of consent is likely to have on the economic development of the land concerned or on the maintenance or improvement of standards of good husbandry in the land control area. In addition, the land control board must act on the principle that consent ought generally to be refused where the terms and conditions of the transaction (including the price to be paid) are markedly unfair or disadvantageous to one of the parties to the transaction, or, in the case of the division of land into two or more parcels, the division would be likely to reduce the productivity of the land. ${ }^{501}$

Although the required consent is an excellent tool for soil conservation, the land control boards have not been as effective as they could be. Their activities have been marred by corruption with 'consent to the highest bidder' being the operative principle. On several occasions, the government has been forced to disband boards. ${ }^{502}$ 


\subsubsection{Physical and Land Use Planning Act, 2019}

The Physical and Land Use Planning Act repealed the Physical Planning Act of 1996 in a bid to conform to the Constitution of Kenya, 2010. As pointed out above, the Constitution of Kenya, 2010, created two levels of government and distributed specific functions to each of the governments. ${ }^{503}$ Section 3 of the Act outlines the objectives of the Act including to provide for principles, procedures and standards for preparation and implementation of physical and land-use development plans at the national, county urban and rural levels; to provide for the administration and management of physical and land-use planning in Kenya; and to provide a framework for equitable and sustainable use, planning and management of land, among others. Under the Act, all state organs, state officers and public officers engaged in regulation of land use or physical planning are bound by the Constitution and, in particular, are required to abide by the national values articulated under Article 10 of the Constitution, which includes sustainable development, as well as Article 60 of the Constitution, which provides sustainable land use as one of the principles of land policy. Some of the principles of physical and land-use planning articulated in Section 5 of the Act are that development activities must be planned in a manner that integrates economic, social and environmental needs of present and future generations.

Under Section 6 of the Act, a National Physical and Land Use Planning Consultative Forum is established, whose functions include: providing a forum for consultations on the national physical and land-use development plan and promoting effective coordination of planning, among other functions. Section 9 of the Act also requires the National Land Commission to monitor and oversee land-use planning throughout the country; prepare reports on the status of land-use planning in the country and present such reports to the President and Parliament; and develop a monitoring framework and oversight parameters for land-use planning. The cabinet secretary of matters relating to land is, on the other hand, vested under Section 10 of the Act with various responsibilities including: formulation of a national policy on physical and land-use planning; approval and oversight over the preparation of national physical and land-use development plans; issuance in the Kenya Gazette policy statements, guidelines and circulars on general and specific aspects of physical and land-use planning; and coordination of national and county levels of physical and land-use planning.

Cooperation of both the national and county governments is inextricably linked to the proper harmonised formulation of policies, management, development and planning of land. ${ }^{504}$ One pillar of devolution in the Kenyan set up is to ensure increased public participation in the management of county affairs at every stage of decisionmaking. This mandates the planning authority to develop plans and only invite 
objections to an already developed plan. ${ }^{505}$ In Article 10 and indeed as an object of devolution, the public must be involved in the formulation of such development plans for effective plans to be achieved. Participation should be in good faith and substantial, as opposed to tokenism. These contributions must be considered. ${ }^{506}$ The procedure for application and approval of development does not envisage public participation. ${ }^{507}$

The office of the Director of Physical and Land Use Planning is established under Section 13 of the Act and is given powers to: prepare national physical and land-use plans; prepare development plans for strategic national installations and projects; formulate policies, guidelines and standards relating to physical and land-use planning; coordinate the preparation of inter-county physical and land-use development plans; and advise the government on these matters, among other functions. Section 18 of the Act also establishes a county director of Physical and Land Use Planning for each county, who performs similar roles but at the county level. Furthermore, at the devolved unit level, the counties, a County Physical and Land Use Planning Consultative Forum has been established under Section 14 of the Act. This forum is tasked to operate in each county and has similar functions to the national forum.

There is a requirement in Section 21 of the Act to have national physical and landuse development plans, which cover an implementation period of 20 years and may be reviewed every 10 years. It is precisely this development plan that forms the basis for environmental conservation, protection and improvement, which include soil conservation and protection. Section 24 of the Act further provides that such plans must include a situation analysis of the state of physical and land-use development in the country and the various relevant studies and reports that may have been done. A spatial analysis - accompanied by physical, land use and suitability maps and charts that focus on soil, among other aspects of the environment - is required, as spelt out in the Second Schedule to the Act regarding the outline and format of local physical and land-use development plans.

Sections 57 and 58 of the Act requires a person wishing to make developments on their land to obtain development permission from the respective county executive committee member by applying for development permission, upon payment of the necessary fees. This is a means of development control - it is a right of the state to regulate the use of land as provided for under Article 66 of the Constitution. The purpose of development control is to ensure economic land use by allocating the resources to maximise benefits. ${ }^{508}$ Soil protection easily falls within this mandate. Article 60 requires that land be managed in an equitable, efficient, productive and sustainable manner. In addition, the use of land should ensure sustainable, productive, transparent

505 Section 9.

506 Robert N. Gakuru \& Others v Governor Kiambu County \& 3 others [2014] eKLR.

507 Section 33.

508 Mativo (2015). 
and cost-effective management of land. Article 10 contains principles such as social justice, equality, inclusiveness, integrity and sustainable development. These are binding principles that should be adhered to in land planning.

Kenya has had physical planning laws that have not been effective in the management of land. The main challenges bedevilling land planning in Kenya have been disregard of planning, and multiple land tenure regimes that create loopholes, conflicts and contradictions. ${ }^{509}$ Corruption, political patronage, weak institutions, and ineffective development control institutions have also affected land-use planning. In addition, the repealed Physical Planning Act was not clear on the classification of land use, particularly in mixed developments in residential areas. ${ }^{510}$ The Act was inflexible and unresponsive to the dynamics of development. In this regard, the law did not have effective regulatory mechanisms to deal with rapid urbanisation, population pressure and emergent land development dynamics, such as sectional properties.

This has led to indiscriminate extension of urban boundaries in areas of land which are still used predominantly for farming and livestock-keeping. Indeed, the land use in Kenya's urban areas does not conform to existing zoning and building regulations. Agricultural lands have rapidly been converted into concrete jungles and industries have sprung up in areas zoned for agriculture. ${ }^{511}$

The 2019 Physical and Land Use Planning Act has addressed some of these issues. Effective implementation of the Act will contribute to sustainable soil management. Of concern, however, is the failure of the Act to address the duplication and parallel setting up of institutions in the county government and national government. This is likely to continue to affect sustainable soil governance.

\subsubsection{Agriculture, Fisheries and Food Authority Act, 2013}

The Agricultural, Fisheries and Food Authority Act ${ }^{512}$ establishes the agriculture and food authority and makes provision for the respective roles of the national and county governments in agriculture, excluding livestock. The agriculture and food authority is established to promote best practices in, and regulate, the production, processing, marketing, grading, storage, collection, transportation and warehousing of agricultural products as may be provided for under the Crops Act, No. 16 of $2013 .{ }^{513}$ It is also mandated to collect and collate data, maintain a database on agricultural products, document and monitor agriculture through registration of players, as provided for in the

509 Ibid.; Institute of Social Accountability (2017).

510 Mativo (2015: 37).

511 Ndegwa (2001).

512 No. 13 of 2013.

513 Section 4(b). 
Crops Act. ${ }^{514}$ In addition, the authority is responsible for determining the research priorities in agriculture and to advise generally on this research. ${ }^{515}$

\subsubsection{Development, preservation and utilisation of agricultural land}

In regard to policy on development, preservation and utilisation of agricultural land, The cabinet secretary, on the advice of the authority, and in consultation with the National Land Commission, is empowered to provide general guidelines, referred to as land development guidelines, which are applicable to all categories of agricultural land. ${ }^{516}$ The land guidelines are to be implemented by the respective county governments, taking into account the circumstances of the respective areas under their jurisdiction. ${ }^{517}$ The guidelines may require the adoption of such system of management or farming practice or other system in relation to the land in question, including the execution of such work and the placing of such things in, on or over the land as may be necessary for the proper development of land for agricultural purposes. ${ }^{518}$

\subsubsection{Rules on preservation, utilisation and development of agricultural land}

The cabinet secretary is empowered on the advice of the authority, and in consultation with the National Land Commission, to make general rules for the preservation, utilisation and development of agricultural land. ${ }^{519}$ The rules may prescribe the manner in which owners, whether or not they are also occupiers, should manage their land in accordance with rules of good estate management; prescribe the manner in which occupiers should farm their land in accordance with the rules of good husbandry; advise on the control or prohibition of the cultivation of land or the keeping of stock or any particular kind of stock; advise on the kinds of crops which may be grown on land; provide controls on the erection of buildings and other works on agricultural land; and provide for such exemptions or conditional exemptions from the these provisions as may be desirable or necessary for vulnerable groups, including women. ${ }^{520}$

An owner of agricultural land is deemed to fulfil his or her responsibilities to manage the land in accordance with the rules of good estate management if, having regard for the character and situation of the land and other relevant circumstances, it enables

514 Ibid.

515 Section 4(b).

516 Section 21(1).

517 Section 21(2).

518 Section 21(3).

519 Section 22(1).

520 Section 22(2). 
an occupier of the land reasonably skilled in husbandry to maintain efficient production of kind, quality and quantity of produce. ${ }^{521}$ The occupier of agricultural land is deemed to fulfil his or her responsibilities to farm the land in accordance with the rules of good husbandry if the occupier is maintaining a reasonable standard of production, as regards both the kind of produce and the quality and quantity thereof, while keeping the land in a condition which enables this standard to be maintained in the future. ${ }^{522}$

\subsubsection{Soil conservation}

Section 23(1) of the Agriculture, Fisheries and Food Authority Act provides that the cabinet secretary, on the advice of the authority and in consultation with the National Land Commission, may prescribe national guidelines for the purposes of the conservation of the soil and the prevention of the adverse effects of soil erosion on any land. The guidelines may address any of the following matters:

- Prohibit, regulate or control the undertaking of any agricultural activity, including the firing, clearing or destruction of vegetation when such prohibiting, regulating or controlling is deemed by the cabinet secretary to be necessary for the protection of land against degradation and the protection of water catchment areas or otherwise, for the preservation of the soil and its fertility.

- Require, regulate or control the afforestation or re-afforestation of land in respect of the drainage of land, including the construction, maintenance or repair of drains, gullies, contour banks, terraces and diversion ditches; and salination, acidification and saltification of soil.

- Require the uprooting or destruction, without payment of any compensation therefor, of any vegetation which has been planted in contravention of a land preservation order.

- Require the supervision of unoccupied land.

- Prohibit, restrict or control the use of land for any agricultural purpose excluding livestock.

The guidelines may provide for such exemptions or conditional exemptions from the operation thereof as may be specified. The guidelines may also provide for the granting of permits or conditional permits of exemption from the operation thereof, its application to certain periods or seasons of the year, restricting its application to specified persons or any class or description of person, or to any area or areas, and requiring or prohibiting any act or thing to be done to or in respect of any land, notwithstanding 
that the purpose of such a rule or order or its carrying into effect is or will be to the benefit of any other land or land in the ownership or occupation of another person. ${ }^{523}$

\subsubsection{Crops Act, 2013}

The objective of the Crops Act ${ }^{524}$ is to accelerate the growth and development of agriculture in general, enhance productivity and incomes of farmers and the rural population, improve the investment climate and efficiency of agribusiness, and develop agricultural crops as export crops that will augment the foreign exchange earnings of the country. Landowners and lessees of agricultural land, being stewards, have the obligation to cultivate the lands they own or lease and make the land economically productive in a sustainable and environmentally friendly manner. ${ }^{525}$

\subsubsection{Irrigation Act, 2019}

The Irrigation $\mathrm{Act}^{526}$ is an act of Parliament to provide for the development, control and improvement of irrigation schemes, and for incidental and connected purposes. Section 3 of the Act establishes the National Irrigation Board, which is responsible for the development, control and improvement of national irrigation schemes in Kenya. ${ }^{527}$ The cabinet secretary may, after consultation with the board, make regulations generally, which may provide for the standards of good husbandry and the control of pests and diseases in national irrigation schemes. ${ }^{528}$ The regulations may also provide for the methods of harvesting, collection, storage, transport, processing, marketing and sale of produce grown on national irrigation schemes..$^{529}$

In this regard, the cabinet secretary promulgated the Irrigation (National Irrigation Schemes) Regulations, 1977. Any person who resides in, carries on business in, or occupies any part of the scheme, or grazes any stock thereon must, unless he is the holder of a valid licence granted to him under the regulations by the manager in charge of an irrigation scheme with the approval of the committee or is the authorised dependent of the licensee, be guilty of an offence. ${ }^{530}$ One of the conditions for granting the licence is that a licensee must comply with all instructions given by the manager with

523 Section 23(2).

524 No. 16 of 2013.

525 Section 4(b).

526 No. 14 of 2019.

527 Section 15(1).

528 Section 27(1)(b).

529 Section 27(1)(e).

530 Regulation 4. 
regard to good husbandry; the branding, dipping, inoculating, herding, grazing or watering of stock; the production and use of manure and compost; the preservation of the fertility of the soil; the prevention of soil erosion; the planting, felling, stumping and clearing of trees and vegetation; and the production of silage and hay. ${ }^{531}$ Any licensee who refuses, or without reasonable excuse fails, to comply with any of the conditions of the regulation must, in addition to any penalty that may be imposed, be liable to have his licence terminated by the cabinet secretary. ${ }^{532}$ A licensee may not construct buildings or other works of any kind on his holding or elsewhere in the scheme without the prior consent, in writing, of the manager and, in the event of his having erected a structure or building without such consent, the manager may direct, in writing, that the structure be removed and the land returned to its original state; and, if the licensee fails to comply with this direction within one month, the manager may enter the building or structure for the purpose of demolition and any expenses incurred by the manager for the removal of the building or structure may be recovered from the licensee. ${ }^{533}$ The requirement to restore the land to its original state implies that the licensee should undertake remedial action to redress soil degradation.

The Irrigation Act also prohibits the use of any prohibited chemicals or substances in the schemes. As previously observed, substandard fertilizers, chemicals and polluted water are illegally used in some irrigation schemes in Kenya. This points to ineffective implementation of the law.

\subsubsection{Plant Protection Act, 2012}

The Plant Protection $\mathrm{Act}^{534}$ provides that the Minister may make rules for preventing and controlling attacks by or the spread of pests or diseases on plants. ${ }^{535}$ Consequently, the act indirectly assists in soil protection by protecting crop cover, which is essential for preventing soil erosion.

\subsubsection{Mining Act, 2016}

The Mining Act ${ }^{536}$ applies to minerals specified in the First Schedule of the Act. The Act does not to apply to petroleum and hydrocarbon gases. ${ }^{537}$ A mineral right or other

531 Regulation 8(1)(f).

532 Regulation 8(3).

533 Regulation 10(5).

534 Cap. 324 of 2012.

535 Section 3.

536 No. 12 of 2016.

537 Section 3. 
licence or permit granted under this Act must not exempt a person from complying with any law concerning the protection of the environment. ${ }^{538}$ A mining licence will not be granted to a person under the Act unless the person has obtained an environmental impact assessment licence and social heritage assessment, and the environmental management plan has been approved. ${ }^{539}$

\subsubsection{Land use}

Section 179 of the Mining Act stipulates that the holder of a permit or licence under the Act is required to use the land in accordance with the terms of the permit or licence and should ensure the sustainable use of land through restoration of abandoned mines and quarries; that the seepage of toxic waste into streams, rivers, lakes and wetlands is avoided and that disposal of any toxic waste is done in the approved areas only; that blasting and all works that cause massive vibration is properly carried out and muffled to keep such vibrations and blasts to reasonable and permissible levels in conformity with the Environmental Management and Co-ordination Act; and that upon completion of prospecting or mining, the land in question must be restored to its original status or to an acceptable and reasonable condition as close as possible to its original state.

\subsubsection{Requirement of site restoration and mine-closure plans}

The cabinet secretary will not grant a prospecting licence, a retention licence or a mining licence to an applicant, unless the applicant has submitted site mitigation and rehabilitation, or mine-closure plans for approval. ${ }^{540}$ The cabinet secretary may prescribe regulations for site rehabilitation and mine-closure obligations. ${ }^{541}$

\subsubsection{Environmental protection bonds}

An applicant for a prospecting licence, a retention licence or a mining licence must provide a bond or some other form of financial security, called an environmental protection bond, sufficient to cover the costs associated with the implementation of the environmental and rehabilitation obligations of the holder under the Mining Act. $^{542}$ The required environmental protection bond must be in a form and for an amount as 
may be determined by the cabinet secretary, having regard for the particular characteristics of the project. ${ }^{543}$ In determining the form and amount of the bond, the cabinet secretary will take into account the amount that the applicant is required to provide by way of a bond or some other form of financial security under the provisions of the Environmental Management and Co-ordination Act. ${ }^{544}$ The cabinet secretary may release, in part, an environmental protection bond upon the satisfactory completion of rehabilitation measures undertaken within the duration of a licence and may release the bond in full following the successful completion of all environmental and rehabilitation obligations. ${ }^{545}$ In the case of soil pollution, the environmental protection bond may be used to restore and rehabilitate the soil.

As observed above, Kenya has large deposits of minerals. Under the Mining Act, a holder of a mining licence should observe environmental conditions and environmental laws. As highlighted in the $M u i^{546}$ case, mining companies do not always carry out EIAs before mining operations begin. It is important to note that most of the mining operations in Kenya are small scale, artisanal and informal. As such, the majority of the small-scale miners do not obtain mining licences. For instance, the artisanal gold mining areas of western Kenya have reported high soil pollution as miners continue to use metals such as mercury and lead illegally in gold prospecting. ${ }^{547}$

The Petroleum Act $^{548}$ provides a framework for the contracting, exploration, development and production of petroleum. It also provides the framework for the cessation of upstream petroleum operations and gives effect to relevant articles of the Constitution in so far as they apply to upstream petroleum operations, and regulation of midstream and downstream petroleum operations.

A person with whom the national government concludes a petroleum agreement is required to carry out upstream petroleum operations in the contract area in accordance with all the applicable environment, health, safety and maritime laws and best petroleum industry practices. ${ }^{549}$ The contractor should deploy the best available technology to ensure quality, environment, health and safety requirements are met; control the flow and prevent the waste or escape in the contract area of petroleum, gas (not being petroleum) or water; prevent the escape in the contract area of any mixture of water or drilling fluid and petroleum or any other matter; prevent damage to petroleum-bearing strata in any area in respect of which the petroleum agreement is not in force; prevent the pollution of any soil, air, biodiversity, brine, water well, spring, stream, river, lake, reservoir, sea, forest, wildlife and marine, estuary or harbour by the escape of

543 Section 181(2).

544 Section 181(3).

545 Section 181(4).

546 Constitutional Petition No. 305 of 2012.

547 Odinga (2018).

548 No. 2 of 2019.

549 Section 59(1). 
petroleum, salt water, drilling fluid, chemical additive, gas (not being petroleum) or any other waste product or effluent; and, where pollution occurs, treat or disperse it in an environmentally acceptable manner. Finally, a contractor must furnish to the authority, prior to the drilling of any well, a detailed report on the technique to be employed, an estimate of the time to be taken, the material to be used and the safety measures to be employed, in the drilling of the well. ${ }^{550}$ A contractor must ensure that the management of production, transportation, storage, treatment and disposal of waste arising out of upstream petroleum operations are carried out in accordance with all the applicable environmental, health, safety and maritime laws and best petroleum industry practices. ${ }^{551}$

A contractor and any other participant in upstream petroleum operations must, at all times maintain efficient measures for emergency preparedness with a view to dealing with incidents which may lead to loss of life or personal injury, pollution or damage to property. ${ }^{552}$ The contractor must ensure that the measures taken to prevent or reduce harmful effects include measures to ensure that the environment is restored as far as possible to its original condition prior to commencement of operations. ${ }^{553}$

The cabinet secretary is obligated to establish a disaster preparedness, prevention and management unit within the Ministry to coordinate response to accidents, disasters and other emergencies that may occur in upstream petroleum operations. ${ }^{554}$ The disaster preparedness, prevention and management unit should collaborate with the National Disaster Operations Centre, county governments and other relevant institutions to ensure a timely response and emergency preparedness for resource sharing. ${ }^{55}$ The cabinet secretary must formulate and periodically update a risk assessment of upstream petroleum operations and implement appropriate risk mitigation programmes. ${ }^{556}$ The disaster preparedness, prevention and management unit must in liaison with the contractor carry out public awareness and sensitisation forums for local communities resident in areas surrounding ongoing upstream operations. ${ }^{557}$ Where an accident or an emergency occurs, the contractor or other person responsible for the operation and use of the facility must, to the extent necessary, suspend the upstream petroleum operations for as long as the requirement of prudent operations warrants. ${ }^{558}$ Where special circumstances exist, the cabinet secretary may order that upstream petroleum operations 
be suspended to the extent necessary, or may impose particular conditions to allow continuation of the activities. ${ }^{559}$

A person who wishes to undertake refining, importation, export, bulk storage or transportation of petroleum crude or products must have a valid licence issued by the Energy Regulatory Commission. ${ }^{560}$ The licencing authority must, in granting or rejecting an application for a licence or permit, take into consideration the need to protect the environment and to conserve the natural resources in accordance with the environmental laws, maritime laws and international maritime treaties ratified by Kenya and other guidelines developed by the commission. ${ }^{561}$ A licence or permit issued by the licencing authority needs to set out a requirement that the licensee must comply with all applicable environmental, health and safety laws. ${ }^{562}$ An application for a licence must be accompanied by an environmental liability policy as may be prescribed by the authority. ${ }^{563}$

\subsubsection{Liability for damage}

The contractor is liable for damage from pollution, without regard to fault from whichever source, related to the upstream petroleum operations of the contractor when the damage occurs in Kenya or within its territorial waters. ${ }^{564}$ A person engaged in the petroleum business must comply with the applicable environmental, health and safety laws. ${ }^{565}$ In the event of a fire, explosion, oil spill, injury or fatality occurring in the course of operating a petroleum logistics facility, transportation or sale of petroleum, either by accident or through negligence, the operator or person transporting or selling the petroleum must forthwith clean up the polluted or damaged environment, at the operator's own expense, to the satisfaction of the licencing authority and any other relevant authority. Any person engaged in the storage, transportation or sale of petroleum and petroleum products must have an oil clean-up plan in compliance with the National Oil Spill Policy, relevant environmental health and safety regulations or guidelines. ${ }^{566}$ If the operator or person transporting or selling petroleum fails, or unreasonably delays, to carry out the work, the licencing authority may cause any work not carried out to be executed at the expense of the operator or person transporting or selling the petroleum. ${ }^{567}$

559 Section 71(2).

560 Section 74(1).

561 Section 75(1)(b).

562 Section 76(2).

563 Section 79.

564 Section 72.

565 Section 97(1).

566 Section 97(2).

567 Section 97(3). 


\subsubsection{Environment and Land Court Act, 2011}

The 2010 Constitution established a specialised court to deal with the environment and land. The promulgation of the Environment and Land Court Act ${ }^{568}$ illustrates the importance of land and natural resources in Kenya. This court has been in existence for close on nine years. Much time was spent defining the jurisdiction of the court and its relationship with the High Court. Cases revolving around jurisdiction bogged down the court for a while, slowing the rate at which it delivered judgements on land, land planning, land use and environmental protection. The court has also been under-staffed considering the preponderance of land and environment matters requiring adjudication. ${ }^{569}$ While many applicants for posts in the court are well versed with land matters, as this is a required course in all law schools, the number of lawyers with environment and land competence remains low. This denies the court a much-needed specialisation. These factors have indirectly contributed to environmental degradation because of the slow rate at which environmental and land-use disputes are resolved.

\subsubsection{Fertilizers and Animal Foodstuffs Act}

The Fertilizers and Animal Foodstuffs Act ${ }^{570}$ establishes the Fertilizer and Animal Foodstuffs Board of Kenya, whose functions include ensuring that fertilizers imported, manufactured or distributed in Kenya meet the standards of quality and safety prescribed by law. ${ }^{571}$ It also prohibits the importation, manufacture, compounding, mixing, or sale of any fertilizer or animal foodstuff that is not approved.

As was observed in Chapter two, the majority of the soils used for agriculture in Kenya require constant replenishing of nutrients. The application of substandard fertilizers has greatly contributed to soil degradation. Smuggling of substandard fertilizers into Kenya is sometimes carried out in collusion with government institutions. ${ }^{572}$

\subsection{Jurisprudence on environmental protection}

The courts of law in Kenya have attempted to interpret the various provisions of the law and the Constitution discussed in the foregoing section. The jurisprudence emanating from these decisions indicates that the courts are ready and willing to give effect to environmental principles and sustainable development. In this section, we review

568 No.19 of 2011.

569 See https://bit.ly/3pp4W1f, accessed 6 November 2019.

570 Cap 345.

571 Fertilizers and Animal Foodstuffs Act, Section 2(A) and (B).

572 Afri Ventures (Kenya) Limited v Turbo Highway Eldoret Limited [2014] eKLR; Ombati (2018). 
select cases so as to illustrate how courts have understood the right to a clean and healthy environment as well as the various statutory and constitutional provisions, and how this has affected or has the potential to affect soil conservation and improvement.

\subsubsection{John Mutungu Waititu v China Wuyi (Kenya) Co. Limited [2018] eKLR}

In this case filed at the ELC in Nyahururu, the appellant (John Mutungu Waititu) brought an action against the respondent claiming, among other things, that the respondent had failed to restore his land after excavating soil, thus leaving his land vulnerable to soil erosion, especially since it was on a hilly slope. The appellant argued that under the one-year lease agreement, both parties had agreed that upon excavation of the murram on the appellant's land, the respondent would push back the topsoil to fill any hole that may have remained so as to leave the land as flat as possible. The respondent did not honour this agreement. The court found that the respondent had contributed to environmental degradation, which it defined at paragraph 79 of the decision as "deterioration of the environment through depletion of natural resources such as air, water and soil; the destruction of ecosystems and the extinction of wildlife". The appellant had contested the award of 200,000 Kenyan shillings by the lower court as damages to the appellant for the environmental damage, arguing that no amount of money could compensate for the environmental damage and asked the court to issue an environmental restoration order. The court agreed with the appellant, set aside the order for compensation and substituted it with an order compelling the respondent to restore the land by topping up the soil as had been agreed under the agreement.

\subsubsection{African Centre for Rights and Governance (ACRAG) \& 3 Others $v$ Municipal Council of Naivasha [2017] eKLR}

In this case, the petitioner lodged a constitutional petition at the ELC in Nakuru, arguing that the continued operation of a dumpsite near Naivasha was a constitutional violation of the right of the inhabitants to a clean and healthy environment. The court made its finding at paragraph 43 as follows:

After considering all issues, I think in my view, this court ought to make some orders, some of which ought to take place immediately and some of which can be graduated over time. The immediate step is of course to order the respondent, now the County Government of Nakuru, to engage personnel and measures to immediately collect all plastic bags littering the area and to ensure that on a daily and continuous basis, plastic bags will continue being put aside for incineration or other forms of destruction so that the area is not prone to these. The County Government of Nakuru, must also forthwith, if it intends to continue using the site as a dump, apply for the requisite licence from NEMA, as required by Sections 87 and 88 of EMCA and such application must be made within 14 days from today. If such application is made, NEMA must proceed to assess this application having in mind all requisite criteria, and either decline or permit it 
with the necessary conditions for operations. In assessing the application, I direct NEMA, to ensure that a thorough Environmental Impact Assessment is done, with a consideration of among other things, alternative sites; all necessary mitigation measures including fencing of the site, and annual auditing. The option of having a landfill other than an open dumpsite should also be considered, for a landfill is a more modern and less environmentally destructive method of waste disposal.

Justice Munyao Sila further ordered for the judgement to be served upon the cabinet secretary responsible for environment matters to consider issues of policy and compliance with proper solid waste management, among other matters.

\subsubsection{Martin Osano Rabera, John Ndungu Kinyanjui v Municipal Council of Nakuru, NEMA \& County Government of Nakuru}

In this case $\mathrm{e}^{573}$, the petitioners were residents of Nakuru living near Gioto waste disposal site. They sought a declaration that their right to a clean and healthy environment under Article 42 of the Constitution of Kenya 2010 had been violated. In his judgement, Ohungo J. observed that the obligation to ensure a clean and healthy environment was for everybody - from the state to all persons be they of natural or juridical association or of another group of persons, whether incorporated or not. ${ }^{574}$ The court found that while the 2 nd respondent had a statutory mandate to offer technical support on environmental matters in Kenya, including waste disposal, the primary obligation in waste disposal and management rested with the county governments ${ }^{575} \mathrm{He}$ found for the petitioners. This case lays out the principle under the Fourth Schedule of the Constitution which makes it the responsibility of county governments to deal with all waste management.

\subsubsection{Moffat Kamau \& 9 Others $v$ Aeolus Kenya Limited \& 9 Others (the Kinangop Wind Park Project case)}

In this case, ${ }^{576}$ a company called Ecogen sought to have a wind power park in Kinangop area initially for the production of up to $30 \mathrm{MW}$ of power from turbines to be located in a single parcel of land. The company applied for and was issued with an EIA licence. This licence was later transferred to Aeolus Limited. Aeolus upscaled the project to $61 \mathrm{MW}$ and the project coverage was expanded from $2 \mathrm{sq} \mathrm{km}$ to $16 \mathrm{sq} \mathrm{km}$. To continue with this project, Aeolus did not apply for a new EIA licence, nor did it

573 Petition No. 53 of 2012 eKLR.

574 Ibid at para. 49.

575 The Judgement at para. 47

576 Nakuru ELC Petition No. 13 of 2015 (2016) eKLR. 
conduct a new EIA. Instead, it applied for, and was granted a variation of the original EIA licence without the necessity of conducting a fresh EIA. The petitioners successfully challenged this. The court held that where there was a substantial change in the character of the project, a variation of the original licence, which without a fresh EIA, was wrongful. The court held that where circumstances exist that would entitle NEMA to cancel the original licence, then NEMA must at least seek a fresh EIA before issuing a variation. In this instance, the court felt that the character of the project had changed so fundamentally that it was wrong for NEMA to only issue a variation of the original EIA licence, without a fresh EIA being conducted. The court also pointed out situations when it would be wrong for NEMA to only vary a licence without requiring a fresh EIA, including a change in the site of the project, a change in law, a change in technology to be used, or a change in the environmental effects. ${ }^{577}$

\subsubsection{John K. Kibicho \& Others (suing on behalf of the Milimani Residents Welfare Association) $v$ County Government of Nakuru \& Others}

The residents of Milimani in Nakuru, through their association, filed a suit to oppose the construction of a multiple storey residential block of flats in an area that predominantly consisted of bungalows. The evidence showed that the developer had applied for a change of user, which was opposed by the plaintiff but, despite this opposition, the county government of Nakuru (sued as the 1st respondent) gave the go-ahead for the development without giving the petitioners a hearing.

The court held that a change of use of land was applied for because the intended use of the land was not in conformity with the conditions attached to the holding of the title, and thus it was among the applications that needed to be served on owners or occupiers of adjacent land. A further notice also needed to be placed in the Kenya Gazette, in two local dailies, and a notice served upon the chief as required by Section 41 of the Physical Planning Act. In the case at hand, there was only one advertisement in one English daily newspaper, and the court was of the view that the provisions of the Physical Planning Act had not been complied with. The court cancelled the change of user licence. ${ }^{578}$

577 Ibid.: para. 85 .

578 See also Koome Mwambia \& Others suing on behalf of Kunde Road Residents Association v Deshun Properties Company Limited \& 4 Others, Nairobi ELC Petition No. 1433 of 2013 (2014) eKLR. 


\subsubsection{Justus Irungu Githae \& 12 Others v Attorney General \& 4 Others ${ }^{579}$}

In this case, an injunction was issued against the county government of Kirinyaga, stopping it from dumping waste on land that was neighbouring that of the petitioners who argued that the county government's action of dumping waste in their neighbourhood threatened their right to a clean and healthy environment. The county government conceded in their reply that they had not conducted any EIA before starting to dump waste and the court was of the view that any further dumping should be stopped pending the hearing of the petition.

\subsubsection{Joseph Leboo \& 2 Others v Director Kenya Forest Service \& Another}

The plaintiffs in this case complained about the issuance of licences for the felling of trees in Lembus Forest by the Kenya Forest Service (KFS). They complained that KFS had illegally allocated pre-qualified and unqualified saw millers to harvest timber and fuel materials from the Lembus Forest, without involving the community, in accordance with the law governing the harvesting of timber and firewood from forests. They also complained that the saw millers were harvesting trees that had not been allocated to them and were also harvesting unspecified trees. The court found that indeed there was no management plan for the forest despite this being an explicit requirement in the Forest Act, $2005 .^{580}$ The rules required a five-year management plan for every forest $^{581}$ and also barred KFS from issuing any authorisation without a site-specific plan in place. ${ }^{52}$ These were found to be lacking and the court issued an injunction stopping any further harvesting of trees.

\subsubsection{Raycon Limited v Superply Limited \& 2 Others ${ }^{583}$}

The plaintiff claimed to have been granted harvesting rights over exotic timber in the Mau Forest by KFS. The plaintiff claimed that the 1st and 2nd defendants had encroached on its allocated portion and were harvesting trees illegally and thus sought an injunction against the first and second defendants to stop them from any further harvesting of trees pending the hearing of the suit. It emerged in the course of the hearing that the plaintiff did not in fact have any licence to harvest trees, and yet had been allowed to harvest trees by KFS. The court also wondered how the 1st and 2 nd

579 ELC at Kerugoya, Case No. 804 of 2013 (2016) eKLR.

580 The Forest Protection and Sustainable Management Rules in the Forest Act, 2005.

581 Ibid.: Rule 5(1).

582 Ibid.: Rule 5(6).

583 ELC at Nakuru, Case No. 39 of 2017 (2017) eKLR (ruling of Sila J). 
defendants were allowed to harvest timber despite clear provisions in the Forest Act of 2016 barring the harvesting of trees in a forest without a licence. ${ }^{584}$ The court was not persuaded that either the plaintiff or the 1 st and 2 nd defendants had any licence to harvest trees and issued summons to the director of KFS to explain why these companies were being allowed to harvest trees in the Mau forest.

\subsection{Conclusion}

Soil conservation in Kenya is incidental to land and environmental protection in general. An appraisal of the legal framework reveals that although Kenya has many laws that have an impact on soil conservation, the institutional weakness, poor state of implementation and corruption contribute to the laws' inefficiency. In addition, soil conservation has not been a key consideration in the development landscape.

The recent ranking of Kenya as a lower middle-income country, its rapid massive infrastructural development and population growth, as well as its strategic location as the East African region's business and transport hub, have placed increased pressure on the country's finite natural resources, including land. ${ }^{585}$ Population increase, uncontrolled urban sprawl and industrialisation continue to mount pressure on land and soil, contributing its degradation. ${ }^{586}$ Unfortunately, the law has not evolved fast enough to protect the natural resources, particularly the soil and its components, as more attention is diverted to production, thus relegating sustainability and conservation of soil to the back burner. Considering the analysis above, we recommend the tightening of loose ends in the implementation of laws and enhanced capacity-building and institutional coordination.

A review of the legal, policy and regulatory environment relating to soil protection and conservation reveals that there is indeed a legal basis for ensuring soil protection in Kenya. While there is no single legal framework that expressly provides for protection of soil, there are various policies, strategies, national statutes, national constitution, regional and international instruments that Kenya has ratified which all speak to the protection of soil and improvement of its fertility. Put differently, the law on soil protection and improvement in Kenya may be found in ad hoc and fragmented pieces of legislation and policy documents.

While this fragmented nature of the legal framework does not in and of itself rob the legal framework on soil protection of its potency and utility, it certainly takes away the much-needed focus, creates overlaps among various institutions, and does not

584 The Forest Conservation and Management Act, 2016, Section 64(1)(a), which makes it mandatory for one to have a licence before harvesting any trees in a forest and Section 64(2) which provides that it is an offence for any one to undertake those activities without a licence.

585 Mwanza (2019).

586 Mundia \& Murayama. (2010). 
establish clear responsibilities for particular institutions and individuals. There is potential for conflict among institutions or even dereliction of duty, as each institution expects the other to act. A single legal framework that speaks specifically and solely about the protection and improvement of soil as a component of the environment will signal more urgency, and the various players involved will tend to give such laws much more attention and resources to drive their implementation.

ELC has taken on the mandate of protecting the environment and has made bold decisions. ELC is evolving into a critical player in the sustainable management of Kenya's land and environment, as was envisaged under the Constitution. The court would definitely make decisions for sustainable soil management if such issues were brought before it. A specific soil law would elicit such causes from the citizenry and lead to a robust soil jurisprudence as is emerging in the case of the environment.

Soil protection has featured in Kenya's policy and law terrain from colonial times. Soil has indeed been addressed historically at the highest political levels. As pointed out at the outset, however, there is currently no specific law on soil protection in Kenya. There are many provisions dispersed in different laws that can be used to protect soil. But, with no specific law on soil protection and with the various existing laws focusing principally on other issues, soil may be neglected. This gives rise to the need to consolidate soil protection measures in a dedicated law incorporating the measures that have been used for soil protection over the years.

\subsection{Lessons learnt}

The Constitution of Kenya, 2010, recognises the right to a clean and healthy environment, which includes the right to have the environment protected for the benefit of present and future generations through legislative and other measures. Okpara is of the opinion that the right to a clean and healthy environment includes a habitable human environment with, among other things, clean water, and soil and air free from toxins or other hazardous matter that threaten human health. ${ }^{587}$ As such, the recognition of the right to a clean environment is of fundamental importance to soil conservation and protection, as is the realisation of other constitutionally recognised human rights, including the right to be free from hunger, to have adequate food of acceptable quality, and to have the highest attainable standard of health. This constitutional provision 
provides an excellent platform and tools to demand the protection and conservation of soil as part of the environment.

A related matter is that the Kenyan Judiciary in the post-2010 period has been progressive and has shown remarkable dedication to a holistic, purposeful constitutional interpretation and the willingness to enforce the right to a clean and healthy environment. First, the courts are increasingly recognising the interconnection between the right to a clean environment and other social economic rights. In Friends of Lake Turkana Trust $v$ Attorney General \& 2 Others, ${ }^{588}$ the court held that the right to life, dignity and economic and social rights are all connected and indivisible, and it cannot be said that one set of rights is more important than another. All these rights of necessity need to be observed for persons to attain a reasonable livelihood. Such a broad approach allows a multidisciplinary application of laws, creating a wider protection of human rights. Second, the courts have in their holistic interpretation of the right to a clean environment held that this right inherently proscribes pollution of the environment. ${ }^{589}$ Third, despite the uncertainty about which court between the High Court and the Environment and Land Court has the jurisdiction to rule on disputes on environmental law protection, there is a general consensus that either of the courts should interpret the right to environment as protecting all components of the environment to the fullest extent permissible in law. ${ }^{590}$ Fourth, the courts and tribunals have boldly ruled on controversial government-sponsored projects that have negative impacts on the environment. In Save Lamu \& 5 Others v National Environmental Management Authority (NEMA) \& Another, ${ }^{591}$ the National Environment Tribunal nullified an environment impact assessment licence because of inadequate public participation by the residents of Lamu on the environmental impact of the project. Evidently, the Judiciary has been in the forefront in the protection of the environment. Accordingly, the courts present a strategic opportunity to enforce the right to a clean environment in soil governance and protection.

Manifestly, Kenya contains a comprehensive and robust environmental protection and conservation legal framework, particularly the Environment Management and Coordination Act, 1999. Although, soil conservation has not attained the level and robustness of protection that other components of the environment have, such as water, air, forests and wildlife, there is room, in the little avenue provided, to advocate proper soil management and protection within the broader ambit of the environment.

As previously noted, Kenya's soil profile and types require constant replenishing with nutrients. Accordingly, ideal soil legislation in Kenya should provide for standard fertilizers and chemicals of high quality that do not contribute to soil degradation. In

588 Friends of Lake Turkana Trust v Attorney General \& 2 others [2014] eKLR.

589 Pastor James Jessie Gitahi \& 202 Others $v$ Attorney General [2013] eKLR.

590 Said Tahir \& 2 others $v$ County Government of Mombasa \& 5 others [2015] eKLR.

591 Save Lamu \& 5 others $v$ National Environmental Management Authority (NEMA) \& another [2019] eKLR. 
this regard, Kenya has in place the Fertilizers and Animal Foodstuffs Act that establishes the Fertilizer and Animal Foodstuffs Board of Kenya, whose functions include ensuring that fertilizers imported, manufactured or distributed in Kenya meet the standards of quality and safety standards prescribed by law.592 It also prohibits the importation, manufacture, compounding, mixing, and selling of any fertilizer or animal foodstuff that is not approved. Similarly, there is the Irrigation Act, 2019, which prohibits the use of any chemicals or substances unapproved for use in the schemes. As previously observed, wastewater and substandard chemicals are often used illegally in Kenya.

The Kenyan land tenure system recognises the private, public and community land systems. It behoves the government as the custodian of public land and in the interest of the public to conserve and protect the soils of public land. Specifically, Article 69 obligates the state to ensure that there is sustainable exploitation, utilisation, management and conservation of the environment and natural resources, and equitable sharing of the accruing benefits. On private land, Article 66 gives the state and the police powers to control use of the land for public benefit. Notably, Kenya, an inherently communal society, now has the opportunity to collectively and collaboratively conserve the environment and soils within community lands as part of Kenyan African heritage.

Access to information on environment and soil, in particular, is of utmost importance in soil conservation and protection. First, given that Articles 22 and 70 of the Constitution give every person the right to approach the court to enforce human rights, access to information remains a vital component of this right. Second, courts have been consistent that adequate, timely and accessible information and awareness are critical elements of participatory governance. Article 35 of the Constitution provides the right of access to information held by the state, as well as information held by another person and required for the exercise or protection of any right or fundamental freedom. In Friends of Lake Turkana Trust v Attorney General \& 2 Others [2014] eKLR, the court held that "it is also now an accepted principle in international law that such access to environmental information is necessary to meet the goals of sustainable development". Kenya has the Access to Information Act, 2016, whose legislation provides for mechanisms for access of information. Evidently, the right to access to information as a component of soil conservation and protection is well protected in Kenyan laws. Unfortunately, there is still inadequate and out-dated information that lacks geographical contextual analysis.

Sustainable soil management requires an integrated approach that builds on both local and natural resources with appropriate use of targeted inputs and management practices. There is a need to quantify the costs of land degradation so that it becomes feasible to assign a value to land degradation. Attributing a value to land degradation

592 Fertilizers and Animal Foodstuffs Act, Section 2(A) and (B). 
will also help policymakers to understand the benefits that would accrue from improvement of soil fertility and soil conservation in terms of improved food security. Doing this economic calculation would help to focus and reinforce attention on land degradation as a pressing policy challenge that requires urgent remedial action.

Environmental protection, including protecting the soils of Kenya, is compartmentalised and governed by sectoral laws. The sectoral pieces of legislation range from laws on land, air, water, environment, agriculture, forests and wildlife. Unfortunately, these laws do not adequately and effectively provide for soil-specific provisions. Instead, soil governance, protection and conservation have become secondary or an incidental aspect of environmental protection. This has led to relegation of soil conservation and little attention has been paid to its conservation.

Despite the inadequate soil-specific provisions in the sectoral laws highlighted above, each of the pieces of legislation creates an institutional framework to implement and enforce the specific legislation. For instance, the National Environment Management Authority established under the Environment Management and Coordination Act, 1999, is the lead agency in environmental protection; the Agriculture and Food Authority Act establishes the Agriculture and Food Authority to implement the Crops Act, 2013; the Irrigation Act, 2019, establishes the National Irrigation Authority to implement the Irrigation Act; and the Fertilizers and Animal Foodstuffs Act establishes the Fertilizer and Animal Foodstuffs Board of Kenya to oversee the standards of fertilizers imported or manufactured in Kenya, among other institutions. However, as was noted in Chapter four of this report, the National Land Use Policy recognises that there has been inadequate institutional coordination, and this impedes soil conservation and protection.

Related to inadequate institutional coordination is the uncertainty surrounding the scope of county and national government roles, as contained in the Fourth Schedule of the Constitution. As was highlighted in Chapter two and three of this report, there have been conflicts between the national government and county government on the scope of each level of government's responsibility in agriculture. While the Constitution devolves actual implementation of agricultural activities to county governments, the national government has been reluctant to fund and devolve agricultural activities. In addition, both levels of government have established parallel institutions in the agricultural sector, which creates conflicts and duplication of roles leading to blame games and inefficiency in soil protection and agriculture in general. ${ }^{593}$

Despite the various environmental laws in Kenya that would protect the soil, these laws are poorly implemented. In the earlier sections of this report, we gave instances where illicit trading has led to smuggling of substandard fertilizers in huge volumes, despite the existence of the Fertilizer and Animal Foodstuffs Board of Kenya, Kenya

593 County Government of Migori \& 4 others v Privatization Commission of Kenya \& another [2017] eKLR. 
Bureau of Standards, an overzealous Kenya Revenue Authority Custom Department, the National Cereals Board, and the Directorate of Criminal Investigations, among other notable institutions. Similarly, environmental impact assessment licences are rarely obtained before the commencement of mega projects that have negative impacts on soil and, if obtained, they are irregularly issued.

Regarding the National Environment and Management Authority, there have been challenges in this institution's enforcement mechanism as other lead agencies do not cooperate or enforce environmental laws in their respective divisions. In respect of irrigation, we highlighted instances of use of wastewater in irrigation schemes, which then pollute the soil despite clear legal provisions. On land planning and urban sprawl, corruption has invaded the developmental control departments in the country and the planning laws are rarely followed. Cumulatively, the omissions, inactions and actions by various stakeholders have led to soil degradation.

On access to information as a powerful tool to soil conservation, we have observed elsewhere that soil information in Kenya is generally outdated and inaccessible. The inadequate information, particularly to farmers, sees the continued practice of unsustainable agricultural activities that pollute the soil.

Processes such as urbanisation have contributed to degradation of agricultural soils, in particular; thus, threatening food security. The nature, extent, severity and degree of soil degradation varies and changes, based on location, community, and use to which the particular land is put. This therefore requires specific measures based on the vulnerability of each soil. For instance, counties such as Kitui, Machakos and Makueni, which receive little to no rainfall and which have sandy soil, among other types of soil, are more susceptible to erosion and therefore require more stringent measures to avert continued degradation.

There are also linkages between soil degradation and poverty, particularly among the rural poor who depend mainly on the productivity of soil for their livelihood. As such, any efforts to improve the economic lot of the people and eradicate poverty must encompass reforms geared towards improving soil fertility and ensuring soil protection.

On climate, Kenya is quickly positioning itself as a world leader in green economy and clean energy. However, and as observed earlier in this report, there have not been efforts to conserve the soils, given that loss of soil carbon contributes to climate change.

A significant level of consideration of the political context of any particular society is critical if there are to be any successful legal and policy reforms. This is largely because much of policy and legislative reforms turns on the political goodwill that may be afforded to any such legislative initiatives by the executive and parliamentary arms of government, which almost invariably comprise politicians. In particular, all policy documents originate from the Cabinet, which is part of the Executive, and are then taken to Parliament for adoption. Equally, only the legislative assemblies (Parliament 
and County Assemblies) are vested with the exclusive legislative authority. The Executive represented by the President has the power to assent to all bills passed by Parliament, essentially giving the bills the force of law. Similarly, various delegated pieces of legislation are usually the product of the executive branch of government, mainly the cabinet secretaries, who draft the regulations. Realisation of this fact then means that it is of significant moment to ensure the buy-in of politics as this is necessary to ensure that various proposals relating to soil conservation are transmuted into legislative proposals. It is not all legislative and policy proposals that are put forward or even desired in particular quarters that find expression in law. A lot depends on whether proposals secure the goodwill and support of politicians in Parliament and the Executive.

The upshot of the foregoing is that a political economy analysis in any particular society is necessary if there are to be successful legislative and policy reforms. Attempts to construe legislative reforms to ensure soil conservation and prevention of soil degradation as merely technical rather than a political process is bound to fail. It is essential that these changes be viewed within their wider political context and that an assessment of the various incentives that face all the various stakeholders be done. Some of these stakeholders, including Parliament, Executive, Ministry of Agriculture, county governments, farmers, agricultural officers, and agrochemical industries, have various and sometimes conflicting interests that must be considered if reforms are to be successful. Where particular stakeholders' interests are not considered or views of particular stakeholders are ignored, there is usually a tendency for such groups of stakeholders to create hindrances to successful reforms. A large part of the success that may be experienced in reforms geared towards enhancing soil conservation depends on engagement with counterparts in government.

In addition, a lack of appreciation of the political context or the lack of buy-in by politicians is likely to lead to challenges in implementation of laws and policies geared towards ensuring soil protection. This is partly because politicians head the Executive, which will be responsible for implementing laws that call for soil conservation. Deployment of the financial and technical resources necessary for ensuring the implementation of laws that promote soil conservation is similarly largely dependent on the goodwill of politicians in charge of the relevant department within the Executive and Parliament.

In our view, a detailed analysis of the underlying motivations of the key actors and institutions within the soil sector is an imperative for successful legislative reforms. A proper understanding of these motivations and incentives of the various stakeholders and institutions will help those in charge of pushing for a soil law to manage their interests and expectations and lobby them so as to garner their much-needed political support. For instance, given the strong linkage between soil fertility and agricultural output and the need for food security among the electorate, this may be framed in such a manner that the politicians become aware that soil conservation is a politically live 
issue that can form a campaign issue - so much so that issues of soil conservation and improving soil fertility form part of the agenda of politicians even as they go and seek out the support of the electorate. Moreover, in Kenya the President has set out an ambitious target of meeting four main agendas, one of which is food security. Yet, food security is impossible in the absence of improved soil fertility and the control of soil degradation. Massive resources are being allocated and considerable attention is being paid to measures that can ensure the achievement of food security. In these circumstances, there is hardly a better opportunity for lobbying for a soil-specific soil law in Kenya than during this period.

\subsection{Recommendations}

In view of the foregoing and the contents of this report, the following recommendations are made with respect to enhancing soil conservation and protection in Kenya: There is a need for the country to develop a comprehensive soil policy which brings together all stakeholders to develop the principles and policies to govern soil management in Kenya. At the national level, the country should in a participatory manner enact comprehensive soil legislation that implements the principles of soil conservation and management in Kenya. With the devolution of agriculture as a function of county governments under the Fourth Schedule of the Constitution, county assemblies should also development county-specific legislation on soil management and governance. This will assist in the development soil legislations that are specific to soils in various regions.

In developing soil conservation measures, given the cross-cutting role of soil, there is a need to develop an integrated approach and to legislate having regard to other important components of the environment. Moreover, there is a need to set out clearly the roles of the national and county governments and create institutions. To avoid an uncoordinated institutional framework, there is a need to have harmonised institutional coordination.

In terms of enhanced enforcement of environmental laws and environmental rights it has also been noted that there is laxity in enforcement of laws by mandated institutions. It is therefore recommended that the National Environment and Management Authority and other institutions should coordinate and collaboratively implement environmental laws on protection and conservation of the soil. Soil being a cross-cutting natural resource, there is a need to create an integrated approach of enforcement to abolish the sectoral implementation of environmental laws. There is a need to enhance the penalties set out in law for breaches and introduce restoration taxes that should be paid by those guilty of degrading soils, over and above the restoration orders that may be ordered by courts or tribunals against such persons. In addition, there is a need to ensure that issues of sustainable soil management are inculcated into school-going 
learners by integrating this matter into the school or educational curriculum. Such a move would ensure that children and young learners become champions of soil management, similar to the efforts to integrate climate change awareness into school learning. The net effect of this is to cause young learners to be agents of soil protection, which would ensure that soil is protected for the forthcoming generations.

It is critical that updated information on the quality of soil is easily accessible to the general public, many of whom are small-scale farmers who depend daily on soil for their economic livelihood and sustenance. There is need to adopt various techniques such as afforestation and reforestation, and the use of low-cost technologies as these methods and techniques have the potential to improve soil protection. Some incentive schemes should be developed such as fertilizer and manure subsidies for local smallscale farmers who would otherwise ill-afford these nutrients as this would help improve soil fertility. There is a need to take a holistic approach to soil conservation in law by taking note of the fact that soil is degraded through a variety of ways and means, including through erosion, acidification, salinisation, compaction, contamination, and loss of nutrients and organic matter. Any attempt to prevent soil degradation and improve the status of soil through legislation must therefore encompass measures geared towards arresting the factors that result in soil degradation.

Policymakers ought to realise, while drafting soil legislation, that a number of activities including land-use changes, urban expansion, intensification of agriculture, particular farming methods, and deforestation result in biodiversity loss and soil degradation and thus need to be taken care of in law. There should be a recognition that issues relating to soil protection are transboundary in nature and that they should be independent of any political boundaries if they are to be handled successfully and effectively.

The enumerated recommendations could inform the legislation enacted to regulate soil. Below, we set out some of the key features or elements that should be contained in soil-specific legislation in Kenya.

\subsection{Elements of a soil-specific legislation}

There are various essential features or elements that a soil-specific law in Kenya should contain including the following: The purpose of the law be clearly stated and which should ideally be on the sustainable management of soils. The statement of purpose may speak about the need for a competent organisation charged with managing soils, setting of priorities, the geographical area of interest of the law, and areas of application of the law. A definitional section should provide definitions of various concepts to provide clarity as to the meaning of the words used and the context in which such words and phrases are employed. The objective of the law should be devoted to the conservation of soil, the prevention of soil degradation, and the improvement of soil 
fertility in order to ensure food security. The law should also contain principles that undergird its application on soil and which can serve as an interpretive guide to the courts in the event of conflicts over interpretation. Another section shall set out rights and responsibilities accruing to various parties and actors. This delineation of rights and responsibilities is important in ensuring accountability of functions. In terms of the protection of marginalised persons and communities it is essential that the law encompasses special provisions on the rights of marginalised groups, especially bearing in mind the critical role of soil for livelihood sustenance. It often happens that marginalised groups, which include the poor, women, and persons living in arid and semiarid areas that rarely experience adequate rainfall, suffer long periods of droughts and occasional flash floods, which result in soil erosion and degradation. The law should, therefore, make special provision to enhance soil conservation and soil fertility in these areas to ensure food security. In the section on national authorities and focal points the law should outline the institutional framework responsible for soil conservation and protection and necessarily comprising various ministries and state agencies charged with agriculture, land, water and irrigation, among others.

Regarding public and community participation the law should have provisions requiring involvement of the people (as the public or the community), given that it is the people who are most affected by the state of the soil. This is especially critical in constitutional democracies such as Kenya and would also be in conformity with the constitutional provision which lists public participation as a national value. The utility of this provision is that the views and insights of the public are captured and implemented for the better management of soils.

In the developmental interest of national soil strategies, the law ought to provide for the development of soil strategies at the national level, preferably by the ministry. These soil strategies should then act as a reference point for all the various actions that would be done. The law should provide for periodic reviews of the soil strategies to help the law align with changes that occur in the soil sector.

In determination of national soil authority, the law should preferably establish a national soil authority, which should be a state agency resourced by the national government. The soil authority should be the overarching body mandated with various functions including soil information, soil planning, executive and financial administration, and conducting of soil evaluation and assessment, among a variety of other functions. The authority should have a head, who will be the titular head and executive officer of the authority to ensure the achievement of its functions. The law should also establish a national soil advisory body which should also be devolved to the various counties. Principally, the advisory body should be made up of a group of high-level experts well-versed in soil science, agriculture, herbicides, crop science, land, physical planning and other related disciplines. The mandate of the advisory body should be to advise on legal, strategic, administrative, political and financial issues relating to the sustainable management of soils. The body would serve as the intellectual nerve centre 
and would be concerned with preparing, implementing and reviewing soil strategies and other policies relating to sustainable management of soils.

Linked to the national soil strategy is the need to develop a national soil policy, which may be reviewed every 10 years. The soil policy would encapsulate the main principles that should guide the management of soils and would precede any subsequent ruling on the subject of soil that may be enacted. The law should proscribe a list of activities. The prohibited or outlawed activities should be those that have a deleterious effect on soil. The power to punish for violation of this provision should be vested in the national soil authority.

Given the importance of conducting soil research and investigating developments to improve soil status, and the need to build the technical capacity of persons involved in the management of soil, there ought to be a provision in the law for these express mandates. For the effective and sustainable management of soils, the law ought to devise and provide for a monitoring framework that regularly assesses the state of soil, particularly in erosion prone areas. This kind of monitoring would then help the soil authority, and the government in general, to take corrective measures that are geared to restoring the health and fertility of the soil.

Soil protection, conservation, prevention of soil degradation, and improvement of soil fertility entail resource-intensive exercises that require a huge mobilisation of resources. This is especially so given the level and extent of land degradation in particular areas of the country. It is therefore critical that there be a guaranteed financing scheme from government. The law should make provision to deal with the right of citizens and other concerned persons to soil information. This would in essence be a restatement of the constitutional right to information. This right would ensure that the government is held accountable for all actions relating to soil and would ensure that it would seek to comply with the law. As soil degradation is transboundary in nature in that effects of soil erosion occurring in one country or county can spill over into the territory of another country or county, proper soil conservation will necessarily entail a coordinated approach that is cross-border in nature, and which seeks the support of other neighbouring countries and counties.

Women tend to be the managers within the household responsible for providing food to the family. Evidence shows that in most of sub-Saharan Africa it is the women who manage land and farms for subsistence, even in cases where they do not hold titles to the land. It therefore means that when soil is degraded, women are disproportionately harmed compared to men, as it is women who are charged with the duty of ensuring that there is food security in the household.

The legal framework on soil should have both a liability and redress mechanism. Such a framework would ensure that for each liability, there is a legal remedy that can be afforded to the injured party. The law should explicitly vest the National Environment Tribunal with the original jurisdiction to adjudicate disputes relating to soil, 
being an environmental matter, and decisions should be appealed before the Environment and Land Court to enable expeditious resolution of disputes.

\section{References}

Allan, C., 2008, 'Can adaptive management help us embrace the Murray-darling basin's wicked problems?”. In: Pahl-Wostl, C., P. Kabat \& J. Möltgen (eds), Adaptive and integrated water management, Berlin: Springer, 61.

Allan, O., 2019, "High Court orders closure of Kibos sugar factory over pollution". Citizen Digital 31 July 2019, at https:/citizentv.co.ke/news/high-court-orders-closure-of-kibos-sugar-factoryover-pollution-266894/ accessed 10 October 2019.

Bailey, T.A., 2018, "The curious case of substandard fertilizers in Kenya”. International Policy Digest 30 June 2018.

Bentsi-Enchill, K., 1964, An exposition, analysis and critique. London: Sweet \& Maxwell.

Bondi, D.O. \& J. Mugabe, 1996, "Land tenure systems and natural resource management". In: Calestous, J. \& J.B. Ojwang (eds), In land we trust: Environment, private property and constitutional change. Nairobi: Initiatives, 85.

Bragdon, S.H., 1990, Kenya's legal and institutional structure for environmental protection and natural resource management. Washington: Economic Development Institute of the World Bank, at http://documents.worldbank.org/curated/en/278671468774886535/pdf/multi-page.pdf, accessed 18 May 2019.

Commission of Inquiry, 2004, Report of the Commission of Inquiry into the illegal/irregular allocation of public land. Nairobi: Commission of Inquiry, at https://bit.ly/3prdvIB, accessed 15 February 2021.

Corray, M.S., 1978, “The Kenya Land Commission and the Kikuyu of Kiambu”. Agricultural History $52,179$.

David, P. \& C.A. Edwards, 1982, "Pesticides and Ecosystems". Issues in Biology Education Oxford University Press on behalf of the American Institute of Biological Sciences (32) 7, 595.

David, M., D. Ndirangu, M. Mangala, J. Boman, K. Shepherd \& M. Gichuru, 2016, "Environmental implications of high metal content in soils of a titanium mining zone in Kenya". Environmental Science and Pollution Research 23, 21431.

Gadgil, M., 1989, “On the diversification of common property”. In: Berkes, F. (ed.), Common property resources: Ecology and community-based sustainable development, 240.

Gichenje, H., J. Muñoz-Rojas \& T. Pinto-Correia, 2019, “Opportunities and limitations for achieving land". Land 8 (8), 115.

Gichuki, F.N., 1991, Environmental change and dryland management in Machakos district, Kenya 1930-1990 conservation profile. Working Paper 56, University of Nairobi, at https://www.odi.org/sites/odi.org.uk/files/odi-assets/publications-opinion-files/6951.pdf, accessed 18 May 2019.

Government of Kenya, 2002, National action programme: A framework for combating desertification in Kenya in the context of the United Nations Convention to Combat Desertification. Nairobi: Ministry of Environment and Natural Resources \& National Environment Secretariat.

Government of Kenya, 2009, National land policy. Nairobi: Ministry of Lands, at https://www.refworld.org/docid/5b3e29474.html, accessed 2 February 2021. 
Government of Kenya, 2013a, The state of the world's biodiversity for food and agriculture - Kenya report. Nairobi: Government of Kenya, at http://www.fao.org/3/CA3473EN/ca3473en.pdf, accessed 2 February 2021.

Government of Kenya, 2013b, National environment policy. Nairobi: Ministry of Environment, Water and Natural Resources, at https://bit.ly/37gN3LI, accessed 15 February 2021.

Government of Kenya, 2014, Kenya demographic and health survey. Nairobi: Government of Kenya. Government of Kenya, 2016a, National spatial plan 2015-2045. Nairobi: Government of Kenya.

Government of Kenya, 2016b, Report of the land degradation assessment (LADA) in Kenya based on a study of land degradation assessment (LADA) with remote sensing and GIS, for sustainable land management (SLM) in Kenya. Nairobi: Ministry of Environment and Natural Resources.

Government of Kenya, 2017a, The Big Four Agenda, at https://www.president.go.ke, accessed 18 January 2021.

Government of Kenya, 2017b, National land use policy. Nairobi: Ministry of Lands and Physical Planning, at https:/lands.go.ke/wp-content/uploads/2018/06/SESSIONAL-PAPER-NO.-1-OF2017-ON-NATIONAL-LAND-USE-POLICY.pdf, accessed 2 February 2021.

Government of Kenya, 2018a, Kenya integrated household and expenditure survey 2015/2016 basic report. Nairobi: National Bureau of Statistics.

Government of Kenya, 2018b, Kenya Vision 2030: Third medium term plan 2018-2022. Nairobi: Government of the Republic of Kenya, at http://vision2030.go.ke/wp-content/uploads/2019/01/THIRD-MEDIUM-TERM-PLAN-2018-2022.pdf, accessed 1 February 2021.

Government of Kenya, 2018c, Taskforce report on forest resources management and logging activities in Kenya. Nairobi: Government of Kenya.

Government of Kenya, 2019a, Kenya population and housing census. Volume I: Population by county and sub county Nairobi: National Bureau of Statistics.

Government of Kenya, 2019b, Kenya population and housing census. Volume III: Distribution of population by age and sex. Nairobi: National Bureau of Statistics.

Government of Kenya, Royal Netherlands Government \& UNEP, 1997, National land degradation assessment and mapping in Kenya. Nairobi: Government of Kenya.

Hannam, I. \& B. Boer, 2004, Drafting legislation for sustainable soils: A guide. Gland: IUCN.

Herbling, D., 2019, "Kenya to double debt ceiling to almost match economy's size". Bloomberg News 16 October 2019, at https:/www.bloomberg.com/news/articles/2019-10-16/kenya-to-doubledebt-ceiling-to-almost-match-economy-s-size, accessed 1 February 2021.

Howard, T.M. \& A. Lawson, 2015, "Soil governance: Accessing cross-disciplinary perspectives". International Journal of Rural Law and Policy 1, 3776.

Huxley, E., 1935, White man's country: Lord Delamere and the making of Kenya. London: Macmillan and Co., Limited.

Institute of Social Accountability, 2017, Memorandum on Physical Planning Bill 2017, at https://www.tisa.or.ke/images/uploads/Memorandum_on_the_Physical_Planning_Bill_2017.pdf accessed November 2019.

Kabau, T. \& C. Njoroge, 2011, "Application of international law in Kenya under the 2010 Constitution: Critical issues in the harmonisation of the legal system". Comparative and International Law Journal of Southern Africa 44 (3), 293.

Kabau, T.J.O. \& Ambani, 2013, "The 2010 Constitution and the application of international law in Kenya: A Case of migration to monism or regression to dualism?". Africa Nazarene University Law Journal 1(1), 36. 
Kakumu, O.A., 1996, The impact of land acquisition problems on plan project implementation. Thesis submitted in partial requirement of Master of Arts in Planning, University of Nairobi.

Kameri- Mbote, P., 2002, Property rights and biodiversity management in Kenya. Nairobi: ACTS Press.

Karanja, F., 2019, "Top KEBs officials in court seeking re-test of alleged substandard fertilizer". Standard Digital 9 January 2019, at https://www.standardmedia.co.ke/article/2001308784/topkebs-officials-seek-fresh-test-on-fertiliser, accessed 20 October 2019.

Karuku, G.N. \& INNSPUB / International Network for Natural Sciences, 2018, "Soil and water conservation measures and challenges in Kenya". Current Investigations in Agriculture and Current Research 2 (5), 259.

Kazungu, R., J. Gitau \& P. Gichuru, 2011, “Application of GIS in identification, documentation and monitoring Brownfield land". Paper presented at the 47th ISOCARP Congress 2011.

KASLMP / Kenya Agricultural Productivity and Sustainable Land Management Project \& Ministry of Environment and Natural Resources, 2016, Land degradation assessment in Kenya report. Nairobi: KASLMP, at http://www.environment.go.ke/wp-content/uploads/2018/08/LADA-LandDegradation-Assessment-in-Kenya-March-2016.pdf, accessed 1 February 2021.

Kenya National Bureau of Statistics, 2018, Economic Survey 2018. Nairobi: Kenya National Bureau of Statistics.

Kenya National Bureau of Statistics, 2019, Economic Survey 2019. Nairobi: Kenya National Bureau of Statistics.

Lugard, F.D., 1929, The dual mandate in British tropical Africa. London: W. Blackwood.

Maina, W., 2016, "Why dissolution of land control boards will not cure corruption, disbanding land boards won't end corruption". Daily Nation 24 June 2016, at https://mobile.nation.co.ke/blogs/dissolution-of-land-control-boards-will-not-cure-corruption/1949942-3266160-mklifp/index.html accessed 6th November 2019.

Mativo, J.M., 2015, The role of law in urban planning in Kenya: Towards norms of good urban governance. LLM Thesis, University of Nairobi.

Ministry of Foreign Affairs of Netherlands, 2018, Climate change profile: Kenya. The Hague: Ministry of Foreign Affairs, at https://www.government.nl/documents/publications/2019/02/05/climate-change-profiles, accessed 18 January 2021.

Ministry of Land and Urban Planning, 2017, Sector Plan for Population, Urbanization and Housing 2013-2017. Nairobi: Ministry of Land and Urban Planning.

Mohajan, H., 2014, "Food and nutrition scenario of Kenya". American Journal of Food and Nutrition 2 (2), 28.

Mulinge, W., P. Gicheru, F. Murithi, P. Maingi, E. Kihiu, O.K. Kirui \& A. Mirzabaev, 2016, "Economics of land degradation and improvement in Kenya". In: Nkonya, E., A. Mirzabaev \& J. von Braun, 2016, Economics of land degradation and improvement-A global assessment for sustainable development. Cham: Springer, 471.

Mundia, C.N. \& Y. Murayama, 2010, "Modelling spatial processes of urban growth in African cities: A case study of Nairobi city". Urban Geography 31 (2), 259.

Mungeam, G.H., 1966, British rule in Kenya, 1895-1912: The establishment of administration in the East Africa Protectorate. Oxford: Clarendon Press.

Munro, A.P., 1959, The land tenure revolution in Kenya 1954-1959: Legal and political implications. Master Thesis, Columbia University, at http://erepository.uonbi.ac.ke/bitstream/handle/11295/96147/A.P.\%20MUNRO\%20M.A\%201960.pdf?sequence=4\&isAllowed=y, accessed 18 May 2019. 
Mutisya, T., K. Juma \& L. Zejiao, 2010, "Soil and water conservation in Kenya-operations, achievements and challenges of the National Agriculture and Livestock Extension Programme (NALEP)". Journal of American Science 6 (3), 7.

Mutono, N.R., 2016, Environmental and health problems associated with artisanal mining in Kenya: A case study of Macalder mines in Migori. Master Thesis Environmental Governance, University of Nairobi.

Muyanga, M. \& J. Thomas, 2006, Agricultural extension in Kenya: Practice and policy lessons. Working Paper 26, Tegemeo Institute of Agricultural Policy and Development, Egerton University.

Mwanza, K., 2019, "Thousands of acres of farmland are being turned into satellite cities". How we made it in Africa 31 March 2019, at https://www.howwemadeitinafrica.com/thousands-of-acresof-kenyan-farmland-are-being-turned-into-satellite-cities/63097/, accessed 20 October 2019.

Namusyule, S. \& L. Mueni, 2018, "Impact of Judiciary budget cut". Judiciary 21 August 2018, at https://www.judiciary.go.ke/impact-of-judiciary-budget-cut/, accessed 1 November 2019.

National Environment Management Authority, 2011, Integrated national landuse guidelines. Nairobi: NEMA.

Ndegwa, E.N., 2001, "Making Kenya a planning society: Challenges and opportunities”. Paper presented during the Launch Workshop of the Kenya Institute of Planners held at Nairobi Safari Club on 8 March 2001, unpublished.

Nyabonyi, J., 2016, Suitability assessment of effluents from Mwea irrigation scheme for reuse in irrigation for rice production, Kirinyaga County, Kenya. Master Thesis Master of Sciene, Kenyatta University.

O'Connell, D.P., 1960, “The relationship between international law and municipal law”. Georgetown Law Journal 48 (3), 431.

Odinga, T., 2018, "Focus on miners, farmers as soil pollution rises". Business Daily 4 December 2018, at https://www.businessdailyafrica.com/datahub/3815418-4881226-11dxfl kz/index.html, accessed 3 November 2018.

Odote, C., 2013, "Kenya: The new Environment and Land Court". IUCN Academy of Environmental Law E-Journal 1.

Oduor, M., 2014, "The status of international law in Kenya". Africa Nazarene University Law Journal $2(2), 97$.

Ogemba, P. \& K. Muthoni, 2019, "Budget cuts: Treasury slashed Judiciary's budget by Sh3 billion”. Standard Digital 29 October 2019, at https://www.standardmedia.co.ke/article/2001347258/judiciary-on-trial-as-cash-crisis-hits-hard, accessed 1 November 2019.

Okpara, C.I., 2012, "Right to a clean and healthy environment: The Panacea to the Niger Delta struggle". Journal of Politics and Law 5 (1), 3.

Ombati, C., 2018, "Firm denies claims into fertilizer accusations amid KEBS arrests". Standard Digital 24 June 2018, at https://www.standardmedia.co.ke/article/2001285333/firm-denies-claimsinto-fertilizer-accusations-amid-kebs-arrests, accessed 6 November 2019.2

Osolo-Nasubo, N.A., 1977, Socio-economic study of the Kenya highlands from 1900-1970: A casestudy of the Uhuru government. Washington: University Press of America.

Owino, K. \& J. Mutua, 2019, “Analysis of trends in Kenya's public debt”. Presentation, Institute of Economic Affairs-Kenya 24 April 2019.

Palley, C., 1966, The constitutional history and law of Southern Rhodesia 1880-1965. Oxford: Oxford University Press. 
Salaudeen, A., 2019, "Kenya launches largest wind power plant in Africa". CNN Marketplace Africa 20 July 2019, at https://edition.cnn.com/2019/07/20/africa/africas-largest-wind-farm-intl/index.html, accessed 2 February 2021.

Shiundu, A., 2018, "Long road to Independence". Development and Cooperation 12 December 2018.

Swynnerton, R.J.M., 1954, A plan to intensify the development of African agriculture in Kenya. Nairobi: Government Printer.

Thurston, A., 1987, Smallholder agriculture in colonial Kenya: The official mind and the Swynnerton Plan. Cambridge: African Studies Center, at https://www.african.cam.ac.uk/images/files/titles/smallholder, accessed 17 May 2019.

UNCCD / United Nations Convention to Combat Desertification, 2016, Achieving land degradation neutrality at the country level: Building blocks for LDN target setting. Bonn: Global Mechanism of the UNCCD, at https://bit.ly/2M2Ks0C, accessed 26 October 2019.

UNDP / United Nations Development Programme, 2013, Combating desertification in Kenya: emerging lessons from empowering local communities. Nairobi: UNDP, at https://bit.ly/2N5u00b accessed 26 October 2019.

Wabwile, M., 2013, "The emerging juridical status of international law in Kenya”. Oxford University Commonwealth Law Journal 13 (1), 167.

Wasilwa, C. \& S. Nanjala, 2019, "Stop pollution or face legal action, MP tells firm - toxic waste disposal war nets 9, factories shut". Daily Nation 28 August 2019, at https://bit.ly/3bihHW8, accessed 6 November 2019.

Wolff, R.D., 1974, The economics of colonialism: Britain and Kenya 1870-1930. Yale: Yale University Press.

World Commission on Environment and Development, 1987, Our common future. Oxford: Oxford University Press. 
